\title{
Antioxidant Molecules from Plant Waste: Extraction Techniques and Biological Properties
}

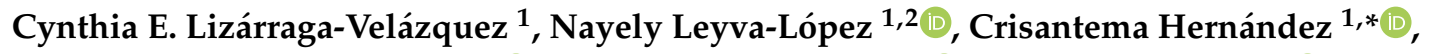 \\ Erick Paul Gutiérrez-Grijalva ${ }^{3}{ }^{\circledR}$, Jesús A. Salazar-Leyva ${ }^{4}{ }^{\circledR}$, Idalia Osuna-Ruíz ${ }^{4}{ }^{\circledR}$, \\ Emmanuel Martínez-Montaño ${ }^{5}(0)$, Javier Arrizon ${ }^{6}$, Abraham Guerrero ${ }^{1,2}{ }^{\circledR}$, \\ Asahel Benitez-Hernández ${ }^{7}(1)$ and Anaguiven Ávalos-Soriano ${ }^{1,2}(\mathbb{C}$
}

1 Centro de Investigación en Alimentación y Desarrollo, A.C., Av. Sábalo Cerritos S/N, S/C, Mazatlán C.P. 82112, Sinaloa, Mexico; cynthia.lizarraga@ciad.mx (C.E.L.-V.); nayely.leyva@ciad.mx (N.L.-L.); aguerrero@ciad.mx (A.G.); anaguiven.avalos@ciad.mx (A.Á.-S.)

2 Cátedras CONACYT-Centro de Investigación en Alimentación y Desarrollo, A.C., Av. Sábalo Cerritos S/N, S/C, Mazatlán C.P. 82112, Sinaloa, Mexico

3 Cátedras CONACYT-Centro de Investigación en Alimentación y Desarrollo, A.C., Carretera a Eldorado Km. 5.5, Col. Campo El Diez, Culiacán C.P. 80110, Sinaloa, Mexico; erick.gutierrez@ciad.mx

4 Maestría en Ciencias Aplicadas, Unidad Académica de Ingeniería en Biotecnología, Universidad Politécnica de Sinaloa, Carretera Mazatlán-Higueras km 3, Mazatlán C.P. 82199, Sinaloa, Mexico; jsalazar@upsin.edu.mx (J.A.S.-L.); iosuna@upsin.edu.mx (I.O.-R.)

5 Cátedras CONACYT-Maestría en Ciencias Aplicadas, Unidad Académica de Ingeniería en Biotecnología, Universidad Politécnica de Sinaloa, Carretera Mazatlán-Higueras km 3,

Mazatlán C.P. 82199, Sinaloa, Mexico; emartinez@upsin.edu.mx

6 Centro de Investigación y Asistencia en Tecnología y Diseño del Estado de Jalisco A.C., Unidad Zapopan, Camino Arenero 1227, El Bajio, Zapopan 45019, Jalisco, Mexico; jparrizon@ciatej.mx

7 Facultad de Ciencias del Mar, Universidad Autónoma de Sinaloa, Av. Paseo Claussen s/n AP 178, Los Pinos, Mazatlán 82000, Sinaloa, Mexico; asahelbenitez_facimar@uas.edu.mx

* Correspondence: chernandez@ciad.mx

Received: 28 October 2020; Accepted: 25 November 2020; Published: 28 November 2020

\begin{abstract}
The fruit, vegetable, legume, and cereal industries generate many wastes, representing an environmental pollution problem. However, these wastes are a rich source of antioxidant molecules such as terpenes, phenolic compounds, phytosterols, and bioactive peptides with potential applications mainly in the food and pharmaceutical industries, and they exhibit multiple biological properties including antidiabetic, anti-obesity, antihypertensive, anticancer, and antibacterial properties. The aforementioned has increased studies on the recovery of antioxidant compounds using green technologies to value plant waste, since they represent more efficient and sustainable processes. In this review, the main antioxidant molecules from plants are briefly described and the advantages and disadvantages of the use of conventional and green extraction technologies used for the recovery and optimization of the yield of antioxidant naturals are detailed; finally, recent studies on biological properties of antioxidant molecules extracted from plant waste are presented here.
\end{abstract}

Keywords: phytosterols; terpenes; phenolic compounds; bioactive peptides; extraction; valorization; fruit; vegetable; green technologies; residues

\section{Introduction}

According to the Food and Agriculture Organization of the United Nations [1], globally, agriculture produces 8.65 billion tons of food per year. Along the agricultural food supply chain, a large amount of waste of fruits, vegetables, cereals, and pulses is produced, mainly during post-harvest, processing, 
and household consumption [2,3]. The levels of agricultural waste vary from region to region. For example, the United States of America generates about 15 million tons of fruit and vegetable waste, while China generates 32 million tons [4]. Cereals waste represents 10-12\% of North America and Europe's total production, while Asia is up to $18 \%$ [5]. In Mexico, the processing of fruits, vegetables, and cereals generates about 76 million tons of waste per year [6].

The main agricultural wastes of peels, pomace, seeds, leaves, resin, and others are produced each year and are commonly disposed of in the environment, causing serious pollution and environmental problems. However, these wastes represent one of the main sources of low-cost antioxidants molecules, including terpenes, phytosterols, phenolic compounds, and peptides [7-10]. The antioxidant molecules could be used as food additives, pharmaceuticals, or therapeutic agents, because they have been shown to play an important role in the prevention and adjunctive treatment of diseases such as diabetes, cancer, hypertension, and metabolic syndrome [11-15].

Therefore, the revaluing of plant-derived waste is a topic of interest to the scientific community. The attention has been focused on studying the recovery technologies for antioxidant molecules, especially those that are friendly to the environment, also known as green extraction technologies or non-conventional technologies such as enzyme-aided extraction, ultrasonic and microwave-assisted extraction, pressurized liquid extraction, and supercritical fluid extraction. These green technologies have replaced conventional technologies such as maceration and hydrodistillation, due to their high yield, reduced extraction process time, and mild conditions that prevent or reduce the degradation of the antioxidant molecules maintaining their quality, but above all, because the compounds of interest are recovered from sustainable processes [16-18].

This review will briefly describe the main antioxidant molecules from plant-derived waste. Conventional and non-conventional extraction technologies using response surface methodology (RSM) and details about the parameters used to optimize the extraction process such as temperature, solvent, time, enzyme, frequency, pressure, and others are presented in detail. Studies in vivo and in vitro on biological properties of antioxidant molecules and their action mechanisms are reviewed.

\section{Plant Waste as Source of Bioactive Compounds}

Waste from inedible parts of plants such as peel, leaves, stem, seed, and root can be generated during the harvesting, post-harvesting, or processing [19]. They constitute a low-cost source of antioxidant molecules, including terpenes, polyphenols, phytosterols, and peptides, which exhibit antidiabetic, anti-obesity, antihypertensive, anticancer, and antibacterial properties [12,20-23]. However, these residues might have a negative impact on the environment. In this regard, as an effort to reduce the environmental consequences of plant waste and their potential exploitation, studies have focused on giving added value to plants waste through green extraction of antioxidant molecules, for intensifying their use as functional additives, or as a therapeutic alternative in the treatment or prevention of chronic diseases such as cardiovascular diseases, diabetes, and cancer [24].

Peels and pomace of fruits such as mango, apple, grape, pomegranate, pineapple, banana, and orange are the main waste of the agri-food industry, which might present a greater content of phenolic compounds than the edible portion $[19,25]$. On the other hand, the oil industry of almond, rapeseed meal, and coconut; the processing of cereals (mainly wheat, rice, and oat); and the pitting process of fruits such as olive, plump, tomato, and peach generate large amounts of protein-rich residues, which have recently been used for the production of bioactive peptides [9,26-33]. Terpenes have been extracted mainly from essential oils from leaves, resins, and cones of trees such as Pinus taeda, Pistacia lentiscus, etc. [34]. Oils from fruits (e.g., melon, mango, orange, berries, papaya, apple, passion fruit, and guava seeds) and cereals (e.g., wheat, oat, and rice) are generally known to be the best natural sources of dietary plant sterols known as phytosterols [35-37]. 


\section{Bioactive Compounds from Plant Waste}

The plant wastes contain a wide variety of bioactive compounds, including fiber, glucosinolates, saponins, terpenes, phenolic compounds, phytosterols, and peptides $[6,16,38]$. In this review, the main bioactive compounds with antioxidant activity will be briefly described below.

\subsection{Terpenes}

Terpenes are antioxidant molecules, also known as terpenoids o isoprenoids (Figure 1a) [8]. These compounds are formed by the condensation of two subunits of isoprene $\left(\mathrm{C}_{5} \mathrm{H}_{8}\right)$ (hydrocarbon with five atoms of carbon) [8,39]. According to the number of isoprene units (C5), terpenoids can be classified as shown in Table 1 [39-41].

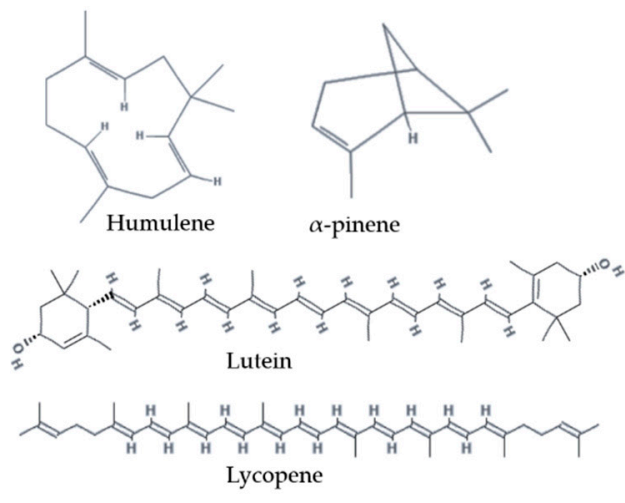

a) terpenes

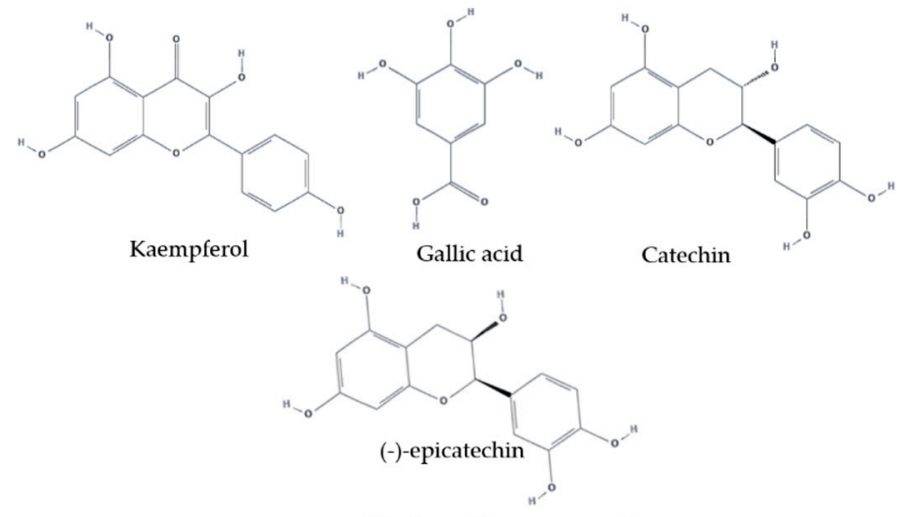

b) phenolic compounds

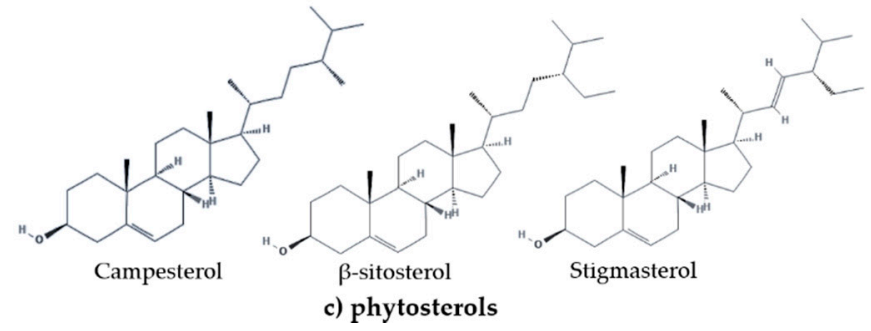

Figure 1. Chemical structure of (a) terpenes, (b) phenolic compounds, and (c) phytosterols. The structures were obtained from the PubChem database [42-52].

Table 1. Classification of terpenes according to the isoprene number.

\begin{tabular}{ccc}
\hline Terpenes (Classification) & Amounts of Carbons & Isoprene Units \\
\hline Hemiterpenoids & 5 & 1 \\
Monoterpenoids & 10 & 2 \\
Sesquiterpenoids & 15 & 3 \\
Diterpenoids & 20 & 4 \\
Sesterterpenoids & 25 & 5 \\
Triterpenoids & 30 & 6 \\
Tetraterpenoids & 40 & 8 \\
Politerpenoids & $>40$ & 8 \\
\hline
\end{tabular}

Terpenoids have antiviral, antifungal, antibacterial, anticancer [39,40,53-55], antihypertensive, gastroprotective, antitumor, cytotoxic [40], and anti-inflammatory properties [53,56-63]. Terpenes constitute $90 \%$ of essential oils and present a great diversity of structures and compounds, such as limonene, p-cymene, $\alpha$-pinene, and $\alpha$-terpinene (monoterpenes) and such as carvacrol, thymol, and camphor (oxygenated monoterpenes). The biological properties of terpenes are attributed to chemical structure. For example, the antioxidant activity is mainly due to phenolic-type components, 
such as linalool, thymol, carvacrol, and D-limonene [64,65]. The antimicrobial activity is related to hydrophobicity $[64,66,67]$, causing irreversible damage to the wall and membrane of bacterial cells, which leads to a leakage of proteins, DNA molecules, and RNA [68,69]. The immunomodulatory activity of monoterpenes has been related to their ability to modulate the serum immune parameters [70].

On the other hand, tetraterpenoids and sesquiterpenoids are other important groups of terpenoids. Carotenoids are the most representative group of tetraterpenes, which can be classified into two groups: xanthophylls (lutein, zeaxanthin, and $\beta$-cryptoxanthin) with the presence of oxygen in their molecules; and carotenes, which are hydrocarbon carotenoids without oxygen in their molecules such as $\alpha$-carotene, $\beta$-carotene, and lycopene (Figure 1a) [71]. Carotenoids can exhibit anti-cancer or immunostimulant effects, both associated with their antioxidant property [72,73], the latter related to the presence of their conjugated double bonds and the presence of ring structures at the end of the polyenes [74]. Sesquiterpenoids (C15H24) can be acyclic (Farnesol) or contain rings (bisabolol, curcumene, caryophyllene, humulene, valencene, sativene, selinene, and others) $[75,76]$. These compounds are recognized for their cytotoxicity effect on cancer cells, attributed to their antioxidant property [75]. Additionally, in vivo, sesquiterpenoids induce apoptosis in cancer cells [76].

\subsection{Phenolic Compounds}

Phenolic compounds are benzene molecules containing $\mathrm{OH}$ moieties (Figure $1 \mathrm{~b}$ ) produced as secondary metabolites by plants as a defense response against depressors or different stress conditions [77]. In nature, fruits, vegetables, cereals, chocolate, olive oils, and beverages such as tea and wine are considered rich sources of phenolic compounds [78]. In the scientific literature, around 8000 different phenolic structures have been reported, and more than a half correspond to flavonoids [79]. There are two types of phenolic compounds, the free phenolics (FP) and non-extractable phenolics (NEP), as FP, NEP are interesting as they exhibit antioxidant, antitumor, and anti-cholesterol properties, their difficult extraction is due to have a high molecular mass, or they are small phenolics linked to cellulose or hemicellulose, other polysaccharides, or polypeptide networks [77]. The NEP are classified in proanthocyanidins, hydrolyzable tannins, and complex tannins [77]. Free phenolics are classified in hydroxybenzoic and hydroxycinnamic acids, stilbenes, chalcones, and flavonoids.

Phenolic compounds have positive effects on human health on neurodegeneration restoring, aging, cancer, metabolic disorders such as diabetes, cardiovascular diseases, hypertension, and infections [80]. The anticancer and anti-inflammatory properties of phenolic compounds (anthocyanins, epigallocatechin-3-gallate (EGGC) and resveratrol) are related to their antioxidant (free radical scavengers) and pro-oxidant mechanisms. The antibacterial activity of phenolic compounds is related to the damage to the bacteria cell membrane. This process involves modifying the membrane permeability leading to the loss of cell wall integrity and changes in intracellular functions by enzyme binding, which is explained in detail below.

\subsection{Phytosterols}

Plant sterols are generally known as phytosterols. These are natural and bioactive compounds that represent a diverse group of triterpenes [37,81]. Humans do not synthesize phytosterols, so they must be obtained from dietary sources, such as plant-derived foods [81]; mainly in nuts, seeds, cereals and legumes [81,82], vegetable oils (corn oil, rapeseed oil (canola), soybean oil, and sunflower oil), vegetables [81], and products made with them.

The most important and abundant phytosterols are $\beta$-sitosterol (carbon structure C-29), campesterol (C-28), and stigmasterol (C-29) (Figure 1c) [37,81,82]. Furthermore, phytosterols have biological functions and chemical structures similar to cholesterol [83,84], except for an additional hydrocarbon chain at carbon 24 (C-24) [82,85]. Phytosterols differ from cholesterol by an extra methyl or ethyl group at C-24 or a double bond at the C22 position $[81,86]$. These changes in their structure make cholesterol and phytosterols functionally and metabolically different from each other [81]. 
Phytosterols can help human and animal health when these bioactive compounds are consumed regularly over time through natural foods or enriched foods [87]. Some of these benefits include improving serum lipid profile [85] and potentially reducing blood cholesterol levels [88]; additionally, they have antidiabetic, hepatoprotective, anticancer, antioxidant, antimicrobial, anti-inflammatory, antiatherosclerotic, and antitumor effects [37,83,85,87-89].

The reducing activity of phytosterols on cholesterol is due to their similar structure, since they can reduce cholesterol absorption in the small intestine [82,83]. Because they are more lipophilic than cholesterol, then phytosterols displace cholesterol from phospholipid micelles [83,87]. However, the absorption of phytosterols is lower than that of cholesterol due to selectivity and return to the intestinal lumen mediated by ABC transporters [83,87]. There is a very close relationship between the low absorption rate of different phytosterols and the carbon side chain's length. The absorption levels of campesterol, which has a methyl group, are higher than those of $\beta$-sitosterol, which possess an ethyl group [83].

\subsection{Bioactive Peptides}

There is extensive literature on the study of bioactive proteins, hydrolysates, and peptides isolated or produced from food plants. In contrast, there is scarce literature for compounds from plant waste [90], whose study has gained increasing interest, becoming a reuse and revalorization strategy while contributing to minimizing waste generation. Due to the compositional characteristics of plant waste, bioactive proteins have been modest compared to research on molecules such as phenolic compounds, vitamins, fatty acids, and pigments, among other groups no less interesting and important [91]. Bioactive peptides with antimicrobial, antihypertensive, and anti-inflammatory properties have been identified and isolated from fruits and vegetables [92,93].

Bioactive peptides properties depend on some structural characteristics such as length, amino acids composition, sequences, and charge. Bioactive peptides generally are small, composed of two to 12 amino acids. In the case of ACE-inhibitory peptides presence of Tyr, Phe, Trp, Pro, Lys, Ile, Val, Leu, and Arg has a strong influence; but for di- and tripeptides, the ACE-inhibitory activity is related to the presence of aromatic amino acids [94]. The antioxidant property of bioactive peptides is related to aromatic and hydrophobic amino acids, as well as acidic amino acids and their amide forms (Glu, Gln, Asp, and Asn) [29]. Instead, antimicrobial peptides normally have cationic and amphipathic molecules, facilitating the bond between the peptide and the cytoplasmatic membrane [93].

\section{Extraction Techniques for Recovery of Bioactive Compounds}

The use of green extraction techniques to obtain antioxidant molecules from waste has increased in recent years due to the current need for (i) mitigate the negative environmental impact and (ii) optimizing extraction techniques through the application of the RSM to increase the yield of production of bioactive compounds [16]. The main extraction techniques focused on optimizing the recovery process of antioxidant molecules are described below.

\subsection{Maceration and Hydrodistillation}

Maceration and hydrodistillation are conventional extraction technologies commonly used for the recovery of bioactive compounds [95-98]. The maceration is a technique based on the use of organic solvents, solid-to-solvent ratio, agitation, temperature, and time extraction [99-101]. This extraction technology involves a simple and inexpensive procedure; that is why it is still the most widely used $[99,102]$. However, the maceration technique presents the following disadvantages: (i) use of potentially toxic solvents, (ii) long periods of extraction, and (iii) requires a subsequent concentration process (usually evaporation) for the recovery of bioactive compounds [103]. Furthermore, the recovery yield of bioactive compounds using this technology is relatively low when compared to non-conventional technologies. For example, Safdar, et al. [104] reported that the recovery of phenolic compounds from kinnow shell (Citrus reticulate L.) was low (8.64 mg GAE/g) using extraction by 
maceration and $80 \%$ ethyl acetate as the solvent, in comparison with the recovery of phenolic compounds obtained by the ultrasound-assisted extraction (32.48 mg GAE/g) using the same solvent. Moreover, Kehili et al. [105] indicated that recovery of lycopene from tomato peel was higher $(728.98 \mathrm{mg} / \mathrm{kg})$ using supercritical fluid extraction (SFE) than with maceration $(608.94 \mathrm{mg} / \mathrm{kg}$ ) using hexane as solvent. Nevertheless, studies have been conducted to optimize the conditions for the extraction of bioactive compounds from vegetable waste using maceration. For instance, Anastácio, et al. [106] used the RSM and artificial neural network (ANN) models to predict the optimal conditions for the aqueous extraction of phenolic compounds from sweet potato peels. The optimal extraction conditions found with the RSM and ANN model were identical (temperature: $75^{\circ} \mathrm{C}$, time: $30 \mathrm{~min}$, solvent(water)-to-solid ratio: $60 \mathrm{~mL} / \mathrm{g})$. These settings allowed to obtain a total phenolic content of $11.87 \pm 0.69 \mathrm{mg}$ GAE $/ \mathrm{g}$ and antioxidant capacity of $12.91 \pm 0.42 \mathrm{mg}$ TE/g and $46.35 \pm 2.71 \mathrm{mg}$ TE/g measured by ABTS and DPPH assays, respectively. The authors mention that these optimal parameters show potential to obtain antioxidant aqueous extracts from sweet potato peel and might add value to this waste. Furthermore, Alrugaibah et al. [107] evaluated the efficiency of different natural deep eutectic solvents (NDES) to obtain procyanidins and anthocyanins from cranberry pomace. The NDES selected to procyanidin and anthocyanin extraction were (i) one consisting of choline chloride:betaine hydrochloride:levulinic acid (1:1:2) (NDES2) and (ii) one consisting of glucose:lactic acid (1:5) (NDES8), respectively. The RSM model for obtention of procyanidins by NDES 2 under the optimal conditions (50 mL NDES2/100 mL water, time: $30 \mathrm{~min}$ and solid-to-solvent ratio: 1:40) had R2 $=0.977$, which was comparable to artificial neural networking $(\mathrm{R} 2=0.973)$; these parameters achieved a yield of $34.83 \mathrm{mg}$ procyanidin $/ \mathrm{g}$ was achieved. The ANN model for extraction of anthocyanins using NDES 8 under the optimal conditions (50 mL NDES 8/100 mL water, time: $10 \mathrm{~min}$, solid-to-solvent ratio 1:20) performed better than RSM model ( $\mathrm{R} 2=0.95$ for ANN versus 0.88 for RSM); these settings achieved a yield of anthocyanins of $1.30 \mathrm{mg} / \mathrm{g}$. In this case, the predictive model obtained with ANN showed a better approach than RSM. This type of study is important, as NDES are contemplated to substitute the use of organic solvents.

Hydrodistillation consists of extracting volatile organic and non-organic compounds with distilled water. This technique involves three processes: hydrodiffusion, hydrolysis, and decomposition by heat [100]. The heat causes the breakdown of the cell structure, releasing aromatic compounds, and even the degradation of these compounds $[100,108]$. Therefore, this extraction technique has been used to obtain essential oils (terpenes or phytosterols) from plant waste. Recently, hydrodistillation has been used in combination with non-conventional technologies to increase the yield of volatile compounds. For example, Wu et al. [109] used conventional hydrodistillation and hydrodistillation combined with electrofluidic pretreatment to extract essential oils from grape and pomelo peel. The authors reported an increase of essential oils recovery yield (43\%) for grape peel and pomelo peel (93\%) using the combination of techniques. On the other hand, Bustamante et al. [110] indicated a slight increase (1.8\%) in the recovery yield of essential oils (mainly D-limonene, $\alpha$-pinene, sabinene, and R- $\beta$-myrcene) from orange (Navel navelate) peel using the microwave-assisted hydrodistillation compared to conventional hydrodistillation (1.7\%). Despite the slight increase reported, microwave-assisted hydrodistillation has been shown to reduce time, energy, and solvent consumption during the extraction of essential oils.

\subsection{Enzyme-Aided Extraction}

Conventional extraction strategies based on solvents' usage have been applied to exploit vegetable waste as a source of bioactive molecules. However, these traditional techniques involve several steps, including high temperatures and solvent recirculation, which could cause the bioactive molecules' chemical degradation [38,111]. In this regard, enzyme assisted extraction of biomolecules from plant origin represents an alternative to conventional solvent extraction techniques, since the biocatalytic processes function at mild temperatures and reduce the requirement of harmful solvents [112]. Additionally, the obtained bioproducts possess superior quality and are more suitable for human consumption $[28,113]$. 
Enzyme-assisted extraction has been used to extract various compounds from vegetable waste, such as carotenoids and flavonoids, among others [114-117]. However, in recent times, enzymatic technology is a trending biotechnological tool to obtain bioactive peptides from plant origin waste; in fact, bioactive peptides have received much attention because of their interesting functional and bioactive properties; and can be used as nutraceuticals for the development of functional foods $[38,118]$. Interestingly, enzyme-assisted extraction could be applied not only to produce bioactive peptides, but also to enhance their biological properties [119]. For instance, Esteve et al. [120] worked on the production of peptides from olive seed by utilizing five different commercial enzymes. These authors found that alcalase was the enzyme yielding the highest hydrolytic activity (degree of hydrolysis of $70.4 \%$ ). The highest antioxidant activities (DPPH, ABTS, and lipid peroxidation inhibition) were obtained with alcalase. Regarding antihypertensive property, peptides produced with thermolysin exhibited the highest ACE inhibition capacity $(29 \mu \mathrm{g} / \mathrm{mL})$. This result is related to thermolysin's specificity, an enzyme that catalyzes the hydrolysis of peptide bonds containing hydrophobic amino acids. It has been demonstrated that the most powerful antihypertensive peptides contain hydrophobic C-terminal amino acids [121].

To make the enzyme-assisted extraction process more efficient, it is important to work under optimized conditions. In this sense, several factors of enzymatic hydrolysis such as enzyme concentration, temperature, time, and $\mathrm{pH}$ of hydrolysis have been explored by using RSM [122,123], which is a collection of statistical and mathematical techniques useful for developing, improving, and optimizing processes in which several variables influence the response of interest [124]. In this regard, Karami, Peighambardoust, Hesari, and Akbari-Adergani [122] applied RSM to valorize wheat germ generated in the flour industry by the production of antioxidant peptides; in this study, temperature, time, and enzyme/substrate ratio were chosen as independent factors, whereas ferrous chelating activity, DPPH, ABTS radicals scavenging, and total antioxidant activity were evaluated responses. Time and enzyme/substrate ratio had significant effects on DPPH and ABTS radical scavenging $(P<0.05)$, whereas the quadratic terms of hydrolysis temperature exert a significant influence on antioxidant activity $(P<0.05)$. The suggested hydrolysis conditions for wheat germ peptides produced with alcalase were an enzyme/substrate ratio of $1.46 \%(w / w)$, a temperature of $52.28^{\circ} \mathrm{C}$, and a time of $233 \mathrm{~min}$. The model's validity was verified performing experiments under the mentioned optimal conditions, and experimental antioxidant values agreed with the model's predicted values within a $95 \%$ confidence interval.

Another interesting approach of enzyme-aided production of bioactive peptides from vegetable waste is the combination of enzyme technology with other green techniques, such as microwave, ultrasound, and supercritical fluid extraction, among others; this combination can boost the advantages of enzymatic extraction [125]. Görgüç et al. [126] obtained bioactive peptides from food waste sesame bran (Sesamum indicum L.) by using four different extraction methodologies: conventional alkaline extraction, enzymatic extraction (independent variables: enzyme concentration, $\mathrm{pH}$, temperature and time), ultrasound-assisted extraction (independent variables: ultrasound power and temperature), and ultrasound-assisted enzymatic extraction (independent variables: ultrasound power, enzyme concentration, temperature and time). RSM was applied to processes optimization, and the evaluated responses were protein yield (PY), total phenolic compounds (TPC), and antioxidant activity (DPPH and ABTS). By comparing the extraction procedures, combined ultrasound-assisted enzymatic extraction gave higher PY $(87.9 \%)$ compared to enzymatic extraction by alcalase $(79.3 \%)$, ultrasound-assisted extraction (59.8\%), and standard alkaline method (24.5\%). Additionally, enzymatic and ultrasound-assisted extraction methods increased total phenolic content and antioxidant activities compared to the traditional alkaline extraction methods. More studies related to the effect of enzymatic assisted extraction on yield and biological properties of peptides from vegetal waste are depicted in Table 2. 
Table 2. Applications of enzyme assisted extraction for the production of bioactive peptides from vegetable waste.

\begin{tabular}{|c|c|c|c|}
\hline Source & $\begin{array}{l}\text { Remarks Enzyme Aided } \\
\text { Extraction Processes }\end{array}$ & Effects on Variable Responses & Reference \\
\hline $\begin{array}{l}\text { Plum (Prunus Domestica } \\
\text { L.) seed waste }\end{array}$ & $\begin{array}{l}\text { Protein extracts obtained by } \\
\text { using four different enzymes: } \\
\text { alcalase, thermolysin, } \\
\text { flavourzyme, and protease P. }\end{array}$ & $\begin{array}{l}\text { Alcalase was the enzyme yielding the } \\
\text { extracts with the highest ABTS radical } \\
\text { scavenging and lipid peroxidation } \\
\text { inhibition capacities. Highest ACE } \\
\text { inhibitory capacity was observed } \\
\text { when using Thermolysin and alcalase }\end{array}$ & [127] \\
\hline $\begin{array}{l}\text { Walnut (Juglans regia } \\
\text { L.) kernels }\end{array}$ & $\begin{array}{l}\text { Enzymatic hydrolysate of } \\
\text { walnut seed proteins was } \\
\text { prepared by incubation with } \\
\text { chymotrypsin, trypsin, and } \\
\text { microbial proteinase K. }\end{array}$ & $\begin{array}{l}\text { Walnut peptides have substantially } \\
\text { higher antioxidant activity than intact } \\
\text { proteins. Highest antioxidant and } \\
\text { anticancer activity were exhibited by } \\
\text { peptides produced with chymotrypsin }\end{array}$ & [128] \\
\hline $\begin{array}{l}\text { Cauliflower (Brassica } \\
\text { oleracea L. var. botrytis) } \\
\text { waste leaves and stem }\end{array}$ & $\begin{array}{l}\text { By-product protein pellet was } \\
\text { hydrolyzed by alcalase } \\
\text { and trypsin }\end{array}$ & $\begin{array}{l}\text { Compared to trypsin, the use of } \\
\text { alcalase improved the antioxidant } \\
\text { activity of hydrolysates while } \\
\text { maintaining the } \\
\text { ACE-inhibitor activity. }\end{array}$ & [129] \\
\hline $\begin{array}{l}\text { Partially defatted } \\
\text { Riceberry bran }\end{array}$ & $\begin{array}{l}\text { The effect of enzyme type } \\
\text { (alcalase, flavourzyme and } \\
\text { neutrase) and hydrolysis time } \\
\text { (2, } 4 \text { and } 6 \mathrm{~h} \text { ) on protein yield, } \\
\text { total phenolic content (TPC), } \\
\text { and antioxidant activities } \\
\text { (ABTS and FRAP) } \\
\text { was investigated. }\end{array}$ & $\begin{array}{l}\text { The enzyme type } \\
\text { significantly }(p<0.05) \text { affected the } \\
\text { properties of peptides, whereas the } \\
\text { hydrolysis time had no significant } \\
\text { effect }(p \geq 0.05) \text {. Flavourzyme was the } \\
\text { most effective to increase protein } \\
\text { yield, TPC, and antioxidant activities } \\
\text { compared to alcalase and neutrase. }\end{array}$ & [130] \\
\hline Limonia acidissima seed & $\begin{array}{l}\text { Three-level three-factor Box } \\
\text { Behnken Design was } \\
\text { employed to predict the } \\
\text { optimal hydrolysis conditions } \\
\text { of L. acidissima using } \\
\text { pepsin. Evaluated } \\
\text { independent variables were: } \\
\text { pH, enzyme substrate ratio, } \\
\text { and time. }\end{array}$ & $\begin{array}{l}\text { The three evaluated factors }(\mathrm{pH}, \\
\text { enzyme substrate ratio, and time) } \\
\text { exerted a significant effect }(p<0.05) \\
\text { on degree of hydrolysis }(\mathrm{DH}) . \\
\text { The optimal conditions for } \mathrm{L} \\
\text { acidissima seed proteins were } \mathrm{pH} 2, \\
\text { enzyme substrate ratio of } 2.5 \%(w / w), \\
\text { and hydrolysis time of } 42.41 \mathrm{~min} \text {. } \\
\text { Under these conditions, a DH of } \\
36.59 \% \text { was achieved. }\end{array}$ & [131] \\
\hline $\begin{array}{l}\text { Food waste sesame bran } \\
\text { (Sesamum indicum L.) }\end{array}$ & $\begin{array}{l}\text { Three different strategies of } \\
\text { extraction were applied to } \\
\text { obtain peptides from sesame } \\
\text { bran: conventional alkaline } \\
\text { extraction (as a control), } \\
\text { microwave-assisted extraction } \\
\text { (independent variables: time } \\
\text { and temperature), and } \\
\text { combined microwave-assisted } \\
\text { enzymatic extraction, using } \\
\text { alcalase (independent } \\
\text { variables: enzyme } \\
\text { concentration, pH, and time of } \\
\text { hidrolysys). RSM was used to } \\
\text { optimize the processes. }\end{array}$ & $\begin{array}{l}\text { All the independent variables had a } \\
\text { significant effect on all of the } \\
\text { responses at a level of } p<0.001 \text {. } \\
\text { The highest protein yield was } \\
\text { obtained by combined } \\
\text { microwave-assisted enzymatic } \\
\text { extraction }(91.7 \%) \text {. } \\
\text { Total phenolic compound results were } \\
\text { in accordance with protein yields and } \\
\text { resulted as 3.45, } 4.20 \text {, and } 8.04 \mathrm{mg} \\
\text { GAE/g for alkaline, } \\
\text { microwave-assisted, and combined } \\
\text { extraction, respectively. } \\
\text { Microwave-assisted enzymatic } \\
\text { extraction was proven to be more } \\
\text { efficient than other techniques on the } \\
\text { extraction of protein and } \\
\text { bioactive compounds. }\end{array}$ & [9] \\
\hline
\end{tabular}

\subsection{Ultrasonic and Microwave Assisted Extraction}

Ultrasound-assisted extraction (UAE) is a useful extraction technique due to cavitational effects based on bubble dynamics, which are classified into sonochemical effects (SE) and mechanical effects (ME). At low frequency, ME dominates versus SE; this condition is normally recommended for the extraction of bioactive compounds from plants [132] as higher ultrasound power produces free 
hydroxyl radicals, which degrade phenolic compounds by SE mechanism, especially those with high water content $[133,134]$. According to Wang, et al. [135], at a high irradiation distance (50 mm), the ME is increased, reducing the generation of hydroxyl radicals and lowering the bioactive compounds' degradation. The UAE's parameters conditions, such as temperature, power, and time, influence the yield and antioxidant, anticancer, and antimicrobial properties of phenolic extracts [133]. Thus, all of these physical and chemical parameters must be taken into account to extract active molecules from plants, starting from the ultrasound source and extraction media, which could be direct or indirect (bath). The first one is the most effective; corrosion could be a problem [133].

Frequency is one of the most important parameters for bioactive compounds extraction. Low frequencies (20-40 kHz) have been observed to generate large cavitation bubbles, increasing shear and the number of microwaves and ensuring solvent penetration for higher extraction rate. Dual or multiple frequencies also increased the extraction yield [133]. Temperature is another important parameter in the UAE. Increasing temperature favors material porosity, solvation and mass transfer, reduced surface tension, and viscosity. For most bioactive compounds from plants, temperatures below $50{ }^{\circ} \mathrm{C}$ are recommended, especially for phenolic compounds; beyond this value, degradation can be produced by hydrolysis or oxidation; however, some compounds tolerate $60{ }^{\circ} \mathrm{C}$. Ultrasound power also has an influence in combination with frequency. A wide range of power has been applied for bioactive compounds, ranging from 25 to $150 \mathrm{~W}$ in most studies [133]. The selection of a solvent for UAE is critical and depends on polarity, melting point, boiling point, affinity, density, and gravity of the bioactive compound to be extracted. The toxic effect of the residual solvent in the final product and the possibility of reacting with the bioactive molecules must also be considered, and some solvents are difficult to remove during purification. Most of the solvents used in UAE are composed of a mixture of aqueous and organic phases in different ratios. Thus, organic solvents such as ethanol, methanol, acetone, and isopropanol have been used, and a common vegetal material:solvent ratio might vary between 1:3 and 1:5 [133]. All of these UAE parameters have been considered for the extraction of bioactive compounds in the following studies.

Asparagus phenolics extraction by ultrasound-assisted was increased $(3.95 \mathrm{mg} / \mathrm{g})$ at the selected intensities $12-120 \mathrm{~W}$ and temperatures of $25-35^{\circ} \mathrm{C}$ using the D101 resins [132]. A combination of hydrostatic pressure extraction and ultrasound-assisted extraction $(400 \mathrm{~W}, 30 \mathrm{kHz}$, working amplitude of $95 \%$ in a continuous cycle mode) with ethanol $70 \%$ and $15 \mathrm{~min}$ obtaining $3643.9 \mathrm{mg} / 100 \mathrm{~g}$ of phenolic compounds from tomato peel waste [136]. For orange peel phenolic compounds the next conditions were applied: water:ethanol $(80: 20, v / v)$, temperatures from $25-90{ }^{\circ} \mathrm{C}$, and time $=15$ min; with a ratio of dry vegetal material: solvent $=0.3: 50 \mathrm{~g} / \mathrm{mL}$, the recovered phenolic compounds were trans ferulic acid $(0.29-1.38 \mathrm{mg} / \mathrm{g})$, rutin $(3.3-4.7 \mathrm{mg} / \mathrm{g})$, and hesperidin $(280-673 \mathrm{mg} / \mathrm{g})$ [137]. In the case of grape pomace polyphenols, a ratio of dry vegetal material:solvent $=1: 70 \mathrm{~g} / \mathrm{mL}$ in water: ethanol $(1: 1, v / v)$, frequency $=25 \mathrm{kHz}$, temperature $=20{ }^{\circ} \mathrm{C}$, power $=300 \mathrm{~W}$, and time $=1 \mathrm{~h}$. Under these conditions the following phenolic compounds were recovered: TPC $(438,984$ ppm GAE $\mathrm{dw})$, total flavan-3-ol (43,469 ppm CE), total anthocyanin (34,188 ppm Mv-3-glc eq), and total flavonol (4484 ppm QE) [138]. SRM has been applied to optimize bioactive compounds from vegetal material applying UAE. Chmelová et al. [139] increased phenolic compounds extraction from Spruce bark (Picea abies), varying the independent variables temperature, liquid to solid ratio, time, and methanol content, and the optimal conditions were $63{ }^{\circ} \mathrm{C}$, methanol content of $53 \%(v / v)$, and $38 \mathrm{~mL}$ of extraction solvent per gram of dry material. The UAE has been applied with other extractive methods such as adsorption/desorption with amberlite resins to extract phenolic compounds from apple skin [140]. As can be seen, UAE conditions must be adapted to each vegetal source and bioactive compound to be extracted considering all the factors discussed above.

Microwave-assisted extraction is a green extraction technique that has been explored to obtain antioxidant compounds, such as phenolics, from vegetable waste. For instance, Carbone et al. [141] evaluated the effects of temperature, extraction time, solvent composition (ethanol:water), and solid-solvent ratio on the microwave-assisted extraction of phenolic compounds from kiwi pomace. 
Furthermore, these authors compared the efficacy of the predictive models produced with RSM and ANN to obtain the optimal conditions of extraction. At the optimal conditions of microwave-assisted extraction (T: $75^{\circ} \mathrm{C}$; time: $15 \mathrm{~min}$, solvent composition: 50\% ethanol:water, and solid-solvent ratio: 1:15), it was possible to obtain a total phenolic content of $4.79 \pm 0.13 \mathrm{mg}$ GAE/g from the kiwi pomace. Furthermore, the antioxidant capacity, measured with the DPPH and ABTS assays, of the optimized extracts were $\mathrm{EC}_{50}=5.49 \pm 0.02 \mathrm{mg}$ and $560 \pm 1 \mu \mathrm{g}$, respectively. Authors concluded that both models were efficient to predict the optimal conditions of microwave-assisted extraction; nevertheless, ANN showed higher predictive capability and accuracy than RSM. Nevertheless, the RSM model allowed to determine the significance of each variable under study.

\subsection{Pressurized Liquid Extraction}

Pressurized liquid extraction (PLE) is a solid-liquid extraction method that utilizes pressurized liquids, as extractant solvent, at elevated temperatures and pressures, below their critical point. The PLE applies high pressures to the solvent, so it remains in a liquid state beyond its normal boiling point [142]. The use of high temperatures at high pressures increases the analyte's solubility by uprising both solubility and mass transfer rate; furthermore, this reduces the viscosity and surface tension of solvents [103]. Therefore, the PLE accomplishes faster and efficient extractions, with the advantage that requires smaller volumes of solvents than traditional methods, such as maceration and Soxhlet extraction [143].

PLE has been effectively applied to extract bioactive compounds from different vegetable waste sources. For instance, Xu et al. [144] used RSM to optimize PLE of spent coffee grounds (Coffea arabica L.), focusing on the total recovery of phenolic compounds and antioxidant activity by the ABTS method, using water as a solvent. The parameters under study were temperature $\left(160-180{ }^{\circ} \mathrm{C}\right)$, time of extraction (35-55 $\mathrm{min})$, and solid-to-liquid ratio (14.1-26.3 g/L). The pressure was kept constant at 5.0 MPa. Results showed that phenolic compounds recovery was enhanced with the increase of temperature. This effect might be because high temperatures rise the diffusion coefficient of solvent and reduce the solvent viscosity, which increases the diffusion rate of analytes and the solubility of solutes [145]. Authors found that the conditions of PLE that optimized the recovery of phenolic compounds (88.34 mg GAE/g) and antioxidant activity (88.65 mmol TE/100 g) of the extract from spent coffee grounds were a temperature of $179{ }^{\circ} \mathrm{C}$, a time of extraction of $36 \mathrm{~min}$, and a ratio of $14.1 \mathrm{~g} / \mathrm{L}$. The main phenolic acids present in the extract were 3-O-caffeoylquinic acid, 4-O-caffeoylquinic acid, and 5-O-caffeoylquinic acid, at which the authors adjudicate the antioxidant properties of the extract obtained.

Furthermore, Yan et al. [146] used the RSM for optimization of PLE conditions, using water as a solvent, for the recovery of phenolic compounds from pomegranate (Punica granatum L.) peels. The variables under study were temperature $\left(110-150{ }^{\circ} \mathrm{C}\right)$, time of extraction $(10-30 \mathrm{~min})$, and solvent-solid ratio $(40-60 \mathrm{~mL} / \mathrm{g}, v / w)$. The pressure was kept constant at 3.0 MPa. The yield of recovery of TPC was increased as the temperature augmented. At high pressure and temperature, the water dielectric constant is lower to an extent similar to those of some organic solvents, such as methanol and ethanol [147]. Results also showed that TPC's yield was increased when the time of extraction raised from 5 to $20 \mathrm{~min}$; nevertheless, when the extraction time was extended up to 20 to $80 \mathrm{~min}$, the yield of bioactive compounds recovered was reduced. This information indicates that the extension of extraction time will not result in higher extraction yields; furthermore, prolonged extraction time might lead to some compounds' degradation [147]. The authors reported that optimum conditions for TPC content (323.10 mg GAE/g) and antioxidant activity (476.81 mg TE/g) from pomegranate peels were a temperature of $126.1^{\circ} \mathrm{C}$, time of extraction of $18.5 \mathrm{~min}$, and a solvent-solid ratio of $54.8 \mathrm{~mL} / \mathrm{g}$. According to Yan, Cao, and Zheng [146], PLE is a very efficient and environmentally friendly technique that can be used over conventional extraction methods to recover antioxidant phenolic compounds from pomegranate peels. 
Saravana et al. [148] evaluated the effect of temperature $\left(180-240{ }^{\circ} \mathrm{C}\right)$, pressure $(15-45 \mathrm{bar})$, solid-solvent ratio (0.04-0.09 g/mL), extraction time (5-15 min), and agitation speed (100-200 rpm) on the PLE (water) of total saponins, TPC, and antioxidant activity from extracts recovered from ginseng (Panax ginseng Meyer) waste. The optimization of the process conditions was performed using RSM to improve the recovery of the bioactive compounds previously mentioned. The authors found that the solid-solvent ratio is a key factor influencing the yields of bioactive compounds and antioxidant activity. Recovery of saponins, phenolic compounds, and yield of antioxidant activity were enhanced as the solid-solvent ratio was up to $0.05 \mathrm{~g} / \mathrm{mL}$. This might be because a high volume of extractant causes extreme swelling of the matrix, which disrupts the plant cell walls and facilitates the mass transfer [149]; nevertheless, when the solid-solvent ratio augmented above $0.07 \mathrm{~g} / \mathrm{mL}$, the solution turned out to be saturated with the solute, this negatively affected the release of the bioactive compounds to the extractant, which reduced the extraction yields. The agitation speed also significantly affected the yield of saponin and phenolic compounds content, as well as the antioxidant activity of extracts obtained by PLE from ginseng waste. When agitation speed was greater than $180 \mathrm{rpm}$, the recovery of bioactive compounds was increased. It has been established that the augmentation of agitation speeds causes high mass transfer coefficients and improves the extraction process, enhancing the extraction yields [150]. The effect of temperature and pressure in PLE of bioactive compounds was similar, as discussed previously in this manuscript. Therefore, the optimum conditions for total saponins (7.12 g Ginsenoside Re equivalent/100 g) and TPC (49.11 mg GAE/100 g) recovery, and antioxidant activity $(5.31 \mathrm{TE} / 100 \mathrm{~g})$, were a temperature of $207^{\circ} \mathrm{C}$, a pressure of $43.45 \mathrm{bar}$, a solid-solvent ratio of $0.04 \mathrm{~g} / \mathrm{mL}$, extraction time of $15 \mathrm{~min}$, and an agitation speed of $199 \mathrm{rpm}$. Furthermore, it was reported that homogentisic and gentisic acids were the main phenolic compounds present in the ginseng waste extract obtained by PLE.

A more recent study by Munir et al. [151] explored the recovery of bioactive compounds from onion (Allium cepa L.) skin waste using PLE, with water as a solvent. The authors used a face-centered central composite design of RSM to evaluate the effect of temperature $\left(170-230{ }^{\circ} \mathrm{C}\right), \mathrm{pH}(2-10)$, and particle size (100-200 mm (S1), 200-500 mm (S2), and 500-850 mm (S3)) on the phenolic and flavonoid content, as well as antioxidant activity (DPPH) of extracts from onion skin waste. Conditions of pressure, agitation speed, and extraction time were kept constant at $30 \mathrm{bar}, 400 \mathrm{rpm}$, and $30 \mathrm{~min}$, respectively. As expected, results showed that at higher particle size, the recovery of bioactive compounds and antioxidant activity were reduced. This might be because, at a higher particle size, the contact surface of the matrix and the extractant is decreased, which lowers the mass transfer and the extraction efficiency [152]. The $\mathrm{pH}$ also affected the bioactive compounds and antioxidant yields. The antioxidant compounds yield was reduced as the $\mathrm{pH}$ was increased. This reduction in the phenolic and flavonoid content with higher $\mathrm{pH}$ might be because polyphenols are acidic and begin to degrade under alkaline conditions [153]. The authors reported that the optimum conditions for PLE of phenolic compounds ( $\sim 200 \mathrm{mg} \mathrm{GAE} / \mathrm{g}$ ) and flavonoid ( $\sim 90 \mathrm{mg}$ quercetin equivalent/g) content and antioxidant activity ( $\sim 400 \mathrm{mmol} \mathrm{TE} / \mathrm{g}$ ) of extracts from onion skin waste were a temperature of $170-230{ }^{\circ} \mathrm{C}, \mathrm{pH}$ of 6 , and particle size of 200-500 mm. Furthermore, quercetin and kaempferol were the main flavonoids identified in the extracts obtained from onion skin waste by PLE. The authors mentioned that using water as a solvent in the PLE is an efficient method to recover bioactive compounds with antioxidant activity from vegetable waste, such as onion skin.

\subsection{Supercritical Fluid Extraction}

Supercritical fluids are frequently used in industry as an alternate option to solvent extraction. Due to their exclusion of toxic solvents from processes, supercritical fluids are recognized as "environmentally friendly". One of the main advantages of using supercritical fluid extraction (SFE) for the recovery of bioactive compounds is that a supercritical fluid possesses a lower viscosity and a higher diffusion coefficient than a liquid solvent, which leads to a more efficient and easier penetration of the solvent to the sample matrix, enhancing the mass transfer. Furthermore, SFE is 
usually performed at room temperature [103]. Another advantage of supercritical fluids is that separation of the compound of interest from the liquid is easy and usually does not require additional steps. Carbon dioxide $\left(\mathrm{CO}_{2}\right)$ is the solvent most frequently used in supercritical fluid extraction, since it is safe, available, and cheap; furthermore, $\mathrm{CO}_{2}$ present low critical temperature $\left(31.1^{\circ} \mathrm{C}\right)$ and pressure (73.7 bar), which reduces the degradation of thermolabile compounds and exerts selectivity for the compounds of interest [154]. Generally, most of the compounds extracted using SFE are non-polar or mid-polar compounds, such as terpenes (essential oils and carotenoids). The reason is that their low polarity limits the use of supercritical $\mathrm{CO}_{2}$; nevertheless, co-solvents, such as ethanol, have been used to extract more polar compounds [155].

SFE is a technology that has been vastly used to obtain bioactive compounds from vegetable waste [156]. Nevertheless, optimum conditions will vary depending on the extraction solvent, co-solvent, temperature, pressure, time, and solvent flow rate. These parameters are very important to consider in the optimization of the extraction process; changes in these variables might alter the selectivity of the process and the yield of the final product [157].

In this regard, Ndayishimiye and Chun [158] studied the optimum supercritical $\mathrm{CO}_{2}$ extraction conditions to maximize carotenoid content in the citrus Yuzu ichandrin waste (mixture of seeds and peels) oils. The authors evaluated the effect of temperature $\left(40-50^{\circ} \mathrm{C}\right)$, pressure $(20-30 \mathrm{MPa})$, and mixing ratio $(1.5-3.0 \mathrm{~g} / \mathrm{g})$ on the carotenoid content and antioxidant activity of extracted oils by applying the RSM. It was observed that when temperature and mixing ratio were kept constant, the carotenoid content augmented with the increasing of the pressure. This might be because at high pressures, the density of $\mathrm{CO}_{2}$ increases; therefore, carotenoids' solubility in the solvent rises. According to the authors, the optimum conditions for carotenoid recovery from Yuzu ichandrin waste were the pressure of $25.196 \mathrm{MPa}$, temperature of $44.88^{\circ} \mathrm{C}$, and a mixing ratio of 1.91 , which gave predicted values of $1.983 \mathrm{mg}$ of carotenoid/g of oil. Another study where the optimization of SFE of carotenoids was explored is the one by de Andrade Lima et al. [159]. In this study, the authors determined the optimal conditions for carotenoids extraction from carrot peels by SFE using $\mathrm{CO}_{2}$ and ethanol as co-solvent. The variables evaluated were temperature $\left(50,60\right.$, and $\left.70{ }^{\circ} \mathrm{C}\right)$, pressure $(150,250$, and 350 bar), and co-solvent (ethanol) percentage $(5,10$, and $15 \%, v / v)$. The response variables under study were the total mass yield and carotenoid recovery. The authors found that the optimal conditions for the highest mass yield $(5.31 \%)$ were temperature of $58.5^{\circ} \mathrm{C}$, pressure of $306 \mathrm{bar}$, and ethanol percentage of $14.3 \%$, while the optimal conditions for the maximum carotenoid recovery $(86.1 \%)$ were temperature of $59{ }^{\circ} \mathrm{C}$, a pressure of 349 bar, and co-solvent percentage of $15.5 \%$. The authors mentioned that this research's findings could be applied for other vegetable residues aiming to obtain carotenoids. Furthermore, Derrien et al. [160] evaluated the optimization of luteolin and chlorophyll extraction conditions from spinach (Spinacia oleracea) waste. The authors used a Box-Behnken design to optimize the extraction process using different conditions of pressure $(10,30$, and $50 \mathrm{MPa})$, temperature $\left(40,50\right.$, and $\left.60^{\circ} \mathrm{C}\right)$, time $(1,3$, and $5 \mathrm{~h})$, and co-solvent (ethanol) percentages $(0,5$, and $10 \%, v / v)$; the solvent flow rate was kept constant $(10 \mathrm{~g} / \mathrm{min})$. It was reported that the optimum extraction variables were temperature of $56^{\circ} \mathrm{C}$, time of $3.6 \mathrm{~h}$, pressure of $39 \mathrm{MPa}$, and $10 \%$ of co-solvent. These parameters resulted in a yield of $72 \%$ of luteolin and $50 \%$ of chlorophyll. The authors mentioned that supercritical fluid $\mathrm{CO}_{2}$ is a suitable technique for extracting these terpenes from spinach residues, which is a potential alternative to replace conventional solvent extraction. Additionally, Kitryte et al. [161] evaluated the separation of terpene-phenolic compounds from industrial hemp (Cannabis sativa) threshing residues by optimizing the extraction parameters of temperature $\left(35-70{ }^{\circ} \mathrm{C}\right)$, time (60-120 $\left.\mathrm{min}\right)$, and pressure (10-50 MPa). $\mathrm{CO}_{2}$ flow rate (2-3 SL/min) was kept constant, and a central composite design and RSM were used for the optimization of parameters. It was observed that at a pressure of up to $30 \mathrm{MPa}$, the increase of temperature positively affected terpene-phenolic compounds' recovery. The authors mentioned that this effect might be because the increase of the solute's vapor pressure could compensate the reduced solvating power of $\mathrm{CO}_{2}$. The authors report that the optimum conditions to obtain terpene-phenolic compounds from hemp threshing residues are a pressure of $46.5^{\circ} \mathrm{C}$, a temperature of $70^{\circ} \mathrm{C}$, and a time 
of extraction of $120 \mathrm{~min}$, which resulted in a yield of $24.72 \mathrm{mg} / \mathrm{g}$ of extract. The use of supercritical $\mathrm{CO}_{2}$ under the optimum conditions reported by Kitrytė, Bagdonaitè, and Rimantas Venskutonis [161] might be an efficient way to recover the main bioactive components from industrial hemp residues.

A more recent study where vegetable wastes were used to obtain bioactive compounds using SFE and RSM is the one by Piechowiak et al. [162]. In their study, the authors determined the optimal process conditions using RSM to recover antioxidant compounds from yellow onion (A. cepa L.) skin. The extraction parameters evaluated were temperature $\left(12.5-59.5{ }^{\circ} \mathrm{C}\right)$, time $(5.7-224 \mathrm{~min})$, and the ratio of onion skin mass to methanol volume $(0.026-0.062 \mathrm{~g} / \mathrm{mL})$. The response variables were yield of extraction, phenolic compounds content, and antioxidant activity of the dried extract. As expected, the results showed that the total yield of recovery of antioxidant components from onion skin using methanol as a solvent was dependent on the process conditions. The parameters that optimized the extraction process were a temperature of $44^{\circ} \mathrm{C}$, a time of $145 \mathrm{~min}$, and a ratio of $0.033 \mathrm{~g} / \mathrm{mL}$. These conditions resulted in a total yield of $8.23 \pm 0.52 \mathrm{~g}$ dried extract $/ 100 \mathrm{~g}$ of onion skin, phenolic compounds recovery of $3.24 \pm 0.25 \mathrm{~g}$ quercetin/100 $\mathrm{g}$ of onion skin, and antioxidant activity of $401.52 \pm 23.02 \mathrm{mg}$ quercetin/g of extract. Furthermore, the content of quercetin, quercetin-3-glucoside, isorhamnetin, and kaempferol was $315.6 \mathrm{mg} / \mathrm{g}$ extract, $40.3 \mathrm{mg} / \mathrm{g}, 14.8 \mathrm{mg} / \mathrm{g}$, and $10.9 \mathrm{mg} / \mathrm{g}$, respectively.

This kind of method shows that by regulating the extraction conditions, it is possible to optimize the recovery of bioactive compounds from vegetable waste systematically.

Conventional and non-conventional extraction technologies can present several advantages and disadvantages, which are summarized in Table 3.

Table 3. Comparisson of extraction techniques for obtaining antioxidant compounds.

\begin{tabular}{|c|c|c|c|c|}
\hline Technique & $\begin{array}{c}\text { Main } \\
\text { Parameters/Factors }\end{array}$ & Advantages & Disadvantages & Reference \\
\hline Maceration & $\begin{array}{l}\text { Solvents, } \\
\text { solid-to-solvent ratio, } \\
\text { agitation, temperature, } \\
\text { time of extraction }\end{array}$ & $\begin{array}{l}\text { Simple method, it does not } \\
\text { require expensive equipment, } \\
\text { the use of mild temperature } \\
\text { conditions allows to extract } \\
\text { thermolabile compounds }\end{array}$ & $\begin{array}{l}\text { Use of great volumes of } \\
\text { organic solvents, prolonged } \\
\text { time of extraction, it requires } \\
\text { an adittional step of separation } \\
\text { (evaporation/concentration) }\end{array}$ & [163] \\
\hline Hydrodystillation & $\begin{array}{c}\text { Particle size, } \\
\text { time of extraction, } \\
\text { solid-to-solvent ratio }\end{array}$ & $\begin{array}{l}\text { It does not require organic } \\
\text { solvents (water can be used) }\end{array}$ & $\begin{array}{l}\text { Thermolabile compounds } \\
\text { can be degraded, prolonged } \\
\text { time of extraction }\end{array}$ & [100] \\
\hline $\begin{array}{l}\text { Ultrasonic-assisted } \\
\text { extraction }\end{array}$ & $\begin{array}{l}\text { Frequency, extraction } \\
\text { time, temperature }\end{array}$ & $\begin{array}{l}\text { Higher recovery of } \\
\text { targeted compounds, }\end{array}$ & $\begin{array}{l}\text { Requires specific equipment, } \\
\text { might degrade unstable } \\
\text { compounds (carotenoids) }\end{array}$ & [164] \\
\hline $\begin{array}{l}\text { Microwave-assisted } \\
\text { extraction }\end{array}$ & $\begin{array}{l}\text { Frequency, time of } \\
\text { microwave, moisture } \\
\text { content, particle size, } \\
\text { solid-to-liquid } \\
\text { ratio, temperature }\end{array}$ & $\begin{array}{l}\text { Reduces extraction time and } \\
\text { solvent consumption, shows a } \\
\text { higher performance in the } \\
\text { recovery of } \\
\text { bioactive compounds }\end{array}$ & $\begin{array}{l}\text { Requires specific equipment, } \\
\text { increases in temperature can } \\
\text { cause the generation of } \\
\text { undesirable compounds } \\
\text { (hydroxymethylfurfural) }\end{array}$ & [165] \\
\hline $\begin{array}{l}\text { Pressurized } \\
\text { liquids }\end{array}$ & Temperature, pressure & $\begin{array}{l}\text { Faster and efficient extractions, } \\
\text { requires smaller volumes of } \\
\text { solvents than } \\
\text { traditional methods }\end{array}$ & $\begin{array}{l}\text { Might not suitable for } \\
\text { thermolabile compounds } \\
\text { (the high temperatures can } \\
\text { degrade the chemical } \\
\text { structure and functional } \\
\text { activity of targeted } \\
\text { compounds) }\end{array}$ & {$[142,166]$} \\
\hline $\begin{array}{l}\text { Supercritical } \\
\text { fluids }\end{array}$ & $\begin{array}{c}\text { Temperature, pressure, } \\
\text { co-solvent, time, } \\
\text { particle size }\end{array}$ & $\begin{array}{l}\text { More efficient extraction, } \\
\text { doesn't require additional } \\
\text { steps of separation, more } \\
\text { specificity towards the } \\
\text { targeted compounds, } \\
\text { maintains the chemical } \\
\text { structure and functional } \\
\text { activity of } \\
\text { targeted compounds }\end{array}$ & $\begin{array}{l}\text { Requires expensive } \\
\text { equipment, although it is } \\
\text { already used in industrial } \\
\text { processes, such as coffee } \\
\text { decaffeination }\end{array}$ & [155] \\
\hline
\end{tabular}




\section{Potential Health Benefits of Recovered Bioactive Compounds of Plant Waste}

\subsection{Antioxidant Properties}

Physiological oxidants are generated during regular cellular metabolism processes, such as respiration. Examples os these oxidants, also known as free radicals or reactive species, are singlet oxygen, hydroxyl radical (OH·-), superoxide anion $\left(\mathrm{O}_{2} \cdot-\right)$, hydrogen peroxide $\left(\mathrm{H}_{2} \mathrm{O}_{2}\right)$, and lipid peroxides, among others [167]. Oxidative stress is caused by elevated levels of reactive oxygen species (ROS) or the decline of the antioxidant defenses in the organism, causing a cellular oxidative environment that triggers the damage of indispensable biomolecules like proteins, lipids, and DNA [168]. For example, during oxidative stress, the oxidation of lipids may occcur, with the formation of malondyaldehyde (MDA) and 4-hydroxy-2-nonenal (4-HNE), this process is known as lipid peroxidation [169]. Oxidative stress has been associated to the incidence and progression of several diseases, such as diabetes, cancer, cardiovascular or neurodegenative disorders, atherosclerosis, etc. [167]. Therefore, the study of potential antioxidant molecules to conteract the damaging effect of reactive species is very important.

An antioxidant is a molecule or substance that may retard or inhibit the oxidation or oxidative cell damage caused by the oxidants. The antioxidants can exert their activity by directly reacting with free radicals, that is, donating one electron [170]. Antioxidants are able to stabilize themselves by the resonance of their chemical structure and therefore break the oxidation chain. Molecules can also act as antioxidants by interacting with transcription factors [171]. For instance, NF-kB and Nrf2 are transcription factors involved in the gene expression of antioxidant enzymes, such as superoxide dismutase (SOD), catalse (CAT), and glutathione peroxidase (GPx), which are the first line defense in the cells against reactive species [172]. Vegetable wastes have been explored as a potential source to obtain molecules or compounds with antioxidant activity. For instance, phenolic compounds from avocado seed and peel have been demonstrated to possess antioxidant properties by showing high radical scavenging activity against ROS, such as peroxyl superoxide (ROO) (2.2-10.6 $\mu \mathrm{mol}$ TE/g) and hypochlorous acid $(\mathrm{HOCl})\left(\mathrm{EC}_{50}=5.2-8.6 \mu \mathrm{g} / \mathrm{mL}\right)$ [173]. Furthermore, phenolic compounds from mango peels, such as gallic acid and quercetin, increase the activity of CAT and reduce the MDA levels, as a biomarker of lipid peroxidation, in an in-vivo model of zebrafish (Danio rerio) [174]. Lycopene (4.9\%), a tetraterpene, from tomato peel, has been demonstrated to exert antioxidant activity via reducing the levels of ROS and diminishing the DNA fragmentation induced by $\mathrm{H}_{2} \mathrm{O}_{2}$ in $\mathrm{L} 6$ cells (myoblasts) [175]. Aditionally, lutein, a carotenoid present in residues of lettuce or cabbage [176], has shown efficient scavenging activity against ROO- in human erythrocytes. Moreover, lutein was able to reduce lipid peroxidation in the erythrocytes [177]. These studies show the potential protective effect of carotenoids against oxidative damage.

Phytosterols are a group of bioactive compounds present in the seeds and kernels of fruits and cereals that have demonstrated antioxidant activity, for instance, seeds from Capsicum annuum contain sterols, such as campesterol, stigmasterol, and $\beta$-sitosterol. It has been reported that extracts from pepper (C. annuum) seeds showed a significant antioxidant effect by reducing superoxide radical in $45-47 \%$ at concentrations below $0.05 \mathrm{mg} / \mathrm{mL}$ [178]. Aditionally, lipid extracts from avocado seeds, rich in sterol compounds, namely $\beta$-sitosterol and campasterol, exerted inhibitory activity against synthetic radicals (ABTS and DPPH) at $200 \mu \mathrm{g} / \mathrm{mL}$ [179]. Furthermore, $\beta$-sitosterol reduced $\mathrm{H}_{2} \mathrm{O}_{2}$ and $\mathrm{ROS}$ levels in RAW 264.7 macrophage cells stimulated with phorbolmyristate acetate [180]. These results propose the important antioxidant activity of phytosterols from vegetable waste.

Bioactive peptides from vegetable waste are important, since their role in the prevention of oxidative stress has been recognized. For instance, date seed protein hydrolysates, with 11-14\% degree of hydrolysis, showed significant antioxidant activity by scavenging the hydroxyl radical from 12.3 to $43.8 \%$ [181]. Furthermore, cherry seed protein hydrolysates obtained with thermolysin $(55 \pm 5 \%$ degree of hydrolysis) significantly inhibited the hydroxyl radical and lipid peroxidation in $\sim 30 \%$ and $\sim 80 \%$, respectively, in in-vitro assays [182]. 
These studies reveal the potential of vegetable wastes as imporant and sustainable sources for obtaining antioxidant molecules that might exert positive health benefits. This topic will be discussed below.

\subsection{Anti-Obesity and Anti-Diabetic}

Obesity is a chronic problem characterized by excess body fat, high prevalence, and increasing demand for care. It is considered a true epidemic of the 21st century, being increased worldwide. The etiology of obesity includes genetic and environmental factors that interact in a complex way, resulting in an excessive increase in adipose body mass due to the accumulation of fat in the tissue and the decrease in energy expenditure. Obesity implies a health risk, since it is associated with a whole set of metabolic abnormalities known as metabolic syndrome. These include type II diabetes mellitus, dyslipidemias, cardiovascular disease, high blood pressure, and certain cancer types. One of the most serious complications of obesity is insulin resistance, since it is directly related to the appearance of type II diabetes [183].

The main treatments for diabetic patients are lifestyle changes and administration of pharmacological drugs like metformin or acarbose, sulphonylureas, dipeptidyl peptidase four inhibitors, glucagon-like peptide 1, and if necessary, insulin injections [184]. These treatments are often costly and hard to acquire for people from low- and middle-income countries. Thus, diabetic patients often incorporate medicinal plants or their infusions as a main source of treatment or concomitance to the drugs mentioned before (whether the physician is aware or not). This has led to an increased interest of scientists in the evaluation and analysis of natural compounds from plants as potential antidiabetic agents. In this sense, phenolic compounds have been of great interest due to their potential capacity as inhibitors of the carbohydrate metabolic enzymes $\alpha$-glucosidase and $\alpha$-amylase, targets of the drug acarbose, to prevent increased plasmatic glucose levels after food intake [185]. Phenolic compounds can be found almost ubiquitously in all plants; thus, they are present in fruit and vegetables. Studies have also shown that phenolic compounds can also be found in high concentrations in fruit and vegetable waste, which is now being considered a new rich source of these phytochemicals. These wastes can be used to elaborate added-value products in the food industry and the biopharmaceutical industry [186,187].

Most of the phenolic compounds identified in vegetable waste as potential antidiabetic agents are phenolic acids and flavonoids and their derivatives (Table 4). These compounds are distributed in most waste of the plant-food industry. However, the peel and pomace are the main wastes that have been studied for valorization in antidiabetic and anti-obesity studies. In a recent study by Alongi, Melchior, and Anese [11], the authors enriched short dough biscuits with apple pomace to reduce the bakery product's glycemic index. Apple pomace is a source of phenolic compounds and a rich source of dietary fiber. In this sense, the authors report that replacement of wheat flour with 10 and $20 \%$ of apple pomace flour enhanced the dietary fiber content of the biscuits, with $40 \%$ of dietary fiber content. Furthermore, the biscuits with apple pomace showed a reduced glycemic index, which lowered from a glycemic index of 70 in non-treated biscuits to a 60-65 glycemic index, achieving a classification of an intermediate glycemic index food. This work shows that apple pomace is a suitable option to incorporate on functional foods with a lower glycemic index aimed for diabetic patients. 
Table 4. Phytochemicals found in vegetable waste with antidiabetic and anti-obesity potential.

\begin{tabular}{|c|c|c|c|c|c|}
\hline Waste & Scientific Name & Plant Part & Method of Identification & Compounds & Reference \\
\hline $\begin{array}{l}\text { Pomegranate }(15 \\
\text { different varieties) }\end{array}$ & Punica granatum $\mathrm{L}$. & Peel decoctions & $\begin{array}{l}\text { HPLC-DAD and } \\
\text { HPLC-MS }\end{array}$ & $\begin{array}{l}\text { Punicalagin, cyanidin-3,5-O-diglucoside, } \\
\text { delphinidin-3-O-glucoside, cyanidin-3-O-glucoside, } \\
\text { pelargonidin-3-O-glucoside }\end{array}$ & [188] \\
\hline Pomegranate & Punica granatum $\mathrm{L}$. & Peel & HPLC-DAD-ESI-MS & $\begin{array}{l}\text { Protocatechuic acid, cis-p-coumaric acid, trans-p-coumaric acid, } \\
\text { vanillic acid, gallic acid, hydroxygallic acid, hydroxycaffeic acid, } \\
\text { vanillic acid hexoside, caffeic acid hexoside, ferulic acid hexoside, } \\
\text { 5-O-caffeoylquinic acid }\end{array}$ & [189] \\
\hline Pomegranate & Punica granatum $\mathrm{L}$. & Peel & $\begin{array}{l}\text { HPLC-DAD and } \\
\text { LC-MS/MS }\end{array}$ & $\begin{array}{l}\text { Punicalin, punicalagin, pedunculagin, castalagin derivate, ellagic } \\
\text { acid hexoside, ellagic acid pentoside, ellagic acid deoxyhexoside, } \\
\text { ellagic acid, gallic acid }\end{array}$ & [20] \\
\hline Pomegranate & Punica granatum L. & Peel & HPLC & $\begin{array}{c}\text { Punicalagin, pyrogallol, ellagic acid, gallic acid, protocatechuic } \\
\text { acid, chlorogenic acid, p-hydroxybenzoic acid, cinnamic acid, } \\
\text { hesperidin, quercitrin }\end{array}$ & [190] \\
\hline Passion fruit & Passiflora edulis & Peel & HPLC & Caffeic acid and isoorientin & [191] \\
\hline Naranjilla & Solanum quitoense & Peel & \multirow{6}{*}{ UHPLC-HRMS } & $\begin{array}{c}\text { Chlorogenic acid, p-coumaric acid, gallic acid, rutin } \\
\text { hydrate, taxifolin }\end{array}$ & \multirow{6}{*}{ [192] } \\
\hline Cape gooseberry & Physalis peruviana & Peel & & Chlorogenic acid, gallic acid, polydatin, rutin hydrate, & \\
\hline Tamarillo & Cyphomandra betaceae & Peel & & $\begin{array}{l}\text { Chlorogenic acid, p-coumaric acid, ferulic acid, rutin hydrate, } \\
\text { sinapic acid, syringaldehyde, taxifolin }\end{array}$ & \\
\hline Poro poro & Passiflora pinnatistipula & Peel & & $\begin{array}{l}\text { Trans-cinnamic acid, p-coumaric acid, (-)-epicatechin, ferulic acid, } \\
\text { gallic acid, polydatin, rutin hydrate, sinapic acid, taxifolin }\end{array}$ & \\
\hline Curuba & Passiflora tripartita & Peel & & $\begin{array}{l}\text { (+)-catechin, p-coumaric acid, ferulic acid, polydatin, sinapic acid, } \\
\text { vanillic acid }\end{array}$ & \\
\hline Sweet granadilla & Passiflora ligularis & Peel & & $\begin{array}{l}(+) \text {-catechin, chlorogenic acid, p-coumaric acid, ferulic acid, gallic } \\
\text { acid, homogentisic acid, polydatin, sinapic acid, vanillic acid }\end{array}$ & \\
\hline Araticum & Annona crassiflora Mart. & Peel & HPLC-ESI-MS/MS & $\begin{array}{l}\text { Catechin, epicatechin, rutin, quercetin, protocatechuic acid, gentisic } \\
\text { acid, chlorogenic acid, p-coumaric acid, ferulic acid }\end{array}$ & [193] \\
\hline Longan & Dimocarpus longan & Peel & HPLC-DAD & $\begin{array}{l}\text { Ellagic acid, corilagin, gallic acid, o-coumaric acid, ferulic acid, } \\
\text { chlorogenic acid, quercetin, kaempferol }\end{array}$ & [194] \\
\hline Red grape & Vitis vinifera $\mathrm{cv}$. Sangiovese & Peel & HPLC-DAD & $\begin{array}{c}\text { Gallic acid, (+)-catechin, caffeic acid, (-)-epicatechin, rutin, } \\
\text { trans-resveratrol, quercetin }\end{array}$ & [195] \\
\hline
\end{tabular}


Table 4. Cont.

\begin{tabular}{|c|c|c|c|c|c|}
\hline Waste & Scientific Name & Plant Part & Method of Identification & Compounds & Reference \\
\hline Red grape & $\begin{array}{l}\text { Vitis vinifera (cv. Sangiovese } \\
\text { and Montepulciano) }\end{array}$ & Pomace & HPLC-DAD & $\begin{array}{l}\text { Quercetin, rutin, cis-piceid, catechin, epicatechin, epigallocatechin } \\
\text { gallate, epicatechin gallate, epigallocatechin, gallic acid, vanillin, } \\
\text { vanillic acid }\end{array}$ & [196] \\
\hline Red grape & $\begin{array}{l}\text { Cultivars Chambourcin } \\
\text { (hybrid), Merlot (Vitis } \\
\text { vinifera), Norton (Vitis } \\
\text { aestivalis), Petit Verdot }(V \text {. } \\
\text { vinifera), Tinta Cao }(\text { V. vinifera })\end{array}$ & Pomace & HPLC-DAD & $\begin{array}{l}\text { Malvidin chloride, gallic acid, catechin, delphinidin chloride, } \\
\text { caffeic acid, cyanidin chloride, p-coumaric acid, epicatechin gallate, } \\
\text { rutin, quercetin-3-O-glucoside, myricetin, resveratrol, quercetin } \\
\text { hydrate, kaempferol }\end{array}$ & [197] \\
\hline Pistachios & Pistacia vera $\mathrm{L}$. & Shell skin & RP-HPLC-DAD & $\begin{array}{l}\text { Gallic acid, protocatechuic acid, }(+) \text {-catechin, p-hydroxybenzoic } \\
\text { acid, caffeic acid, (-)-epicatechin, syringic acid, p-coumaric acid, } \\
\text { hesperidin, quercetin, apigenin }\end{array}$ & [198] \\
\hline White grape & Vitis vinifera & Peel & $\begin{array}{l}\text { UPLC-DAD-MS and } \\
\text { MALDI-TOF-MS for } \\
\text { proanthocyanidins }\end{array}$ & $\begin{array}{c}\text { Catechin, epicatechin, quercetin-3-O-glucuronide, } \\
\text { quercetin-3-O-glucoside, quercetin-3-O-rhamnoside, } \\
\text { kaempferol-3-O-galactoside, kaempferol-3-O-glucuronide, } \\
\text { kaempferol-3-O-glucoside, quercetin, kaempferol, oligomeric } \\
\text { proanthocyanidins }\end{array}$ & [199] \\
\hline Jackfruit & Arpus heterophyllus Lam. & Peel & HPLC-QTOF-MS/MS & $\begin{array}{c}\text { Cis-3-caffeoylquinic acid, trans-3-caffeoylquinic acid, } \\
\text { esculetin-O-hexoside, esculetin- } C \text {-hexoside, 3,4-dihydroxybenzoic } \\
\text { methyl ester- } C \text {-dihexoside, esculetin-hexoylpentoside, } \\
\text { feruloylglucoside, cis-3-caffeoylquinic acid, caffeoylglucoside, } \\
\text { cis-5-caffeoylquinic acid, trans-5-caffeoylquinic acid, } \\
\text { trans-4-caffeoylquinic acid, procyanidin B, epicatechin, } \\
\text { dihydroquercetin, prenyl-O-naringenin, prenylgenistein, } \\
\text { pentenylnaringenin, hexenyl-5,7,4'-trihydroxyflavan }\end{array}$ & [200] \\
\hline
\end{tabular}


Another valorization study performed by Carullo et al. [195] aimed to enrich milk kefir with a red grape cv. Sangiovese pomace extract during preparation to enhance the antioxidant potential of the product. Grape pomace extracts used in the experiments were rich in (+)-catechin and (-)-epicatechin with concentrations of 105 and $76 \mathrm{mg} / \mathrm{mL}$, respectively. Furthermore, pomace-enriched kefir milk enhanced the total phenolic content and the antioxidant capacity of kefir. Additionally, pomace treatments improved the inhibitory capacity of carbohydrate and lipid metabolic enzymes like $\alpha$-amylase, $\alpha$-glucosidase, and pancreatic lipase. However, the inhibitory rate of enriched-kefir milk is significatively lower than that of acarbose and Orlistat. On the other hand, the inhibition of lipase, $\alpha$-amylase, and $\alpha$-glucosidase was achieved in a potential functional product recommended for regular intake, which might prevent diseases like diabetes and metabolic syndrome.

Another study using pomace as a functional ingredient was published by Urquiaga, Troncoso, Mackenna, Urzua, Perez, Dicenta, de la Cerda, Amigo, Carreno, Echeverria, and Rigotti [23]. They incorporated wine grape pomace to beef burgers in an attempt to improve antioxidant and metabolic syndrome parameters. The studies were performed in a three-month intervention study, with 27 male volunteers with metabolic syndrome. These individuals were administered one daily pomace-supplemented burger, which had significantly higher phenolic and dietary fiber content (1.21 mg gallic acid equivalents/g and $3.5 \mathrm{~g}$, respectively) than those of control burgers $(0.396 \mathrm{mg}$ gallic acid equivalents/g and $0 \mathrm{~g}$, respectively). Red grape pomace burgers improved metabolic syndrome factors like improved glycemia, enhanced the insulin sensibility, and decreased oxidative stress (lowered oxidized low-density lipoprotein content, reduce advanced oxidation protein products, and lower malondialdehyde content); furthermore, antioxidant enzymes were also enhanced. The report by Ambigaipalan, et al. [189] showed pomegranate peel extracts exert inhibitory properties against $\alpha$-glucosidase and pancreatic lipase. In this sense, the esterified peel extracts showed higher inhibitory rates against the enzymes with IC50 values of 0.99 and $10.77 \mathrm{mg} / \mathrm{mL}$ extracts for $\alpha$-glucosidase and lipase, respectively. The major phenolic compounds in pomegranate peel were gallic acid and kaempferol-3-O-glucoside; these compounds were associated with the enzymatic inhibition. However, previous reports have suggested that gallic acid is not a strong inhibitor of $\alpha$-glucosidase, whereas kaempferol (and some of its derivates) is a better inhibitor [185]. Hence, the enzymatic inhibition might be attributed to a synergistic effect of the phenolics present in the pomegranate peel extracts. Colantuono, Ferracane, and Vitaglione [20] evaluated the bioaccessibility and anti-obesity potential of cookies, where the dough was enriched with $5 \mathrm{~g}$ of pomegranate peel. The phenolics from pomegranate peel-enriched cookies had high contents of punicalagin, ellagic acid, castalagin, and punicalin at the beginning of the gastrointestinal digestion; moreover, overall, the most abundant compounds were ellagitannins, followed by ellagic acid derivates. Furthermore, at the end of the gastrointestinal digestion, the most bioaccessible phenolics were ellagic acid and castalagin with concentrations of 33.5 and $16.3 \mathrm{mg} / 100 \mathrm{~g}$, respectively. The pomegranate peel-enriched cookies' enzyme inhibitory capacity at the duodenal phase of the gastrointestinal digestion showed inhibition of $\alpha$-glucosidase by $84 \% \alpha$-amylase and lipase were inhibited by $72 \%$ and $13 \%$, respectively.

El-Hadary and Ramadan [190] also evaluated the potential of pomegranate peel extracts against metabolic syndrome factors and diabetes. The authors performed an in-vivo study with alloxan-induced diabetic adult Wister albino rats orally administered $200 \mathrm{mg} / \mathrm{kg}$ of the peel extract daily for 56 days. The major phenolics in pomegranate peel extracts were punicalagin, pyrogallol, and ellagic acid. After 56 days, extracts from pomegranate waste decreased the levels of blood glucose, total lipid cholesterol, LDL-C, and glycosylated hemoglobin levels. The authors attributed this effect to a possible synergistic action of the phenolic compound in the pomegranate extracts.

Islam et al. [201] evaluated the $\alpha$-glucosidase inhibitory potential of mango, jackfruit, pineapple, papaya, litchi, and banana peels of extracts obtained by organic solvent, pressurized hot water, and enzymatic-assisted (using Viscozyme L, a mixture of arabinose, cellulase, $\beta$-glucanase, hemicellulase, and xylanase) extraction. The authors reported that all the fruit peel extracts had $\alpha$-glucosidase inhibitory activity in a dose-dependent manner and that this inhibition was species and 
cultivar-dependent. Additionally, in some cases, the extraction method also showed a significant effect on the enzymatic inhibitory capacity of the extracts, which the authors correlate to the yield of phenolic acids and flavonoids in the extracts. However, the phenolic compounds were not identified by any chromatographic analysis. Pistachio shell skin is another by-product that has been used in food waste valorization studies. Kilic et al. [198] showed that pistachio shell skins are a source of phenolic acids and flavonoids. The most abundant compounds were p-hydroxybenzoic acid, protocatechuic acid, (-)-epicatechin, quercetin, apigenin, and quercetin. Pistachio waste showed $\alpha$-amylase inhibition in both mature and immature shell skin (3.72 and $4.91 \mathrm{mg}$ of acarbose equivalents/g of extract, respectively). However, it did not show any $\alpha$-glucosidase inhibition.

Goss et al. [191] showed the antidiabetic potential of peel flour of Passiflora edulis Var. Flavicarpa rich in caffeic acid and isoorientin (luteolin-6-C-glucoside) in male Wistar rats supplied with $10 \%$ fructose (to simulate the intake of approximately $600 \mathrm{~mL}$ of high fructose soda) and supplemented with 30\% P. edulis peel flour extract. It was shown that Passiflora treatment prevented some factors related to the intake of high-fructose beverages; for instance, treatments prevented the apparition of insulin resistance, increased serum triglycerides levels, the growth of fat adiposities in the liver, and widening of adipocytes. Thus, it is suggested that $P$. edulis can be used as a functional ingredient to prevent insulin resistance and hepatic steatosis in rats. Further studies are needed to extrapolate these results to humans.

Moreover, Henriquez, et al. [202] used Granny Smith apple peel as a source of bioactive compounds, like phenolics and dietary fiber, to enrich some food formulations. The authors incorporated the apple peel powder into the formulations of muffins and puree. The concentrations of apple powder used were $5.3 \%$ for apple puree and $14.3 \%$ for the muffins. The incorporation of apple peel significantly increased the content of insoluble, soluble, and total dietary fiber in both muffins and puree. The treatments also increased the antioxidant capacity of both food products. Moreover, apple peel incorporation increased the $\alpha$-glucosidase inhibitory capacity of muffins from $7.69 \%$ to $33.18 \%$; the $\alpha$-amylase inhibitory also increased from $22.58 \%$ to $35.54 \%$, which might be detrimental as it has been reported that concomitant inhibition of $\alpha$-glucosidase and $\alpha$-amylase can cause gastrointestinal discomfort [203]. However, this effect was not observed for the enriched-apple puree, which also showed higher enzyme inhibitory rates, which might be associated with the formulation of the product even without apple peel-enrichment.

Several cultivars of white grape peel obtained from pomace were evaluated by Lavelli et al. [199]. The UPLC-DAD-MS analysis showed that peel extracts are a rich source of oligomeric proanthocyanidins composed of catechin-epicatechin units and gallic acid ester derivatives. Moreover, these extracts' inhibitory activity on $\alpha$-glucosidase ranged from IC50 values of 30.9-93.1 $\mu \mathrm{g}$ gallic acid equivalents $/ \mathrm{mL}$. On the other hand, the extracts showed higher $\alpha$-amylase with IC50 values from 12.5 to $27.4 \mu \mathrm{g}$ gallic acid equivalents/mL. As previously mentioned, it might be detrimental, as higher amylase inhibition might cause gastrointestinal discomfort [203]. The peel from different citrus plants was evaluated by Lim and Loh [204]. The authors assessed the peels of white Tambun pomelo, kaffir lime, lime, and calamansi. It was reported that methanolic extracts from the samples inhibit both $\alpha$-glucosidase and $\alpha$-amylase, where calamansi bound compounds and white Tambun pomelo free extracts had the highest $\alpha$-glucosidase inhibition with $43.99 \%$ and $41.06 \%$, respectively. The authors did not identify the phenolics in the sample by any chromatographic instrument.

Ling, et al. [205] evaluated the hypolipidemic potential of the peel of citrus Changshan-huyou in male LVG Syrian golden hamsters fed with a high-fat diet for two weeks and then administered with 25 , 50 , and $100 \mathrm{mg} / \mathrm{kg}$ of Changshan-huyou citrus peel. The treated animals showed a significant decrease in serum levels in a dose-dependent manner of total cholesterol, total triglycerides, and lower content of low-density lipoprotein cholesterol. However, citrus peel did not affect body weight. Moreover, the authors also showed that citrus peel treatment attenuated the parameters related to pathological liver steatosis (like decreased alanine transaminase, aspartate transaminase, and alkaline phosphatase) and less inflammatory infiltration (by reduced levels of TNF- $\alpha$ and IL-6) in a dose-dependent manner. 
It was suggested that the bioactive effect of Changshan-huyou peel might be partially attributed to the main flavonoids found in the peel samples like naringin, narirutin, and neohesperidin. Peanut skin has also shown hypolipidemic properties as reported by Toomer et al. [206], who tested the hypolipidemic potential of methanol extracts of peanut skins from blanched Runner type peanuts on adult male C57BL6/J mice. Peanut peel extract was incorporated into the mice's diet at $0.78 \%$ by weight, aiming to contain $130 \mathrm{mg}$ polyphenols/kg body weight/day. Peanut peel improved body weight and reduced hepatic cholesterol levels and lipid storage. Even though the authors did not report any chromatographic identification of phenolic compounds, it has been reported that peanut peel is rich in procyanidins, to which the effects, as mentioned earlier, might be attributed. Peel extracts of Vitis vinifera L. rich in peonidin-3-O-glucoside, petunidin-3-O-glucoside, malvidin-3-O-glucoside, and malvidin-3-(6-O-trans-p-coumaryl)-5-O-diglicoside were proven to improve metabolic syndrome factors in high-fat diet-fed C57BL/6 male mice [15]. In this sense, the research by Santos, de Bem, Cordeiro, da Costa, de Carvalho, da Rocha, da Costa, Ognibene, de Moura, and Resende [15] incorporated $200 \mathrm{mg} / \mathrm{kg}$ of grape peel extracts orally administered to mice for 12 weeks. In contrast to non-treated mice, peel extracts prevented both the development of hyperglycemia and increased insulin levels during the treatment. Peel treatment also prevented body weight gain and the development of hepatic steatosis in mice.

Although valorization studies have been reported in the last five years regarding the antidiabetic and anti-obesity capacity of bioactive compounds like phenolics from pomace and peel waste, most studies do not evaluate the cellular and molecular mechanisms of action of the reported potential pharmacological effect. Most of the reported biological properties of phenolic compounds are attributed to their antioxidant activity and their capacity to form nonspecific complexes with target proteins involved in many non-communicable diseases like cancer, cardiovascular diseases, and diabetes [207]. The interactions between phenolic compounds and biological proteins are mediated through hydrophobic $\pi$-stacking interactions stabilized by hydrogen bonds or by the addition of nucleophiles to oxidize quinones. Additionally, some studies suggest that proline residues are essential to protein-phenolic binding $[189,207,208]$. The enzymatic mechanisms of action of phenolic compounds on carbohydrate and lipid metabolic enzymes have been previously studied. For instance, Xiao, Kai, Yamamoto, and Chen [185] state that the hydroxylation and galloylation of flavonoids improve the $\alpha$-glucosidase inhibitory capacity of phenolic compounds and that caffeoylquinic acids show strong inhibitory capacity. However, some phenolic acids like hydroxycinnamic acid, ferulic acid, and gallic acid are not suitable inhibitors. The degree of glycosylation and hydroxylation also affects the inhibitory capacity of phenolics [185]. Moreover, the authors also report that phenolic compounds inhibit $\alpha$-glucosidase in a non-competitive manner.

Furthermore, scientists evaluated pancreatic lipase inhibition by natural compounds, because obese patients are more commonly treated with Orlistat, a drug that inhibits pancreatic lipase. However, natural alternatives are sought due to this medication's adverse effect, such as gastrointestinal discomfort, steatorrhea, oily feces, fecal incontinence, and potentially liver damage [209]. Zhou, Zhou, Liu, Zhang, and Cai [33] performed a docking analysis on the inhibitory capacity of caffeic acid and catechin against pancreatic lipase. Their computational analysis using the software SYBYL-X 2.1.1 showed that catechin has more affinity towards the enzyme, as catechin binds to pancreatic lipase with the amino acid residues Ala197, Pro194, Ser195, and Lys198 at the active site by hydrogen bonds. On the other hand, caffeic acid binds to the amino acid residues Ala197, His224, and Lys198 at the active site. However, caffeic acid shows shorter hydrogen bond distances than catechin, which usually represent tight bounds and stronger inhibitory ability [33].

Moreover, as stated by Urquiaga, Troncoso, Mackenna, Urzua, Perez, Dicenta, de la Cerda, Amigo, Carreno, Echeverria, and Rigotti [23], vegetable waste such as grape pomace contains a variety of bioactive potential antidiabetic constituents such as dietary fiber, phenolic acids, and flavonoids. This makes it difficult to understand the precise mechanisms of action, as the experiments' results might be the response of a synergistic effect of the bioactive components. Furthermore, the possible 
association of the chemical components of pomace with the food matrix of the product formulation might affect the bioaccessibility and bioavailability of the pomace phenolic compounds. The food matrix has been reported as a factor that affects the bioaccessibility of phenolic compounds, since the $-\mathrm{OH}$ radical of the phenolics might form a possible interaction between the elements of dietary fiber or proteins $[78,210]$. Furthermore, the gastrointestinal tract is an environment that facilitates the formation of free radicals and reactive oxygen species. Lipid-rich foods might promote the production of lipid peroxidation and oxidation of dietary proteins. This is intriguing, since reactive species and free radicals have been associated with the development of obesity and diabetes comorbidities [211]. Thus, pomace-enriched food products might prevent damage by oxidative stress caused by food constituents and thus act as chemopreventive agents.

Overall, preliminary valorization studies show that peels from vegetable waste are a rich source of phenolic acids and flavonoids and that extracts from these samples can inhibit enzymes involved in the treatment of diabetes and metabolic syndrome. Furthermore, studies are limited to in vitro techniques, and in some rare cases, the experiments asses in vivo studies. Each report also shows different concentrations used in each assay; this makes comparison difficult and limits further studies. Moreover, systematic studies incorporating metabolomic and bioavailability studies are needed to assess the true antidiabetic, anti-obesity, and antimetabolic syndrome potential of vegetable waste, as well as toxicity and pharmacokinetic studies.

\subsection{Anti-Hypertensive}

One of the key risk factors for developing cardiovascular disease is a persistent elevation in blood pressure above 140/90 $\mathrm{mm} \mathrm{Hg}$. This has led to strategies aimed at finding molecules capable of lowering high blood pressure. In this sense, among the several natural products, phenolic compounds and bioactive peptides have been described with antihypertensive activity. Bioactive peptides can act by inhibiting the activity of ACE and renin, thus lowering blood pressure. Most studies report angiotensin-converting enzyme (ACE, EC 3.4.15.1) inhibitory properties. The ACE enzyme participates in different blood pressure regulatory mechanisms by converting angiotensin I into the potent vasoconstrictor angiotensin II and eliminating the vasodilator effects of bradykinin through its degradation [212]. Figure 2 (own elaboration) shows the systems that regulate vasodilation and vasoconstriction, as well as the changes associated with the presence of ACE inhibitors. The renin-angiotensin-aldosterone system plays an important role in the physiological mechanism to regulate blood pressure; it includes the transformation of angiotensinogen into angiotensin I, a process that is catalyzed by renin secreted in the kidneys through the action of tissue and plasma kallikrein, responsible also for the increase in bradykinin that acts as a vasodilator, which in the presence of ACE is inactivated, generating mainly bradykinin 1-7 (Figure 2); and angiotensin I is converted into angiotensin II (a potent vasoconstrictor) by the action of ACE (produced, for example, in lung tissue); at the same time, this enzyme converts the vasoconstrictor (Figure 2). Therefore, if a compound capable of inhibiting ACE activity is used, vasoconstriction is decreased, and the concentration of the active form of vasodilator is increased, which results in a decrease in blood pressure. Currently, synthetic ACE inhibitors such as captopril, ramipril, enalapril, lisinopril, and alacepril are widely used, but these medications are associated with various side effects, including coughing and angioedema, as well as other like rashes and reduced kidney function [213]. Therefore, in recent years, interest has grown to seek natural alternatives for antihypertensive compounds, with bioactive peptides of food origin being the most promising until now. In this sense, it has been reported that the enzymatic hydrolysis of proteins of vegetable waste are a rich source of bioactive peptides with hypotensive properties (Table 5). These matrices include press cakes and meals from the extraction oils from coconut [32], sweet almonds [214], walnuts [215], and rapeseed [27,216,217]; cauliflower leaves and stems [129,218]; asparagus waste [219]; cherry waste [182]; seeds from olive [220], tomato [29], plum [26] and peach [30]; date seed flour [181]; wheat bran [221], broken rice [222], quinoa, and kiwicha [223]; barley after being used in brewing beer [224]; beans [225]; and peanut [226]. Most of these bioactivity studies 
are performed in vitro, but there are evaluations of peptides with antihypertensive activity in vivo using spontaneously hypertensive rats (SHR) as a model. In this way, some peptides from a different matrix have been evaluated. In a study, three peptides from hydrolyzed broccoli protein with ACE inhibitory activity in vitro and hypotensive effect in vivo were isolated and identified; one of them, LVLPGELAK ( $\mathrm{IC}_{50}$ value $184 \mu \mathrm{M}$ ) generated two new peptides simulating digestion: LVLPGE and LAK, both with high ACE inhibitory activity ( $\mathrm{IC}_{50}$ values of 13.5 and $48.0 \mu \mathrm{M}$, respectively). LVLPGE caused a greater decrease in blood pressure in SHR after one hour of oral administration $(10 \mathrm{mg} / \mathrm{kg}$ of body weight) compared to captopril ( $5 \mathrm{mg} / \mathrm{kg}$ of body weight) [12]. The peptide IYSPH with ACE inhibitory activity $\left(\mathrm{IC}_{50}\right.$ value $\left.39.5 \mu \mathrm{M}\right)$ obtained by hydrolysis of peach seed proteins is capable of causing a significant reduction in systolic blood pressure $(-30 \mathrm{mmHg})$ in SHR after three to six hours of treatment [30]. On the other hand, rapeseed meal from the oil extraction industry can be used to obtain different bioactive peptides, among which the dual ACE/renin inhibitor peptides stand out: LY, RALP, and GHS, which were administered via oral for five weeks at SHR, providing hypotensive effects through mechanisms involving modulation of the expression of key enzymes and intermediates of the renin-angiotensin system, such as ACE, ACE2, Ang II, and Ang- (1-7) [27].

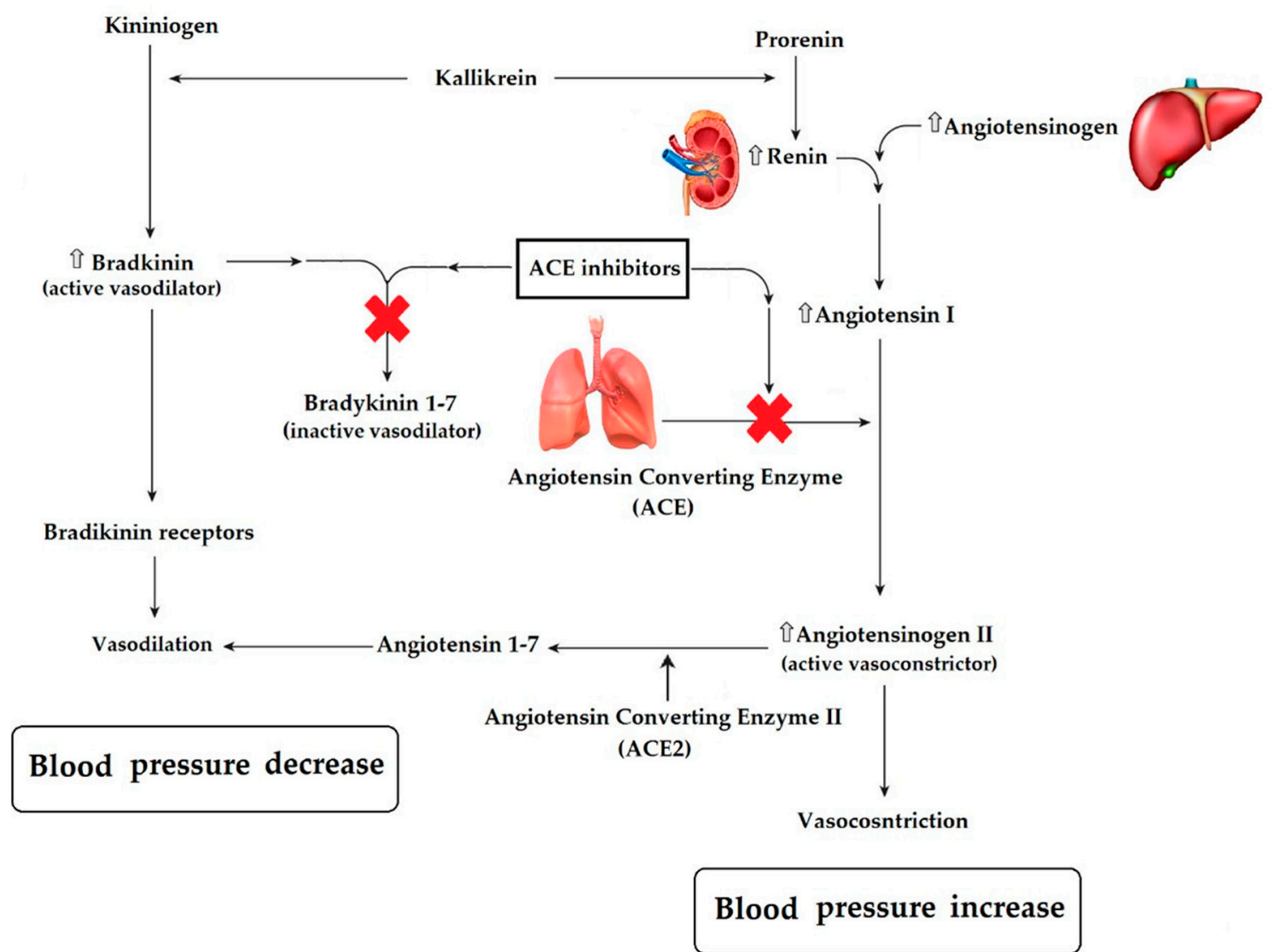

Figure 2. General effects on blood pressure regulation by Angiotensin-Converting Enzyme (ACE) Inhibitors. 
Table 5. Antihypertensive peptides obtained by enzymatic hydrolysis from waste of vegetable food matrices.

\begin{tabular}{|c|c|c|c|c|}
\hline Waste & Source or Matrix & Enzymes or Hydrolysis Conditions & Peptide Sequence $^{a}\left(\mathrm{IC}_{50}\right)^{b}$ & Reference \\
\hline \multirow[t]{4}{*}{$\begin{array}{l}\text { Proteins from oils } \\
\text { manufacturing }\end{array}$} & Coconut cake albumin & $\begin{array}{l}\text { Alcalase, flavourzyme, pepsin, and } \\
\text { trypsin (sequential hydrolysis) }\end{array}$ & $\begin{array}{c}\text { KAQYPYV (37.06 mM) } \\
\text { KIIIYN (58.72 mM) } \\
\text { KILIYG (53.31 mM) }\end{array}$ & {$[32]$} \\
\hline & Walnut (Juglans regia L.) meal & Pepsin & YEP $(0.29 \mu \mathrm{M})$ & [215] \\
\hline & Rapeseed meal & Alcalase & $\begin{array}{c}\text { LY }\left(0.11 \mathrm{mM}, 1.87 \mathrm{mM}^{*}\right) \\
\text { TF }(0.81 \mathrm{mM}) \\
\text { RALP }\left(0.65 \mathrm{mM}, 0.97 \mathrm{mM}^{*}\right) \\
\text { GHS }\left(1.74 \mathrm{mM}^{*}\right)\end{array}$ & {$[27,216,217]$} \\
\hline & Sweet almond (Prunus armeniaca L.) & Alcalase & $\begin{array}{l}\text { MHTDD }(7.52 \mu \mathrm{g} / \mathrm{mL}) \\
\text { GHTDD }(43.18 \mu \mathrm{g} / \mathrm{mL})\end{array}$ & [214] \\
\hline \multirow[t]{4}{*}{ Vegetable waste } & $\begin{array}{l}\text { Cauliflower (Brassica oleracea L. var. } \\
\text { botrytis) leaves and stems }\end{array}$ & Alcalase & $\begin{array}{l}\text { APYDPDWYYIR }(2.59 \mu \mathrm{M}) \\
\text { SKGFTSPLF }(15.26 \mu \mathrm{M})\end{array}$ & [129] \\
\hline & & & $\mathrm{VT}(31.30 \mu \mathrm{M})$ & [218] \\
\hline & Asparagus (Asparagus officinalis) & Alcalase & $\begin{array}{c}\text { PDWFLLL }(1.76 \mu \mathrm{M}) \\
\text { ASQSIWLPGWL }(4.02 \mu \mathrm{M})\end{array}$ & [219] \\
\hline & $\begin{array}{c}\text { Broccoli (Brassica oleracea var. italica cv. } \\
\text { Lvxiong 90) }\end{array}$ & Chymotrypsin & $\begin{array}{c}\text { IPPAYTK }(23.5 \mu \mathrm{M}) \\
\text { LVLPGELAK }(184.0 \mu \mathrm{M}) \\
\text { TFQGPPHGIQVER }(3.4 \mu \mathrm{M}) \\
\text { LVLPGE }(13.5 \mu \mathrm{M}) \\
\text { LAK }(48.0 \mu \mathrm{M}) \\
\end{array}$ & [12] \\
\hline \multirow{2}{*}{$\begin{array}{l}\text { Seeds and others waste from } \\
\text { peeler/pitting process on fruits }\end{array}$} & Peach seed proteins & Thermolysin & IYSPH $(39.5 \mu \mathrm{M})$ & [30] \\
\hline & Olive (Olea europaea L.) seed proteins & Thermolysin & LLPSY $(39.9 \mu \mathrm{M})$ & [220] \\
\hline
\end{tabular}


Table 5. Cont.

\begin{tabular}{|c|c|c|c|c|}
\hline Waste & Source or Matrix & Enzymes or Hydrolysis Conditions & Peptide Sequence ${ }^{a}\left(\mathrm{IC}_{50}\right)^{b}$ & Reference \\
\hline \multirow{11}{*}{$\begin{array}{l}\text { Cereals, pseudocereals, and } \\
\text { legumes industry }\end{array}$} & Cherry (Prunus Cerasus L.) by products & Thermolysin & n.r. $(0.31 \mathrm{mg} / \mathrm{mL})$ & [182] \\
\hline & Plum (Prunus domestica L.) seed & Thermolysin & n.r. $(22.8 \mu \mathrm{g} / \mathrm{mL})$ & [26] \\
\hline & Date (Phoenix dactylifera L.) seed flour & Alcalase and Thermolysin & n.r. $(0.53 \mathrm{mg} / \mathrm{mL})$ & [181] \\
\hline & Tomato seeds & Bacillus subtilis Fermentation & DGVVYY $(2 \mu \mathrm{M})$ & [29] \\
\hline & Wheat bran & Alcalase & NL, QL, FL, HAL, AAVL, AKTVF, TPLTR & [221] \\
\hline & Quinoa (Chenopodium quinoa) & Neutrase & n.r. $(0.08 \mathrm{mg} / \mathrm{mL})$ & [223] \\
\hline & Kiwicha (Amaranthus caudatus) & Alcalase-Neutrase (sequential hydrolysis) & n.r. $(0.29 \mathrm{mg} / \mathrm{mL})$ & \\
\hline & Broken rice & Pepsin & n.r. $(0.87 \mathrm{mg} / \mathrm{mL})$ & [222] \\
\hline & Rice (Oyaza sativa) bran & Tripsyn & YSK $(76 \mu \mathrm{M})$ & [31] \\
\hline & Azufrado beans (Phaseolus vulgaris L.) & Alcalase & KFPWVK, GADFRKK, PQSPCKRVNRHS & [227] \\
\hline & Lima bean (Phaseolus lunatus) & $\begin{array}{c}\text { Alcalase } \\
\text { Flavourzyme }\end{array}$ & $\begin{array}{l}\text { n.r. }(30.3 \mu \mathrm{g} / \mathrm{mL}) \\
\text { n.r. }(51.8 \mu \mathrm{g} / \mathrm{mL})\end{array}$ & [225] \\
\hline \multirow{2}{*}{$\begin{array}{l}\text { Brewing industry: Brewers' } \\
\text { spent grain }\end{array}$} & Peanut (Arachis hypogaea) & Alcalase & KLYMRP $(6.42 \mu \mathrm{M})$ & [226] \\
\hline & Barley & $\begin{array}{c}\text { Alcalase, Corolase PP, Flavourzyme and } \\
\text { Promod 144MG }\end{array}$ & $\begin{array}{l}\text { IVY }(80.4 \mu \mathrm{M}) \\
\text { ILDL }(96.4 \mu \mathrm{M})\end{array}$ & [224] \\
\hline
\end{tabular}

a Peptide sequences with ACE inhibition activity checke; n.r. not reported, generally the activity was assessed in fractions. ${ }^{\mathrm{b}}$ IC50 $=$ necessary concentration to inhibit $50 \%$ the ACE activity, determined by in-vitro test. * IC50 of ACE inhibition activity assessed in-vivo. 
Currently, the potential use of some waste of cereals and pseudocereals to obtain bioactive peptides has been studied; consequently, a peptide fraction $<1 \mathrm{KDa}$ composed of seven peptides (NL, QL, FL, HAL, AAVL, AKTVF, and TPLTR) from a hydrolyzed wheat bran protein was evaluated; the fraction inhibited ACE and renin (in vitro $1 \mathrm{mg} / \mathrm{mL}$ of fraction have inhibition values of $84.25 \%$ and $75.19 \%$, respectively) when administered orally in SHR $(100 \mathrm{mg} / \mathrm{kg}$ of body weight), which resulted in a decrease in systolic blood pressure $(-35 \mathrm{mmHg})$ after $6 \mathrm{~h}$ of treatment [221]. In other studies, the feasibility of using rice waste has been reported; in one of them, it was found that the protein hydrolysis of rice bran can generate the tripeptide Tyr-Ser-Lys with high ACE inhibition activity [31]; for broken rice (an underused industrial by-product), it was determined that it is possible to generate peptides with antihypertensive activity by hydrolysis with pepsin, achieving the isolation by RP-HPLC of two fractions $(<1.5 \mathrm{KDa})$ capable of inhibiting the ACE and renin activity. Both fractions were characterized by molecular coupling studies and indicated that the octapeptide SPFWNIN had the highest inhibitory potential [222]. Additionally, an in-silico prediction has been made to determine the use of oats as a source of antihypertensive peptides, concluding that it is possible to synthesize nine novel peptides with different efficacy in the inhibition of enzymes involved in the regulation of blood pressure such as ACE (48.9-97.8\%), renin (0-17.1\%), and DPP-IV (0-22.2\%) [228]. Others evaluated in vitro the antihypertensive properties (inhibition of ACE-I) of quinoa and kiwicha protein hydrolysates obtained by enzymatic hydrolysis with $\mathrm{IC}_{50}$ values of 08 and $0.29 \mathrm{mg} / \mathrm{mL}$, respectively, with stable bioactive properties after simulated gastrointestinal digestion [223] so the use of waste that could be generated in its industrialization is promising.

\subsection{Anti-Cancer}

Cancer is characterized by an uncontrolled cell proliferation, which occurs when genes controlling cell growth and apoptosis are damaged. The induction of apoptosis is a target for anticancer therapy [229]. Two pathways lead to apoptosis: the intrinsic mitochondria-mediated pathway and the extrinsic pathway. The Bax/Bcl-2 ratio mediates the mitochondrial apoptotic pathway. Bax is a proapoptotic protein, while Bcl-2 inhibits cell apoptosis. An increase in the Bax/Bcl-2 ratio causes permeability of the mitochondria and release of cytochrome $\mathrm{c}$ to the cytosol, causing caspases (Caspase 3 and 9) activation and the apoptotic response [22,230]. The extrinsic pathway is by extracellular ligands through cognate death receptors such as tumor necrosis factor receptors (TNFR) associated factors (TRAFs). TRAFs regulate the activation of nuclear factor $\mathrm{KB}(\mathrm{NF}-\mathrm{kB})$ and mitogen-activated protein kinases (MAPKs). NF- $\mathrm{kB}$ in normal conditions is inactivated in the cytoplasm, forming a complex with a family of inhibitory proteins, inhibitory $\kappa B s$ (I $\kappa B s)$, which includes I $\kappa B \alpha$ and $\operatorname{I} \kappa B \beta$. However, in tumors, NF- $\mathrm{KB}$ is frequently activated and involved in tumor growth and progression. In this sense, the activation of NF- $\kappa B$ is induced by signals of degradation (phosphorylation) of I $k B$ s, particularly of $\mathrm{I} \kappa \mathrm{B} \alpha$, promoting the NF- $\mathrm{kB}$ nuclear translocation. Consequently, the expression of antiapoptotic genes; therefore, NF-kB is an important therapeutic target in cancer $[13,231,232]$. Both the intrinsic and extrinsic pathways use caspases to carry out apoptosis. These proteins are divided in initiator (caspase-2,-8,-9 and -10) and executioner (caspase-3,-6 and -7) caspases [230].

Cell proliferation, angiogenesis, and metastasis are also key factors in cancer development. Cell proliferation depends on four distinct phases of the cell cycle (G0/G1, S, G2, and M), regulated by cell cycle proteins (cyclins and cyclin-dependent kinases, CDKs). CDKs inhibition led to cell cycle phases arrest and provoked tumor cell senescence or apoptosis. For example, the inhibiting of CDK1 and cyclin B induce cell cycle arrest at G2/M phase [233]. The G2/M phase arrest prevents cells from entering mitosis when DNA is damaged [234]. Therefore, CDKs and cyclins are considered a target in anticancer therapy [233]. On the other hand, angiogenesis plays an important role in tumor growth, maintenance, and metastasis. Angiogenesis is regulated by pro-angiogenic factors, including vascular endothelial growth factor (VEGF) and metalloproteinases (MMPs) such as MMP-2, MMP-9, and MMP-14 [235,236]. MMPs can also promote metastasis, cell migration, and cancer development [237]. 
In-vivo and in-vitro studies have reported that terpenes and phytosterols extracted from plants can be used as anticancer therapeutics on various types of cancer due to induce apoptosis and inhibit tumor growth and metastasis through extrinsic and intrinsic pathways, regulation of cyclin-dependent kinases and preventing of angiogenesis. Studies on antitumor effects of terpenes extracted from plants have been reported. For example, a mixture of sesquiterpenoids ( $\beta$-caryophyllene, $\alpha$-humulene, humulene epoxide I, valencene, epi- $\alpha$-selinene, $\gamma$-muurolene, $\alpha$-aryphyllene-oxide, and trans-nerolidol) of essential oil extracted from Myrica rubra inhibits proliferation and induces apoptosis by the increase of caspase 8 and 9 and effector caspases 3/7 in human colon carcinoma cell line (Caco-2) [65]. Menon and Gopalakrishnan [238] indicated that a combination of mono and sesquiterpenes isolated from Plectranthus hadiensis induce apoptosis in the HCT-15 cell line through the increase in the expression of proapoptotic proteins Bax and capase 3 and the decrease antiapoptotic protein Bcl-2 via the mitochondria-mediated pathway. Lee et al. [239] demonstrated that $\beta$-myrcene from Pinus koraiensis cones at a concentration of $100 \mu \mathrm{M}$ might promote anti-metastatic activity in MDA-MB-231 via downregulation of NF-kB-mediated by MMP-9 expression. A more recent study reported that terpenoids extracted from the essential oil of leaves of Teucruim alopecurus such as $\alpha$-Bisabolol, $(+)$-epi-Bicyclosesquiphellandrene, and $\alpha$-Cadinol exert their anticancer effect in human myeloid leukemia (KBM-5) through inhibition of the NF- $\mathrm{KB}$ activation mediated by the reduction of the phosphorylation of $I_{\kappa} B \alpha$, downregulating the expression of proteins involved to cell angiogenesis (VEGF) and metastasis (MMP9) [13]. An in vivo study reported that oral administration $(0.58 \mathrm{~g} / \mathrm{kg}$ body weight/day for 13 days) of a combination of monoterpenes ( $\alpha$-pinene and myrcene) of mastic oil extracted from the resin of Pistacia lentiscus inhibits the growth of colon carcinoma tumors in Balb/c mice [240]. Hou, Zhang, Zhu, Zhou, Ren, Liang, and Guo [21] revealed that $\alpha$-pinene extracted from the essential oil of leaves of Boswellia dalzielii induced apoptosis by increasing the apoptotic enzyme capase- 3 and inhibiting the cell proliferation by $\mathrm{G}_{2} / \mathrm{M}$ phase arrest in PA- 1 human ovarian cancer cell lines.

Recent studies have shown the potential of phytosterols to alleviate breast, ovary, colon, bile duct, and cervical cancer. Stigmasterol, combined with doxorubicin encapsulated within the nano-hybrid liposome system, inhibits tumor growth in the MDA-MB-231 (breast cancer cell line) xenograft tumor model [14]. In vitro, stigmasterol induces the apoptosis in human ovarian cancer cell lines (ES2) by the increase in the mitochondrial depolarization; inhibition of PI3K/MAPK signal cascades, which are frequently activated in ovarian cancer and thus are pivotal in cancer cell proliferation; decrease MMPs (MMP2, MMP9, and MMP14) expression levels and VEGFA: increase of endoplasmic reticulum stress-sensor protein levels and inhibition of the cell cycle progression [241]. Intraperitoneal administration $(10 \mathrm{mg} / \mathrm{kg})$ of lupeol or stigmasterol or a combination of both phytosterols suppress the growth tumor of human cholangiocarcinoma xenograft models in nude mice by disrupting the growth and migration of the host endothelial cells and consequently preventing the tumor angiogenesis [242]. There are few reports on the anticancer effect of phytosterols extracted from plants, which show that these natural compounds could constitute an alternative as therapeutic agents against cancer. In this regard, Gajendran, Durai, Varier, and Chinnasamy [22] reported that Rinoxia B (4 and $10 \mu \mathrm{M})$, a phytosterol isolated from leaf extract of Datura inoxia, induces apoptosis via upregulation Bax/Bcl-2 ratio and inhibits cell proliferation through downregulation of cell cycle regulatory proteins (Cyclidin D1 and B1) and $\mathrm{G}_{2} / \mathrm{M}$ arrest in HCT 15 human colon adenocarcinoma cell line. Meanwhile Alvarez-Sala et al. [243] indicated that phytosterols ( $\beta$-sitosterol, sitostanol, campesterol, campestanol, and stigmasterol) from tall oil (13 $\mu \mathrm{M})$ exert an antiproliferative effect in the breast (MCF-7), colon (HCT116), and cervical (HeLa) cancer cell lines, through the increase of sub-G1 cell population (apoptotic cells).

Although there are many studies on the anticancer effects of terpenes and phytosterols, clinical studies in humans are needed to confirm the findings reported both in vitro as in mice models. Additionally, based on revised studies, it is highly recommended to explore and evaluate the anticancer effect of phytosterols from fruit waste, such as apple, papaya, and guava seed oils containing significant amounts of stigamasterol and $\beta$-sitosterol [35]. 


\subsection{Anti-Bacterial}

Plants contain numerous bioactive compounds that provide diverse properties and beneficial effects for human health $[244,245]$. The literature describes a wide variety of bioactive compounds from fruit and vegetables, including phenolic compounds, phytosterols, saponins, aldehydes, and terpenoids, which are gaining scientific interest and exhibit antioxidant, anti-inflammatory, immunomodulatory, antiviral, and antibacterial activities [246-251]. Antibacterial activity of phenolic compounds such as myricetin, bacalein, pyrogallic acid, resveratrol, epigallocatechin, punicalagin, tannic acid, castalagin, prodelphinidin, geraniin, procyanidins, and theaflavin have been reported. These compounds present an inhibitory effect on the growth of bacteria species, including pathogens as Aeromonas hydrophila, Bacillus brevis, Bacillus cereus, Bacillus megaterium, Bacillus subtilis, Enterobacter aerogenes, Enterobacter sakazakii, Enterococcus faecalis, Escherichia coli, Klebsiella pneumoniae, Listeria monocytogenes, Mycobacterium smegmatis, Proteus vulgaris, Pseudomonas aeruginosa, Staphylococcus aureus, Salmonella typhimurium, and Vibrio cholerae, among others [252-254].

The antibacterial activity of phenolic compounds is mainly associated with damage to the membrane structure $[255,256]$. The action over Gram-positive and Gram-negative bacteria varies due to bacteria cell membrane structure [257]; some phenolic compounds have lower affinity to negatively charged lipopolysaccharides, thus reducing the affinity of these compounds to Gram-negative bacteria [258]. For instance, Bouarab-Chibane et al. [259] studied the effect of 35 polyphenols compounds in six foodborne strains (B. subtilis, L. monocytogenes, S. aureus, E. coli, P. aeruginosa, and Salmonella spp.); obtained results demonstrated that resveratrol and pinosylvin presented antibacterial activity against the Gram-positive bacteria. Caffeic acid 1,1-dimethylallyl ester showed antibacterial activity against Gram-negative bacteria. The mechanisms of action of phenolic compounds on bacterial cell membranes have been attributed to the disruption of the lipid bilayer, increasing permeability in the outer and inner membrane, altering the ion transport processes, producing lipid membrane aggregation, and affecting the membrane fluidity [255,260-262].

Epigallocatechin-3-gallate (EGCG) is a biological active polyphenol compound, commonly found in green tea and grape seeds, that presents a wide spectrum of activity against Gram-positive and Gram-negative bacteria $[257,263]$. The inhibitory mechanisms of EGCG against bacteria have been reported by several pathogens such as B. subtilis, Campylobacter jejuni, E. coli, P. aeruginosa, Stenotrophomonas maltophilia, S. aureus, S. typhimurium, Helicobacter pylori, and V. cholerae [263-271]. EGCG is capable of inhibiting the adherence to epithelial cells and reducing the hemolysis capability of Fusobacterium nucleatum [272], enhancing the integrity of the epithelial barrier of the host cell by inducing overexpression of tight junctions proteins (ZO-1 and occludin), thus avoiding the disruption of the epithelial barrier caused by Porphyromonas gingivalis [273]. Phenolic compounds obtained from grape extracts have been reported to present an inhibitory effect against bacteria and their toxins [254,274,275]. Reddy et al. [276] reported that phenolic compounds from grape extracts could disrupt the action of $V$. cholerae toxin (CT). In assays with $\mathrm{CHO}$ cells, the polyphenol extracts blocked the CT binding to the cell surface, inhibited the toxin translocation to the cytosol, and disrupted the catalytic activity of CT subunits of the polyphenols extract were evident even after toxin internalization into the host cell. Furthermore, Cherubin, Garcia, Curtis, Britt, Craft, Burress, Berndt, Reddy, Guyette, Zheng, Huo, Quiñones, Briggs, and Teter [265] found that the combination of grape extract compounds as EGCG and procyanidin B2 (PB2) prevent CT binding to the cell surface in a dose-dependent manner $(1.7 \mu \mathrm{g} / \mathrm{mL})$; those authors suggest that EGCG and PB2 inhibited the CT activity against cultured cells by disrupting the interactions with the surface receptor (GM1) of the host plasma membrane.

The polyphenols are also involucrate in the modulation of the metabolic system and genes inhibition; the antibacterial activity of tannins is associated with producing morphological and structural alterations in the cell wall of $S$. aureus via suppression of genes involved in RNA and protein synthesis [256]; procyanidins are capable of altering the metabolic energy systems, resulting in a slowdown of metabolism and bacterial growth inhibition [277]. Biancalani et al. [278] reported the 
effect of nine phenolic compounds (catechin, epicathechin, epigallocatechin gallate, oleuropein, hydroxytyrosol, luteolin-7-O-glucoside, caffeic acid, chlorogenic acid, cynarine) obtained from Olea europaea, Cynara scolymus, and Vitis vinifera, most of them affect the assembly of the Type Three Secretion System (TTSS) translocation pilus via inactivation of the gene $h r p A$; nevertheless, authors indicate that the effect does not present a diminution of the growth of Pseudomonas savastanoi.

Quorum sensing (QS) is a molecular communication system of bacteria. Genes implicated in QS control various phenotypes, including bioluminescence, biofilm formation, drug resistance, virulence factors expression, and motility [279]. Recent studies have demonstrated that phenolic compounds are implicated in the process of regulating the bacteria growth by targeting the QS system [280,281]. Mostafa et al. [282] detected 38 metabolites obtained from Salix tetrasperma extract that exhibit proteolytic, hemolytic, and motility inhibition in assays with P. aeruginosa. These authors indicate that epicatechin, (epi)catechin-(epi)catechin, p-hydroxy benzoyl galloyl glucose, p-hydroxy benzoyl protocatechuic acid glucose, and caffeoylmalic acid affect QS controlling systems (Lasl/LasR, rhll/rhlR, and PQS/MvfR) of the pathogen. Similar results were obtained in vitro treatment. Yin et al. [283] indicate that tea extract affects proteolytic activity, swarming motility, and biofilm formation, resulting in the reduction of pathogenicity of the strain. Carraro et al. [191] reported that polyphenolic compounds are capable of inhibiting key genes ( $b h s A, c s g C, r c s A, b s s S, b s s R, y d a M, y d d V, y h j H)$ involved in the biofilm formation of E. coli [284]. Similar results have been reported for other phenolic compounds, such as pyrogallol and methyl gallate in different bacteria, including Vibrio harveyi, Ralstonia solanacearum, and emphP. aeruginosa [285-287].

The antibacterial activity of phenolic compounds can also impact the composition and function of the human gut microbiota. These compounds can increase beneficial bacteria species (Bifidobacterium spp) or inhibit pathogenic bacteria such as Clostridium perfringens, C. difficile, and Bacteroides spp. [288-290]. Therefore, the effect of the phenolic compounds from plant waste on human gut microbiota is an important area of scientific interest that deserves to be researched in detail.

\section{Conclusions and Future Perspectives}

The use of non-conventional extraction technologies or green technologies to obtain antioxidant molecules such as terpenes, phenolic compounds, phytosterols, and bioactive peptides from plant waste has increased in recent years in order to exploit and give added value to this type of waste, reduce environmental impact, obtain high quality extracts, safe products, reduce energy and solvent consumption, and increase the yield of the final product. Likewise, the number of studies focused on optimizing the conditions of the recovery process of this type of molecule has augmented, due to the nature of the plant material and the structural chemical differences (hydrophilicity and lipophilicity) presented by the antioxidant molecules discussed here, which have been widely studied due to their potential to prevent or treat cardiovascular diseases and others related to metabolic syndrome. However, although there is a wide variety of studies on the potential benefit of antioxidant molecules on human health, clinical studies are needed to confirm the findings reported both in vitro in animal models.

Extraction of antioxidant molecules by SFE represents a viable option for its potential use at an industrial scale. Antioxidants obtained by SFE maintain their chemical structure and functional properties. Furthermore, the solvent $\mathrm{CO}_{2}$ used in SFE is safe and available. Additionally, SFE is already being used in industrial processes, such as coffee decaffeination, which reveals its scalable potential.

Author Contributions: Writing-original draft preparation: C.E.L.-V. and N.L.-L.; investigation: C.E.L.-V., N.L.-L., E.P.G.-G., J.A.S.-L., I.O.-R., E.M.-M., J.P.A.-G., A.G., A.B.-H., and A.A.-S. Writing-review and editing: C.H. All authors have read and agreed to the published version of the manuscript.

Funding: This research received no external funding.

Acknowledgments: This manuscript is part of the activities of the Cátedras-CONACYT Project \#729: Applied biotechnologies for the development of functional foods for aquaculture (Biotecnologías aplicadas para el desarrollo de alimentos funcionales para acuacultura). 
Conflicts of Interest: The authors declare no conflict of interest.

\section{References}

1. FAO. Strategic Work of FAO for Sustainable Food and Agriculture. Available online: http://www.fao.org/3/ai6488e.pdf (accessed on 12 November 2020).

2. FAO. The State of Food and Agriculture Moving Forward on Food Loss and Waste Reduction. Available online: http://www.fao.org/3/ca6030en/ca6030en.pdf (accessed on 12 November 2020).

3. Esparza, I.; Jiménez-Moreno, N.; Bimbela, F.; Ancín-Azpilicueta, C.; Gandía, L.M. Fruit and vegetable waste management: Conventional and emerging approaches. Australas. J. Environ. Manag. 2020, 265, 110510. [CrossRef] [PubMed]

4. FAO. Utilization of Fruit and Vegetable Wastes as Livestock Feed and as Substrates for Generation of Other Value Added Products. Available online: http://www.fao.org/3/i3273e/i3273e.pdf (accessed on 12 November 2020).

5. Belc, N.; Mustatea, G.; Apostol, L.; Iorga, S.; Vlăduţ, V.-N.; Mosoiu, C. Cereal supply chain waste in the context of circular economy. In Proceedings of the 8th International Conference on Thermal Equipment, Renewable Energy and Rural Development (TE-RE-RD 2019), Târgovişte, Romania, 20 August 2019; p. 8.

6. Leyva-López, N.; Lizárraga-Velázquez, C.E.; Hernández, C.; Sánchez-Gutiérrez, E.Y. Exploitation of agro-industrial waste as potential source of bioactive compounds for aquaculture. Foods 2020, 9, 843. [CrossRef]

7. Balasundram, N.; Sundram, K.; Samman, S. Phenolic compounds in plants and agri-industrial by-products: Antioxidant activity, occurrence, and potential uses. Food Chem. 2006, 99, 191-203. [CrossRef]

8. González-López, Á.M.; Quiñones-Aguilar, E.E.; Rincón-Enríquez, G. Actividad biológica de los terpenos en el área agroalimentaria. In Los Compuestos Bioactivos y Tecnologías de Extracción; Espinosa Andrews, H., García Marquez, E., Gastelum Martínez, E., Eds.; Centro de Investigación y Asistencia en Tecnología y Diseño del Estado de Jalisco, A. C. (CIATEJ): Guadalajara, Mexico, 2016.

9. Görgüç, A.; Özer, P.; Yılmaz, F.M. Microwave-assisted enzymatic extraction of plant protein with antioxidant compounds from the food waste sesame bran: Comparative optimization study and identification of metabolomics using LC/Q-TOF/MS. J. Food Process. Preserv. 2020, 44, e14304. [CrossRef]

10. Yoshida, Y.; Niki, E. Antioxidant effects of phytosterol and its components. J. Nutr. Sci. Vitaminol. 2003, 49, 277-280. [CrossRef] [PubMed]

11. Alongi, M.; Melchior, S.; Anese, M. Reducing the glycemic index of short dough biscuits by using apple pomace as a functional ingredient. LWT Food Sci. Technol. 2019, 100, 300-305. [CrossRef]

12. Dang, Y.; Zhou, T.; Hao, L.; Cao, J.; Sun, Y.; Pan, D. In vitro and in vivo studies on the angiotensin-converting enzyme inhibitory activity peptides isolated from broccoli protein hydrolysate. J. Agric. Food Chem. 2019, 67, 6757-6764. [CrossRef]

13. Guesmi, F.; Prasad, S.; Tyagi, A.K.; Landoulsi, A. Antinflammatory and anticancer effects of terpenes from oily fractions of Teucruim alopecurus, blocker of $\mathrm{I} \kappa \mathrm{B} \alpha$ kinase, through downregulation of NF- $\mathrm{k}$ activation, potentiation of apoptosis and suppression of NF-kB-regulated gene expression. Biomed. Pharmacother. 2017, 95, 1876-1885. [CrossRef]

14. Gautam, M.; Thapa, R.K.; Gupta, B.; Soe, Z.C.; Ou, W.; Poudel, K.; Jin, S.G.; Choi, H.-G.; Yong, C.S.; Kim, J.O. Phytosterol-loaded CD44 receptor-targeted PEGylated nano-hybrid phyto-liposomes for synergistic chemotherapy. Expert Opin. Drug Del. 2020, 17, 423-434. [CrossRef]

15. Santos, I.B.; de Bem, G.F.; Cordeiro, V.S.C.; da Costa, C.A.; de Carvalho, L.; da Rocha, A.P.M.; da Costa, G.F.; Ognibene, D.T.; de Moura, R.S. Supplementation with Vitis vinifera L. skin extract improves insulin resistance and prevents hepatic lipid accumulation and steatosis in high-fat diet-fed mice. Nutr. Res. 2017, 43, 69-81. [CrossRef]

16. Fierascu, R.C.; Fierascu, I.; Avramescu, S.M.; Sieniawska, E. Recovery of natural antioxidants from agro-industrial side streams through advanced extraction techniques. Molecules 2019, 24, 4212. [CrossRef]

17. Kumar, K.; Yadav, A.N.; Kumar, V.; Vyas, P.; Dhaliwal, H.S. Food waste: A potential bioresource for extraction of nutraceuticals and bioactive compounds. Bioresour. Bioprocess. 2017, 4, 18. [CrossRef] 
18. Saini, A.; Panesar, P.S.; Bera, M.B. Valorization of fruits and vegetables waste through green extraction of bioactive compounds and their nanoemulsions-based delivery system. Bioresour. Bioprocess. 2019, 6, 26. [CrossRef]

19. Panzella, L.; Moccia, F.; Nasti, R.; Marzorati, S.; Verotta, L.; Napolitano, A. Bioactive phenolic compounds from agri-food wastes: An update on green and sustainable extraction methodologies. Front. Nutr. 2020, 7, 60. [CrossRef] [PubMed]

20. Colantuono, A.; Ferracane, R.; Vitaglione, P. In vitro bioaccessibility and functional properties of polyphenols from pomegranate peels and pomegranate peels-enriched cookies. Food Funct. 2016, 7, 4247-4258. [CrossRef] [PubMed]

21. Hou, J.; Zhang, Y.; Zhu, Y.; Zhou, B.; Ren, C.; Liang, S.; Guo, Y. $\alpha$-Pinene induces apoptotic cell death via caspase activation in human ovarian cancer cells. Med. Sci. Monit. 2019, 25, 6631-6638. [CrossRef]

22. Gajendran, B.; Durai, P.; Varier, K.M.; Chinnasamy, A. A novel phytosterol isolated from Datura inoxia, RinoxiaB is a potential cure colon cancer agent by targeting BAX/Bcl2 pathway. Bioorg. Med. Chem. 2020, 28, 115242. [CrossRef]

23. Urquiaga, I.; Troncoso, D.; Mackenna, M.J.; Urzua, C.; Perez, D.; Dicenta, S.; de la Cerda, P.M.; Amigo, L.; Carreno, J.C.; Echeverria, G.; et al. The consumption of beef burgers prepared with wine grape pomace flour improves fasting glucose, plasma antioxidant levels, and oxidative damage markers in humans: A controlled trial. Nutrients 2018, 10, 1388. [CrossRef]

24. Zhang, Y.-J.; Gan, R.-Y.; Li, S.; Zhou, Y.; Li, A.-N.; Xu, D.-P.; Li, H.-B. Antioxidant phytochemicals for the prevention and treatment of chronic diseases. Molecules 2015, 20, 21138-21156. [CrossRef]

25. Fierascu, R.C.; Sieniawska, E.; Ortan, A.; Fierascu, I.; Xiao, J. Fruits by-products-A source of valuable active principles. A short review. Front. Bioeng. Biotechnol. 2020, 8, 319. [CrossRef]

26. González-García, E.; Puchalska, P.; Marina, M.L.; García, M.C. Fractionation and identification of antioxidant and angiotensin-converting enzyme-inhibitory peptides obtained from plum (Prunus domestica L.) stones. J. Funct. Food. 2015, 19, 376-384. [CrossRef]

27. He, R.; Yang, Y.-J.; Wang, Z.; Xing, C.-r.; Yuan, J.; Wang, L.-F.; Udenigwe, C.; Ju, X.-R. Rapeseed protein-derived peptides, LY, RALP, and GHS, modulates key enzymes and intermediate products of renin-angiotensin system pathway in spontaneously hypertensive rat. NPJ Sci. Food 2019, 3, 1-6. [CrossRef] [PubMed]

28. Liu, J.-J.; Gasmalla, M.A.A.; Li, P.; Yang, R. Enzyme-assisted extraction processing from oilseeds: Principle, processing and application. Innov. Food Sci. Emerg. Technol. 2016, 35, 184-193. [CrossRef]

29. Moayedi, A.; Mora, L.; Aristoy, M.C.; Safari, M.; Hashemi, M.; Toldrá, F. Peptidomic analysis of antioxidant and ACE-inhibitory peptides obtained from tomato waste proteins fermented using Bacillus Subtilis. Food Chem. 2018, 250, 180-187. [CrossRef] [PubMed]

30. Vaásquez-Villanueva, R.; Orellana, J.M.A.; Marina, M.L.; García, M.C. Isolation and characterization of angiotensin converting enzyme inhibitory peptides from peach seed hydrolysates: In vivo assessment of antihypertensive activity. J. Agric. Food Chem. 2019, 67, 10313-10320. [CrossRef]

31. Wang, X.; Chen, H.; Fu, X.; Li, S.; Wei, J. A novel antioxidant and ACE inhibitory peptide from rice bran protein: Biochemical characterization and molecular docking study. LWT Food Sci. Technol. 2017, 75, 93-99. [CrossRef]

32. Zheng, Y.; Li, Y.; Li, G. ACE-inhibitory and antioxidant peptides from coconut cake albumin hydrolysates: Purification, identification and synthesis. RSC Adv. 2019, 9, 5925-5936. [CrossRef]

33. Zhou, Q.F.; Zhou, J.X.; Liu, X.J.; Zhang, Y.B.; Cai, S.B. Digestive enzyme inhibition of different phenolic fractions and main phenolic compound of ultra-high-pressure-treated palm fruits: Interaction and molecular docking analyses. J. Food Qual. 2020, 2020, 8811597. [CrossRef]

34. Teixeira, S.D.; Fiorio, J.L.; Galvan, D.; Sefstrom, C.; Cogo, P.M.; Sales Junior, V.; Rodrigues, M.B.; Hendges, A.P.P.K.; Maia, B.H.L.d.N.S. Investigation on chemical composition and optimization of essential oil obtainment from waste Pinus taeda L. using hydrodistillation. Braz. Arch. Biol. Technol. 2016, 59, e16150043. [CrossRef]

35. da Silva, A.C.; Jorge, N. Bioactive compounds of oils extracted from fruits seeds obtained from agroindustrial waste. Eur. J. Lipid Sci. Technol. 2017, 119, 1600024. [CrossRef]

36. Jiang, Y.; Wang, T. Phytosterols in cereal by-products. J. Am. Oil Chem. Soc. 2005, 82, 439-444. [CrossRef] 
37. Uddin, M.; Ferdosh, S.; Haque Akanda, M.J.; Ghafoor, K.; Rukshana, A.; Ali, M.E.; Kamaruzzaman, B.; Fauzi, M.; Shaarani, S.; Islam Sarker, M.Z. Techniques for the extraction of phytosterols and their benefits in human health: A review. Sep. Sci. Technol. 2018, 53, 2206-2223. [CrossRef]

38. Gençdağ, E.; Görgüç, A.; Yılmaz, F.M. Recent advances in the recovery techniques of plant-based proteins from agro-industrial by-products. Food Rev. Int. 2020, 1-22. [CrossRef]

39. Singh, B.; Sharma, R.A. Plant terpenes: Defense responses, phylogenetic analysis, regulation and clinical applications. 3 Biotech 2015, 5, 129-151. [CrossRef] [PubMed]

40. Matus, M.F.; Jorquera-Román, M.; Zúñiga-Hernández, J. Anti-proliferative effect of terpenes on human prostate cancer cells: Natural sources and their potential role as chemopreventive agents. Rev. Chil. Nutr. 2017, 44, 371-382. [CrossRef]

41. Ashour, M.; Wink, M.; Gershenzon, J. Biochemistry of terpenoids: Monoterpenes, sesquiterpenes and diterpenes. In Annual Plant Reviews Online, 2nd ed.; Wink, M., Ed.; John Wiley and Sons: Hoboken, NJ, USA, 2010; Volume 40, pp. 258-303.

42. National Center for Biotechnology Information. PubChem Compound Summary for CID 5281520, Humulene. Available online: https:/pubchem.ncbi.nlm.nih.gov/compound/Humulene (accessed on 19 November 2020).

43. National Center for Biotechnology Information. PubChem Compound Summary for CID 6654, Alpha-Pinene. Available online: https://pubchem.ncbi.nlm.nih.gov/compound/alpha-Pinene (accessed on 20 November 2020).

44. National Center for Biotechnology Information. PubChem Compound Summary for CID 16061204, Lutein. Available online: https://pubchem.ncbi.nlm.nih.gov/compound/Lutein-G (accessed on 19 November 2020).

45. National Center for Biotechnology Information. PubChem Compound Summary for CID 446925, Lycopene. Available online: https:/pubchem.ncbi.nlm.nih.gov/compound/Lycopene (accessed on 19 November 2020).

46. National Center for Biotechnology Information. PubChem Compound Summary for CID 5280863, Kaempferol. Available online: https://pubchem.ncbi.nlm.nih.gov/compound/Kaempferol (accessed on 9 September 2020).

47. National Center for Biotechnology Information. PubChem Compound Summary for CID 370, Gallic Acid. Available online: https://pubchem.ncbi.nlm.nih.gov/compound/Gallic-acid (accessed on 19 November 2020).

48. National Center for Biotechnology Information. PubChem Compound Summary for CID 73160, Catechin. Available online: https://pubchem.ncbi.nlm.nih.gov/compound/Catechin (accessed on 20 November 2020).

49. National Center for Biotechnology Information. PubChem Compound Summary for CID 72276, Epicatechin. Available online: https://pubchem.ncbi.nlm.nih.gov/compound/Epicatechin (accessed on 19 November 2020).

50. National Center for Biotechnology Information. PubChem Compound Summary for CID 173183, Campesterol. Available online: https://pubchem.ncbi.nlm.nih.gov/compound/Campesterol (accessed on 19 November 2020).

51. National Center for Biotechnology Information. PubChem Compound Summary for CID 222284, beta-Sitosterol. Available online: https://pubchem.ncbi.nlm.nih.gov/compound/beta-Sitosterol (accessed on 19 November 2020).

52. National Center for Biotechnology Information. PubChem Compound Summary for CID 5280794, Stigmasterol. Available online: https://pubchem.ncbi.nlm.nih.gov/compound/Stigmasterol (accessed on 19 November 2020).

53. Schrader, J.; Bohlmann, J. Biotechnology of Isoprenoids; Springer: Cham, Switzerland, 2015; Volume 149.

54. Chudzik, M.; Korzonek-Szlacheta, I.; Król, W. Triterpenes as potentially cytotoxic compounds. Molecules 2015, 20, 1610-1625. [CrossRef] [PubMed]

55. Leyva-López, N.; Gutiérrez-Grijalva, E.P.; Vazquez-Olivo, G.; Contreras-Angulo, L.A.; Emus-Medina, A.; Heredia, J.B. Terpenes in oregano: Constituents, extraction, analysis and biological properties. In Terpenes: Biosynthesis, Applications and Research; Bjarke, A., Ed.; Nova Science Publishers, Inc.: New York, NY, USA, 2018; pp. 1-64.

56. Barreto, R.S.; Quintans, J.S.; Amarante, R.K.; Nascimento, T.S.; Amarante, R.S.; Barreto, A.S.; Pereira, E.W.; Duarte, M.C.; Coutinho, H.D.; Menezes, I.R. Evidence for the involvement of TNF- $\alpha$ and IL-1 $\beta$ in the antinociceptive and anti-inflammatory activity of Stachys lavandulifolia Vahl. (Lamiaceae) essential oil and (-)- $\alpha$-bisabolol, its main compound, in mice. J. Ethnopharmacol. 2016, 191, 9-18. [CrossRef]

57. Sarmento-Neto, J.F.; Do Nascimento, L.G.; Felipe, C.F.B.; De Sousa, D.P. Analgesic potential of essential oils. Molecules 2016, 21, 20. [CrossRef] 
58. Gouveia, D.N.; Pina, L.T.; Rabelo, T.K.; da Rocha Santos, W.B.; Quintans, J.S.S.; Guimaraes, A.G. Monoterpenes as perspective to chronic pain management: A systematic review. Curr. Drug Targets 2018, 19, 960-972. [CrossRef] 
59. Leyva-López, N.; Nair, V.; Bang, W.Y.; Cisneros-Zevallos, L.; Heredia, J.B. Protective role of terpenes and polyphenols from three species of Oregano (Lippia graveolens, Lippia palmeri and Hedeoma patens) on the suppression of lipopolysaccharide-induced inflammation in RAW 264.7 macrophage cells. J. Ethnopharmacol. 2016, 187, 302-312. [CrossRef]

60. Dutra, R.C.; da Silva, K.A.B.S.; Bento, A.F.; Marcon, R.; Paszcuk, A.F.; Meotti, F.C.; Pianowski, L.F.; Calixto, J.B. Euphol, a tetracyclic triterpene produces antinociceptive effects in inflammatory and neuropathic pain: The involvement of cannabinoid system. Neuropharmacology 2012, 63, 593-605. [CrossRef] [PubMed]

61. Brito, R.G.; Araujo, A.A.; Quintans, J.S.; Sluka, K.A.; Quintans-Junior, L.J. Enhanced analgesic activity by cyclodextrins-a systematic review and meta-analysis. Expert Opin. Drug Del. 2015, 12, 1677-1688. [CrossRef] [PubMed]

62. Salinas-Sánchez, D.O.; Zamilpa, A.; Pérez, S.; Herrera-Ruiz, M.; Tortoriello, J.; González-Cortazar, M.; Jiménez-Ferrer, E. Effect of hautriwaic acid isolated from Dodonaea viscosa in a model of kaolin/carrageenan-induced monoarthritis. Planta Med. 2015, 81, 1240-1247. [CrossRef] [PubMed]

63. Wen, T.; Xu, W.; Liang, L.; Li, J.; Ding, X.; Chen, X.; Hu, J.; Lv, A.; Li, X. Clinical efficacy of andrographolide sulfonate in the treatment of severe hand, foot, and mouth disease (HFMD) is dependent upon inhibition of neutrophil activation. Phytother. Res. 2015, 29, 1161-1167. [CrossRef] [PubMed]

64. Nazzaro, F.; Fratianni, F.; Coppola, R.; Feo, V.D. Essential oils and antifungal activity. Pharmaceuticals 2017, 10, 86. [CrossRef]

65. Hansen, J.S.; Nørgaard, A.W.; Koponen, I.K.; Sørli, J.B.; Paidi, M.D.; Hansen, S.W.; Clausen, P.A.; Nielsen, G.D.; Wolkoff, P.; Larsen, S.T. Limonene and its ozone-initiated reaction products attenuate allergic lung inflammation in mice. J. Immunotoxicol. 2016, 13, 793-803. [CrossRef] [PubMed]

66. Valdivieso-Ugarte, M.; Gomez-Llorente, C.; Plaza-Díaz, J.; Gil, Á. Antimicrobial, antioxidant, and immunomodulatory properties of essential oils: A systematic review. Nutrients 2019, 11, 2786. [CrossRef]

67. Pandey, A.K.; Kumar, P.; Singh, P.; Tripathi, N.N.; Bajpai, V.K. Essential oils: Sources of antimicrobials and food preservatives. Front. Microbiol. 2017, 7, 2161. [CrossRef]

68. Meng, X.; Li, D.; Zhou, D.; Wang, D.; Liu, Q.; Fan, S. Chemical composition, antibacterial activity and related mechanism of the essential oil from the leaves of Juniperus rigida Sieb. et Zucc against Klebsiella pneumoniae. J. Ethnopharmacol. 2016, 194, 698-705. [CrossRef]

69. Montironi, I.D.; Cariddi, L.N.; Reinoso, E.B. Evaluation of the antimicrobial efficacy of Minthostachys verticillata essential oil and limonene against Streptococcus uberis strains isolated from bovine mastitis. Rev. Arg. Microbiol. 2016, 48, 210-216. [CrossRef]

70. Yang, C.; Zhang, L.; Cao, G.; Feng, J.; Yue, M.; Xu, Y.; Dai, B.; Han, Q.; Guo, X. Effects of dietary supplementation with essential oils and organic acids on the growth performance, immune system, fecal volatile fatty acids, and microflora community in weaned piglets. J. Anim. Sci. 2020, 97, 133-143. [CrossRef] [PubMed]

71. Saini, R.K.; Nile, S.H.; Park, S.W. Carotenoids from fruits and vegetables: Chemistry, analysis, occurrence, bioavailability and biological activities. Food Res. Int. 2015, 76, 735-750. [CrossRef] [PubMed]

72. Britton, G. Carotenoid research: History and new perspectives for chemistry in biological systems. BBA-Mol. Cell. Biol. L. 2020, 1865, 158699. [CrossRef] [PubMed]

73. Tan, K.; Zhang, H.; Lim, L.-S.; Ma, H.; Li, S.; Zheng, H. Roles of carotenoids in invertebrate immunology. Front. Immunol. 2020, 10. [CrossRef]

74. Lizárraga-Velázquez, C.E.; Hernández, C.; González-Aguilar, G.A.; Heredia, J.B. Effect of hydrophilic and lipophilic antioxidants from mango peel (Mangifera indica L. cv. Ataulfo) on lipid peroxidation in fish oil. CyTA-J. Food 2018, 16, 1095-1101. [CrossRef]

75. Sharma, A.; Bajpai, V.K.; Shukla, S. Sesquiterpenes and cytotoxicity. In Natural products: Phytochemistry, Botany and Metabolism of Alkaloids, Phenolics and Terpenes; Ramawat, K.G., Mérillon, J.-M., Eds.; Springer: Berlin/Heidelberg, Germany, 2013; pp. 3515-3550.

76. Langhasova, L.; Hanusova, V.; Rezek, J.; Stohanslova, B.; Ambroz, M.; Kralova, V.; Vanek, T.; Lou, J.D.; Yun, Z.L.; Yang, J.; et al. Essential oil from Myrica rubra leaves inhibits cancer cell proliferation and induces apoptosis in several human intestinal lines. Ind. Crop. Prod. 2014, 59, 20-26. [CrossRef]

77. Vermerris, W.; Nicholson, R. Families of phenolic compounds and means of classification. In Phenolic Compound Biochemistry; Springer: Dordrecht, The Netherlands, 2006; pp. 1-34. 
78. Gutiérrez-Grijalva, E.P.; Ambriz-Pére, D.L.; Leyva-López, N.; Castillo-López, R.I.; Heredia, J.B. Review: Dietary phenolic compounds, health benefits and bioaccessibility. Archivos Latinoamericanos de Nutrición 2016, $66,87-100$.

79. Tungmunnithum, D.; Thongboonyou, A.; Pholboon, A.; Yangsabai, A. Flavonoids and other phenolic compounds from medicinal plants for pharmaceutical and medical aspects: An overview. Medicines 2018, 5, 93. [CrossRef]

80. Khan, H.; Reale, M.; Ullah, H.; Sureda, A.; Tejada, S.; Wang, Y.; Zhang, Z.-J.; Xiao, J. Anti-cancer effects of polyphenols via targeting p53 signaling pathway: Updates and future directions. Biotechnol. Adv. 2020, 38, 107385. [CrossRef]

81. Gylling, H.; Simonen, P. Phytosterols, phytostanols, and lipoprotein metabolism. Nutrients 2015, 7, 7965-7977. [CrossRef]

82. Shahzad, N.; Khan, W.; Shadab, M.; Ali, A.; Saluja, S.S.; Sharma, S.; Al-Allaf, F.A.; Abduljaleel, Z.; Ibrahim, I.A.A.; Abdel-Wahab, A.F. Phytosterols as a natural anticancer agent: Current status and future perspective. Biomed. Pharmacother. 2017, 88, 786-794. [CrossRef] [PubMed]

83. Miras-Moreno, B.; Sabater-Jara, A.B.; Pedreño, M.; Almagro, L. Bioactivity of phytosterols and their production in plant in vitro cultures. J. Agric. Food Chem. 2016, 64, 7049-7058. [CrossRef] [PubMed]

84. Zaloga, G.P. Phytosterols, lipid administration, and liver disease during parenteral nutrition. JPEN J. Parenter. Enteral. Nutr. 2015, 39, 39S-60S. [CrossRef] [PubMed]

85. Comunian, T.A.; Favaro-Trindade, C.S. Microencapsulation using biopolymers as an alternative to produce food enhanced with phytosterols and omega-3 fatty acids: A review. Food Hydrocolloid. 2016, 61, 442-457. [CrossRef]

86. Lin, Y.; Knol, D.; Trautwein, E.A. Phytosterol oxidation products (POP) in foods with added phytosterols and estimation of their daily intake: A literature review. Eur. J. Lipid Sci. Technol. 2016, 118, 1423-1438. [CrossRef]

87. Ogbe, R.J.; Ochalefu, D.O.; Mafulul, S.G.; Olaniru, O.B. A review on dietary phytosterols: Their occurrence, metabolism and health benefits. Asian J. Plant Sci. Res. 2015, 5, 10-21.

88. Ramprasath, V.R.; Awad, A.B. Role of phytosterols in cancer prevention and treatment. J. AOAC Int. 2015, 98, 735-738. [CrossRef]

89. Plat, J.; Hendrikx, T.; Bieghs, V.; Jeurissen, M.L.; Walenbergh, S.M.; van Gorp, P.J.; De Smet, E.; Konings, M.; Vreugdenhil, A.C.; Guichot, Y.D. Protective role of plant sterol and stanol esters in liver inflammation: Insights from mice and humans. PLoS ONE 2014, 9, e110758. [CrossRef]

90. Rico, X.; Gullón, B.; Alonso, J.L.; Yáñez, R. Recovery of high value-added compounds from pineapple, melon, watermelon and pumpkin processing by-products: An overview. Food Res. Int. 2020, 132, 109086. [CrossRef]

91. Ben-Othman, S.; Jõudu, I.; Bhat, R. Bioactives from agri-food wastes: Present insights and future challenges. Molecules 2020, 25, 510. [CrossRef]

92. Banerjee, J.; Singh, R.; Vijayaraghavan, R.; MacFarlane, D.; Patti, A.F.; Arora, A. Bioactives from fruit processing wastes: Green approaches to valuable chemicals. Food Chem. 2017, 225, 10-22. [CrossRef] [PubMed]

93. Meneguetti, B.T.; Machado, L.D.S.; Oshiro, K.G.N.; Nogueira, M.L.; Carvalho, C.M.E.; Franco, O.L. Antimicrobial peptides from fruits and their potential use as biotechnological tools-A review and outlook. Front. Microbiol. 2017, 7, 2136. [CrossRef] [PubMed]

94. da Silva Dantas, C.C.; de Souza, E.L.; Cardoso, J.D.; de Lima, L.A.; de Sousa Oliveira, K.; Migliolo, L.; Dias, S.C.; Franco, O.L.; Magnani, M. Identification of a napin-like peptide from Eugenia malaccensis L. Seeds with inhibitory activity toward Staphylococcus aureus and Salmonella enteritidis. Protein J. 2014, 33, 549-556. [CrossRef] [PubMed]

95. Zhang, Q.-W.; Lin, L.-G.; Ye, W.-C. Techniques for extraction and isolation of natural products: A comprehensive review. Chin. Med. 2018, 13, 20. [CrossRef]

96. Chemat, F.; Rombaut, N.; Sicaire, A.-G.; Meullemiestre, A.; Fabiano-Tixier, A.-S.; Abert-Vian, M. Ultrasound assisted extraction of food and natural products. Mechanisms, techniques, combinations, protocols and applications. A review. Ultrason. Sonochem. 2017, 34, 540-560. [CrossRef]

97. Ludwiczuk, A.; Skalicka-Woźniak, K.; Georgiev, M. Chapter 11-Terpenoids A2-Badal, Simone. In Pharmacognosy; Academic Press: Boston, MA, USA, 2017; pp. 233-266.

98. Yadav, N.; Yadav, R.; Goyal, A. Chemistry of terpenoids. Int. J. Pharm. Sci. Rev. Res. 2014, 27, $272-278$. 
99. Uysal, S.; Cvetanović, A.; Zengin, G.; Zeković, Z.; Mahomoodally, M.F.; Bera, O. Optimization of maceration conditions for improving the extraction of phenolic compounds and antioxidant effects of Momordica charantia L. leaves through response surface methodology (RSM) and artificial neural networks (ANNs). Anal. Lett. 2019, 52, 2150-2163. [CrossRef]

100. Soquetta, M.B.; Terra, L.D.M.; Bastos, C.P. Green technologies for the extraction of bioactive compounds in fruits and vegetables. CyTA-J. Food 2018, 16, 400-412. [CrossRef]

101. Gupta, A.; Naraniwal, M.; Kothari, V. Modern extraction methods for preparation of bioactive plant extracts. Int. J. Appl. Nat. Sci. 2012, 1, 8-26.

102. Gololo, S.S.; Shai, L.J.; Sethoga, L.; Agyei, N.; Bassey, K.E.; Mogale, M.A. Isolation of a mixture of phytosterol compounds from the n-Hexane extract of Jatropha lagarinthoides (Sond) collected from Zebediela sub-region in Limpopo province, South Africa. J. Chem. Pharm. Sci. 2016, 9, 3084-3087.

103. Azmir, J.; Zaidul, I.S.M.; Rahman, M.M.; Sharif, K.M.; Mohamed, A.; Sahena, F.; Jahurul, M.H.A.; Ghafoor, K.; Norulaini, N.A.N.; Omar, A.K.M. Techniques for extraction of bioactive compounds from plant materials: A review. J. Food Eng. 2013, 117, 426-436. [CrossRef]

104. Safdar, M.N.; Kausar, T.; Jabbar, S.; Mumtaz, A.; Ahad, K.; Saddozai, A.A. Extraction and quantification of polyphenols from kinnow (Citrus reticulate L.) peel using ultrasound and maceration techniques. J. Food Drug Anal. 2017, 25, 488-500. [CrossRef] [PubMed]

105. Kehili, M.; Kammlott, M.; Choura, S.; Zammel, A.; Zetzl, C.; Smirnova, I.; Allouche, N.; Sayadi, S. Supercritical $\mathrm{CO}_{2}$ extraction and antioxidant activity of lycopene and $\beta$-carotene-enriched oleoresin from tomato (Lycopersicum esculentum L.) peels by-product of a Tunisian industry. Food Bioprod. Process. 2017, 102, 340-349. [CrossRef]

106. Anastácio, A.; Silva, R.; Carvalho, I.S. Phenolics extraction from sweet potato peels: Modelling and optimization by response surface modelling and artificial neural network. J. Food Sci. Tech. 2016, 53, 4117-4125. [CrossRef] [PubMed]

107. Alrugaibah, M.; Yagiz, Y.; Gu, L. Use natural deep eutectic solvents as efficient green reagents to extract procyanidins and anthocyanins from cranberry pomace and predictive modeling by RSM and artificial neural networking. Sep. Purifi. Technol. 2021, 255, 117720. [CrossRef]

108. Tongnuanchan, P.; Benjakul, S. Essential oils: Extraction, bioactivities, and their uses for food preservation. J. Food Sci. 2014, 79, R1231-R1249. [CrossRef]

109. Wu, F.; Jin, Y.; Xu, X.; Yang, N. Electrofluidic pretreatment for enhancing essential oil extraction from citrus fruit peel waste. J. Clean. Prod. 2017, 159, 85-94. [CrossRef]

110. Bustamante, J.; van Stempvoort, S.; García-Gallarreta, M.; Houghton, J.A.; Briers, H.K.; Budarin, V.L.; Matharu, A.S.; Clark, J.H. Microwave assisted hydro-distillation of essential oils from wet citrus peel waste. J. Clean. Prod. 2016, 137, 598-605. [CrossRef]

111. Sui, X.; Dong, X.; Zhou, W. Combined effect of $\mathrm{pH}$ and high temperature on the stability and antioxidant capacity of two anthocyanins in aqueous solution. Food Chem. 2014, 163, 163-170. [CrossRef]

112. Nadar, S.S.; Rao, P.; Rathod, V.K. Enzyme assisted extraction of biomolecules as an approach to novel extraction technology: A review. Food Res. Int. 2018, 108, 309-330. [CrossRef]

113. Pojić, M.; Mišan, A.; Tiwari, B. Eco-innovative technologies for extraction of proteins for human consumption from renewable protein sources of plant origin. Trends Food Sci. Tech. 2018, 75, 93-104. [CrossRef]

114. Catalkaya, G.; Kahveci, D. Optimization of enzyme assisted extraction of lycopene from industrial tomato waste. Sep. Purifi. Technol. 2019, 219, 55-63. [CrossRef]

115. Tomaz, I.; Maslov, L.; Stupić, D.; Preiner, D.; Ašperger, D.; Kontić, J.K. Recovery of flavonoids from grape skins by enzyme-assisted extraction. Sep. Sci. Technol. 2016, 51, 255-268. [CrossRef]

116. Zuorro, A.; Lavecchia, R.; González-Delgado, Á.D.; García-Martinez, J.B.; L'Abbate, P. Optimization of enzyme-assisted extraction of flavonoids from corn husks. Processes 2019, 7, 804. [CrossRef]

117. Leyva-López, N.; Valdez-Torres, B.; Delgado-Vargas, F.; García-Estrada, R.S.; Heredia, J.B. Optimized enzyme-aided extraction enhances recovery of carotenoids from tomato peel and improves the biological activity. Int. J. Pharma. Bio. Sci. 2017, 8, 721-727. [CrossRef]

118. Sánchez, A.; Vázquez, A. Bioactive peptides: A review. Food Qual. Saf. 2017, 1, 29-46. [CrossRef]

119. Ngoh, Y.-Y.; Gan, C.-Y. Enzyme-assisted extraction and identification of antioxidative and $\alpha$-amylase inhibitory peptides from Pinto beans (Phaseolus vulgaris cv. Pinto). Food Chem. 2016, 190, 331-337. [CrossRef] 
120. Esteve, C.; Marina, M.; García, M. Novel strategy for the revalorization of olive (Olea europaea) residues based on the extraction of bioactive peptides. Food Chem. 2015, 167, 272-280. [CrossRef]

121. Fuglsang, A.; Rattray, F.P.; Nilsson, D.; Nyborg, N.C. Lactic acid bacteria: Inhibition of angiotensin converting enzyme in vitro and in vivo. Antonie Van Leeuwenhoek. 2003, 83, 27-34. [CrossRef]

122. Karami, Z.; Peighambardoust, S.; Hesari, J.; Akbari-Adergani, B. Response surface methodology to optimize hydrolysis parameters in production of antioxidant peptides from wheat germ protein by alcalase digestion and identification of antioxidant peptides by LC-MS/MS. J. Agric. Sci. Technol. 2019, 21, 829-844.

123. Sonawane, S.K.; Arya, S.S. Citrullus lanatus protein hydrolysate optimization for antioxidant potential. J. Food Meas. Charact. 2017, 11, 1834-1843. [CrossRef]

124. Baş, D.; Boyac1, I.H. Modeling and optimization I: Usability of response surface methodology. J. Food Eng. 2007, 78, 836-845. [CrossRef]

125. Marathe, S.J.; Jadhav, S.B.; Bankar, S.B.; Dubey, K.K.; Singhal, R.S. Improvements in the extraction of bioactive compounds by enzymes. Curr. Opin. Food Sci. 2019, 25, 62-72. [CrossRef]

126. Görgüç, A.; Bircan, C.; Yılmaz, F.M. Sesame bran as an unexploited by-product: Effect of enzyme and ultrasound-assisted extraction on the recovery of protein and antioxidant compounds. Food Chem. 2019, 283, 637-645. [CrossRef] [PubMed]

127. González-García, E.; Marina, M.L.; García, M.C. Plum (Prunus domestica, L.) by-product as a new and cheap source of bioactive peptides: Extraction method and peptides characterization. J. Funct. Food. 2014, 11, 428-437. [CrossRef]

128. Jahanbani, R.; Ghaffari, S.M.; Salami, M.; Vahdati, K.; Sepehri, H.; Sarvestani, N.N.; Sheibani, N.; Moosavi-Movahedi, A.A. Antioxidant and anticancer activities of walnut (Juglans regia L.) protein hydrolysates using different proteases. Plant. Food Hum. Nutr. 2016, 71, 402-409. [CrossRef]

129. Montone, C.M.; Capriotti, A.L.; Cavaliere, C.; La Barbera, G.; Piovesana, S.; Chiozzi, R.Z.; Laganà, A. Characterization of antioxidant and angiotensin-converting enzyme inhibitory peptides derived from cauliflower by-products by multidimensional liquid chromatography and bioinformatics. J. Funct. Food 2018, 44, 40-47. [CrossRef]

130. Thamnarathip, P.; Jangchud, K.; Jangchud, A.; Nitisinprasert, S.; Tadakittisarn, S.; Vardhanabhuti, B. Extraction and characterisation of R iceberry bran protein hydrolysate using enzymatic hydrolysis. Intern. J. Food Sci. Techol. 2016, 51, 194-202. [CrossRef]

131. Sonawane, S.K.; Arya, S.S. Bioactive L. acidissima protein hydrolysates using Box-Behnken design. 3 Biotech 2017, 7, 218. [CrossRef]

132. Yu, Q.; Fan, L.; Li, J. A novel process for asparagus polyphenols utilization by ultrasound assisted adsorption and desorption using resins. Ultrason. Sonochem. 2020, 63, 104920. [CrossRef]

133. Dzah, C.S.; Duan, Y.; Zhang, H.; Wen, C.; Zhang, J.; Chen, G.; Ma, H. The effects of ultrasound assisted extraction on yield, antioxidant, anticancer and antimicrobial activity of polyphenol extracts: A review. Food Biosci. 2020, 35, 100547. [CrossRef]

134. Dzah, C.S.; Duan, Y.; Zhang, H.; Serwah Boateng, N.A.; Ma, H. Latest developments in polyphenol recovery and purification from plant by-products: A review. Trends Food Sci. Tech. 2020, 99, 375-388. [CrossRef]

135. Wang, P.; Cheng, C.; Ma, Y.; Jia, M. Degradation behavior of polyphenols in model aqueous extraction system based on mechanical and sonochemical effects induced by ultrasound. Sep. Purifi. Technol. 2020, 247, 116967. [CrossRef]

136. Grassino, A.N.; Ostojić, J.; Miletić, V.; Djaković, S.; Bosiljkov, T.; Zorić, Z.; Ježek, D.; Rimac Brnčić, S.; Brnčić, M. Application of high hydrostatic pressure and ultrasound-assisted extractions as a novel approach for pectin and polyphenols recovery from tomato peel waste. Innov. Food Sci. Emerg. Technol. 2020, 64, 102424. [CrossRef]

137. Gómez-Mejía, E.; Rosales-Conrado, N.; León-González, M.E.; Madrid, Y. Citrus peels waste as a source of value-added compounds: Extraction and quantification of bioactive polyphenols. Food Chem. 2019, 295, 289-299. [CrossRef]

138. Drosou, C.; Kyriakopoulou, K.; Bimpilas, A.; Tsimogiannis, D.; Krokida, M. A comparative study on different extraction techniques to recover red grape pomace polyphenols from vinification byproducts. Ind. Crop. Prod. 2015, 75, 141-149. [CrossRef]

139. Chmelová, D.; Škulcová, D.; Legerská, B.; Horník, M.; Ondrejovič, M. Ultrasonic-assisted extraction of polyphenols and antioxidants from Picea abies bark. J. Biotechnol. 2020, 314-315, 25-33. [CrossRef] 
140. Wang, L.; Boussetta, N.; Lebovka, N.; Vorobiev, E. Ultrasound assisted purification of polyphenols of apple skins by adsorption/desorption procedure. Ultrason. Sonochem. 2019, 55, 18-24. [CrossRef]

141. Carbone, K.; Amoriello, T.; Iadecola, R. Exploitation of kiwi juice pomace for the recovyer of natural antioxidants through microwave-assisted extraction. Agriculture 2020, 10, 435. [CrossRef]

142. Ballesteros-Vivas, D.; Ortega-Barbosa, J.P.; Sánchez-Camargo, A.D.P.; Rodríguez-Varela, L.I.; Parada-Alfonso, F. Pressurized Liquid Extraction of Bioactives. In Reference Module in Food Science; Elsevier: Berkeley, CA, USA, 2020; pp. 1-15.

143. Wianowska, D.; Gil, M. Critical approach to PLE technique application in the analysis of secondary metabolites in plants. TrAC Trend. Anal. Chem. 2019, 114, 314-325. [CrossRef]

144. Xu, H.; Wang, W.; Liu, X.; Yuan, F.; Gao, Y. Antioxidative phenolics obtained from spent coffee grounds (Coffea arabica L.) by subcritical water extraction. Ind. Crop. Prod. 2015, 76, 946-954. [CrossRef]

145. Santos, D.T.; Veggi, P.C.; Meireles, M.A.A. Optimization and economic evaluation of pressurized liquid extraction of phenolic compounds from jabuticaba skins. J. Food Eng. 2012, 108, 444-452. [CrossRef]

146. Yan, L.; Cao, Y.; Zheng, G. Optimization of subcritical water extraction of phenolic antioxidants from pomegranate (Punica granatum L.) peel by response surface methodology. Anal. Methods 2017, 9, 4647-4656. [CrossRef]

147. He, L.; Zhang, X.; Xu, H.; Xu, C.; Yuan, F.; Knez, Ž.; Novak, Z.; Gao, Y. Subcritical water extraction of phenolic compounds from pomegranate (Punica granatum L.) seed residues and investigation into their antioxidant activities with HPLC-ABTS+ assay. Food Bioprod. Process. 2012, 90, 215-223. [CrossRef]

148. Saravana, P.S.; Getachew, A.T.; Ahmed, R.; Cho, Y.-J.; Lee, Y.-B.; Chun, B.-S. Optimization of phytochemicals production from the ginseng by-products using pressurized hot water: Experimental and dynamic modelling. Biochem. Eng. J. 2016, 113, 141-151. [CrossRef]

149. Plaza, M.; Marina, M.L. Pressurized hot water extraction of bioactives. TrAC Trend. Anal. Chem. 2019, 116, 236-247. [CrossRef]

150. Lin, R.; Cheng, J.; Ding, L.; Song, W.; Qi, F.; Zhou, J.; Cen, K. Subcritical water hydrolysis of rice straw for reducing sugar production with focus on degradation by-products and kinetic analysis. Bioresour. Technol. 2015, 186, 8-14. [CrossRef]

151. Munir, M.T.; Kheirkhah, H.; Baroutian, S.; Quek, S.Y.; Young, B.R. Subcritical water extraction of bioactive compounds from waste onion skin. J. Clean. Prod. 2018, 183, 487-494. [CrossRef]

152. Gilbert-López, B.; Plaza, M.; Mendiola, J.A.; Ibáñez, E.; Herrero, M. Chapter 4-Subcritical water extraction and neoformation of antioxidants. In Water Extraction of Bioactive Compounds; Dominguez González, H., González Muñoz, M.J., Eds.; Elsevier: Berkeley, CA, USA, 2017; pp. 109-130.

153. Chen, Y.-T.; Kao, W.-T.; Lin, K.-W. Effects of pH on the total phenolic compound, antioxidative ability and the stability of dioscorin of various yam cultivars. Food Chem. 2008, 107, 250-257. [CrossRef]

154. Herrero, M.; Mendiola, J.A.; Cifuentes, A.; Ibáñez, E. Supercritical fluid extraction: Recent advances and applications. J. Chromatogr. A. 2010, 1217, 2495-2511. [CrossRef]

155. da Silva, R.P.F.F.; Rocha-Santos, T.A.P.; Duarte, A.C. Supercritical fluid extraction of bioactive compounds. TrAC Trend. Anal. Chem. 2016, 76, 40-51. [CrossRef]

156. Bezerra, F.W.F.; de Oliveira, M.S.; Bezerra, P.N.; Cunha, V.M.B.; Silva, M.P.; da Costa, W.A.; Pinto, R.H.H.; Cordeiro, R.M.; da Cruz, J.N.; Chaves Neto, A.M.J.; et al. Extraction of bioactive compounds. In Green Sustainable Process for Chemical and Environmental Engineering and Science; Inamuddin, A.M., Isloor, A.M., Eds.; Elsevier: Berkeley, CA, USA, 2020; Chapter 8, pp. 149-167.

157. Gallego, R.; Bueno, M.; Herrero, M. Sub-and supercritical fluid extraction of bioactive compounds from plants, food-by-products, seaweeds and microalgae-An update. TrAC Trend. Anal. Chem. 2019, 116, 198-213. [CrossRef]

158. Ndayishimiye, J.; Chun, B.S. Optimization of carotenoids and antioxidant activity of oils obtained from a co-extraction of citrus (Yuzu ichandrin) by-products using supercritical carbon dioxide. Biomass Bioenergy 2017, 106, 1-7. [CrossRef]

159. de Andrade Lima, M.; Charalampopoulos, D.; Chatzifragkou, A. Optimisation and modelling of supercritical $\mathrm{CO}_{2}$ extraction process of carotenoids from carrot peels. J. Supercrit. Fluids 2018, 133, 94-102. [CrossRef]

160. Derrien, M.; Aghabararnejad, M.; Gosselin, A.; Desjardins, Y.; Angers, P.; Boumghar, Y. Optimization of supercritical carbon dioxide extraction of lutein and chlorophyll from spinach by-products using response surface methodology. LWT Food Sci. Technol. 2018, 93, 79-87. [CrossRef] 
161. Kitrytė, V.; Bagdonaite, D.; Rimantas Venskutonis, P. Biorefining of industrial hemp (Cannabis sativa L.) threshing residues into cannabinoid and antioxidant fractions by supercritical carbon dioxide, pressurized liquid and enzyme-assisted extractions. Food Chem. 2018, 267, 420-429. [CrossRef]

162. Piechowiak, T.; Grzelak-Błaszczyk, K.; Bonikowski, R.; Balawejder, M. Optimization of extraction process of antioxidant compounds from yellow onion skin and their use in functional bread production. LWT 2020, 117, 108614. [CrossRef]

163. Gil-Chávez, G.J.; Villa, J.A.; Ayala-Zavala, F.J.; Heredia, J.B.; Sepulveda, D.; Yahia, E.M.; González-Aguilar, G.A. Technologies for extraction and production of bioactive compounds to be used as nutraceuticals and food ingredients: An overview. Compr. Rev. Food. Sci. Food Saf. 2013, 12, 5-23. [CrossRef]

164. Hossain, M.B.; Brunton, N.P.; Patras, A.; Tiwari, B.; O’Donnell, C.P.; Martin-Diana, A.B.; Barry-Ryan, C. Optimization of ultrasound assisted extraction of antioxidant compounds from marjoram (Origanum majorana L.) using response surface methodology. Ultrason. Sonochem. 2012, 19, 582-590. [CrossRef]

165. Mandal, Y.; Mohan, Y.; Hemalatha, S. Microwave assisted extraction-An innovative and promising extraction tool for medicinal plant research. Pharmacogn. Rev. 2007, 1, 7-18.

166. Ajila, C.M.; Brar, S.K.; Verma, M.; Tyagi, R.D.; Godbout, S.; Valéro, J.R. Extraction and analysis of polyphenols: Recent trends. Crit. Rev. Biotechnol. 2011, 31, 227-249. [CrossRef] [PubMed]

167. Halliwell, B.; Gutteridge, J.M. Free Radicals in Biology and Medicine; Halliwell, B., Gutteridge, J.M.C., Eds.; Oxford University Press: Oxford, MS, USA, 2007; Volume 4, pp. 187-267.

168. Circu, M.L.; Aw, T.Y. Reactive oxygen species, cellular redox systems, and apoptosis. Free Radic. Biol. Med. 2010, 48, 749-762. [CrossRef] [PubMed]

169. Pillon, N.J.; Croze, M.L.; Vella, R.E.; Soulère, L.; Lagarde, M.; Soulage, C.O. The lipid peroxidation by-product 4-hydroxy-2-nonenal (4-HNE) induces insulin resistance in skeletal muscle through both carbonyl and oxidative stress. Endocrinology 2012, 153, 2099-2111. [CrossRef] [PubMed]

170. Apak, R.; Özyürek, M.; Güçlü, K.; Çapanoğlu, E. Antioxidant activity/capacity measurement. 1. Classification, physicochemical principles, mechanisms, and electron transfer (ET)-based assays. J. Agric. Food Chem. 2016, 64, 997-1027. [CrossRef] [PubMed]

171. Fraga, C.G.; Galleano, M.; Verstraeten, S.V.; Oteiza, P.I. Basic biochemical mechanisms behind the health benefits of polyphenols. Mol. Aspects Med. 2010, 31, 435-445. [CrossRef]

172. Ighodaro, O.M.; Akinloye, O.A. First line defence antioxidants-superoxide dismutase (SOD), catalase (CAT) and glutathione peroxidase (GPX): Their fundamental role in the entire antioxidant defence grid. Alexandria J. Med. 2018, 54, 287-293. [CrossRef]

173. Tremocoldi, M.A.; Rosalen, P.L.; Franchin, M.; Massarioli, A.P.; Denny, C.; Daiuto, É.R.; Paschoal, J.A.R.; Melo, P.S.; Alencar, S.M.D. Exploration of avocado by-products as natural sources of bioactive compounds. PLoS ONE 2018, 13, e0192577. [CrossRef]

174. Lizárraga-Velázquez, C.E.; Hernández, C.; González-Aguilar, G.A.; Heredia, J.B. Effect of dietary intake of phenolic compounds from mango peel extract on growth, lipid peroxidation and antioxidant enzyme activities in zebrafish (Danio rerio). Lat. Am. J. Aquat. Res. 2019, 47, 602-611. [CrossRef]

175. Reshmitha, T.R.; Thomas, S.; Geethanjali, S.; Arun, K.B.; Nisha, P. DNA and mitochondrial protective effect of lycopene rich tomato (Solanum lycopersicum L.) peel extract prepared by enzyme assisted extraction against $\mathrm{H}_{2} \mathrm{O}_{2}$ induced oxidative damage in L6 myoblasts. J. Funct. Food. 2017, 28, 147-156. [CrossRef]

176. Álvarez, M.V.; Hincapié, S.; Saavedra, N.; Alzate, L.M.; Muñoz, A.M.; Cartagena, C.J.; Londoño-Londoño, J. Exploring feasible sources for lutein production: Food by-products and supercritical fluid extraction, a reasonable combination. Phytochem. Rev. 2015, 14, 891-897. [CrossRef]

177. Chisté, R.C.; Freitas, M.; Mercadante, A.Z.; Fernandes, E. Carotenoids inhibit lipid peroxidation and hemoglobin oxidation, but not the depletion of glutathione induced by ROS in human erythrocytes. Life Sci. 2014, 99, 52-60. [CrossRef] [PubMed]

178. Silva, L.R.; Azevedo, J.; Pereira, M.J.; Valentão, P.; Andrade, P.B. Chemical assessment and antioxidant capacity of pepper (Capsicum annuum L.) seeds. Food Chem. Toxicol. 2013, 53, 240-248. [CrossRef] [PubMed]

179. Alkhalaf, M.I.; Alansari, W.S.; Ibrahim, E.A.; Elhalwagy, M.E.A. Anti-oxidant, anti-inflammatory and anti-cancer activities of avocado (Persea americana) fruit and seed extract. J. King Saud Univ. Sci. 2019, 31, 1358-1362. [CrossRef] 
180. Vivancos, M.; Moreno, J.J. $\beta$-Sitosterol modulates antioxidant enzyme response in RAW 264.7 macrophages. Free Radic. Biol. Med. 2005, 39, 91-97. [CrossRef]

181. Ambigaipalan, P.; Al-Khalifa, A.S.; Shahidi, F. Antioxidant and angiotensin I converting enzyme (ACE) inhibitory activities of date seed protein hydrolysates prepared using Alcalase, Flavourzyme and Thermolysin. J. Funct. Food. 2015, 18, 1125-1137. [CrossRef]

182. García, M.C.; Endermann, J.; González-García, E.; Marina, M.L. HPLC-Q-TOF-MS identification of antioxidant and antihypertensive peptides recovered from cherry (Prunus cerasus L.) subproducts. J. Agric. Food Chem. 2015, 63, 1514-1520. [CrossRef]

183. Rabe, K.; Lehrke, M.; Parhofer, K.G.; Broedl, U.C. Adipokines and insulin resistance. Mol. Med. 2008, 14, 741-751. [CrossRef]

184. International Diabetes Federation. IDF Diabetes Atlas, 9th ed.; Brussels, Belgium, 2019. Available online: https://www.diabetesatlas.org/ (accessed on 19 November 2020).

185. Xiao, J.; Kai, G.; Yamamoto, K.; Chen, X. Advance in dietary polyphenols as $\alpha$-glucosidases inhibitors: A review on structure-activity telationship aspect. Crit. Rev. Food Sci. Nutr. 2013, 53, 818-836. [CrossRef]

186. Medina-Torres, N.; Ayora-Talavera, T.; Espinosa-Andrews, H.; Sanchez-Contreras, A.; Pacheco, N. Ultrasound assisted extraction for the recovery of phenolic compounds from vegetable sources. Agronomy-Basel 2017, 7, 47. [CrossRef]

187. Ameer, K.; Shahbaz, H.M.; Kwon, J.H. Green extraction methods for polyphenols from plant matrices and their byproducts: A review. Compr. Rev. Food. Sci. Food Saf. 2017, 16, 295-315. [CrossRef]

188. Balli, D.; Cecchi, L.; Khatib, M.; Bellumori, M.; Cairone, F.; Carradori, S.; Zengin, G.; Cesa, S.; Innocenti, M.; Mulinacci, N. Characterization of arils juice and peel decoction of fifteen varieties of Punica granatum L.: A focus on anthocyanins, ellagitannins and polysaccharides. Antioxidants 2020, 9, 238. [CrossRef] [PubMed]

189. Ambigaipalan, P.; de Camargo, A.C.; Shahidi, F. Phenolic compounds of pomegranate byproducts (outer skin, mesocarp, divider membrane) and their antioxidant activities. J. Agric. Food Chem. 2016, 64, 6584-6604. [CrossRef] [PubMed]

190. El-Hadary, A.E.; Ramadan, M.F. Phenolic profiles, antihyperglycemic, antihyperlipidemic, and antioxidant properties of pomegranate (Punica granatum) peel extract. J. Food Biochem. 2019, 43, e12803. [CrossRef] [PubMed]

191. Goss, M.J.; Nunes, M.L.O.; Machado, I.D.; Merlin, L.; Macedo, N.B.; Silva, A.M.O.; Bresolin, T.M.B.; Santin, J.R. Peel flour of Passiflora edulis Var. Flavicarpa supplementation prevents the insulin resistance and hepatic steatosis induced by low-fructose-diet in young rats. Biomed. Pharmacother. 2018, 102, 848-854. [CrossRef] [PubMed]

192. Loizzo, M.R.; Lucci, P.; Nunez, O.; Tundis, R.; Balzano, M.; Frega, N.G.; Conte, L.; Moret, S.; Filatova, D.; Moyano, E.; et al. Native colombian fruits and their by-products: Phenolic profile, antioxidant activity and hypoglycaemic potential. Foods 2019, 8, 89. [CrossRef] [PubMed]

193. Arruda, H.S.; Pereira, G.A.; de Morais, D.R.; Eberlin, M.N.; Pastore, G.M. Determination of free, esterified, glycosylated and insoluble-bound phenolics composition in the edible part of araticum fruit (Annona crassiflora Mart.) and its by-products by HPLC-ESI-MS/MS. Food Chem. 2018, 245, 738-749. [CrossRef]

194. Rakariyatham, K.; Liu, X.Y.; Liu, Z.Y.; Wu, S.F.; Shahidi, F.; Zhou, D.Y.; Zhu, B.W. Improvement of phenolic contents and antioxidant activities of longan (Dimocarpus longan) peel extracts by enzymatic treatment. Waste Biomass Valoriz. 2020, 11, 3987-4002. [CrossRef]

195. Carullo, G.; Spizzirri, U.G.; Loizzo, M.R.; Leporini, M.; Sicari, V.; Aiello, F.; Restuccia, D. Valorization of red grape (Vitis vinifera cv. Sangiovese) pomase as functional food ingredient. Ital. J. Food Sci. 2020, 32, 367-385. [CrossRef]

196. Ferri, M.; Bin, S.; Vallini, V.; Fava, F.; Michelini, E.; Roda, A.; Minnucci, G.; Bucchi, G.; Tassoni, A. Recovery of polyphenols from red grape pomace and assessment of their antioxidant and anti-cholesterol activities. New Biotech. 2016, 33, 338-344. [CrossRef]

197. Kadouh, H.C.; Sun, S.; Zhu, W.J.; Zhou, K.Q. alpha-Glucosidase inhibiting activity and bioactive compounds of six red wine grape pomace extracts. J. Funct. Food. 2016, 26, 577-584. [CrossRef]

198. Kilic, I.H.; Sarikurkcu, C.; Karagoz, I.D.; Uren, M.C.; Kocak, M.S.; Cilkiz, M.; Tepe, B. A significant by-product of the industrial processing of pistachios: Shell skin-RP-HPLC analysis, and antioxidant and enzyme inhibitory activities of the methanol extracts of Pistacia vera L. Shell skins cultivated in Gaziantep, Turkey. RSC Adv. 2016, 6, 1203-1209. [CrossRef] 
199. Lavelli, V.; Harsha, P.; Ferranti, P.; Scarafoni, A.; Iametti, S. Grape skin phenolics as inhibitors of mammalian alpha-glucosidase and alpha-amylase-effect of food matrix and processing on efficacy. Food Funct. 2016, 7, 1655-1663. [CrossRef] [PubMed]

200. Zhang, L.; Tu, Z.-C.; Xie, X.; Wang, H.; Wang, H.; Wang, Z.-X.; Sha, X.-M.; Lu, Y. Jackfruit (Artocarpus heterophyllus Lam.) peel: A better source of antioxidants and a-glucosidase inhibitors than pulp, flake and seed, and phytochemical profile by HPLC-QTOF-MS/MS. Food Chem. 2017, 234, 303-313. [CrossRef] [PubMed]

201. Islam, M.R.; Haque, A.R.; Kabir, M.R.; Hasan, M.M.; Khushe, K.J.; Hasan, S.M.K. Fruit by-products: The potential natural sources of antioxidants and alpha-glucosidase inhibitors. J. Food Sci. Technol.-Mysore 2020, 1-12. [CrossRef]

202. Henriquez, C.; Sarkar, D.; Molina, J.; Sepulveda, S.; Cordova, A.; Saavedra, J.; Shetty, K. Improving antioxidant and anti-hyperglycemic activity in cereal and apple-based food formulations using bioactive ingredients from apple peel. J. Food Process Preserv. 2020, 44, 1-11. [CrossRef]

203. Oboh, G.; Ademiluyi, A.O.; Akinyemi, A.J.; Henle, T.; Saliu, J.A.; Schwarzenbolz, U. Inhibitory effect of polyphenol-rich extracts of jute leaf (Corchorus olitorius) on key enzyme linked to type 2 diabetes ( $\alpha$-amylase and $\alpha$-glucosidase) and hypertension (angiotensin I converting) in vitro. J. Funct. Food. 2012, 4, 450-458. [CrossRef]

204. Lim, S.M.; Loh, S.P. In vitro antioxidant capacities and antidiabetic properties of phenolic extracts from selected citrus peels. Int. Food Res. J. 2016, 23, 211-219.

205. Ling, Y.; Shi, Z.; Yang, X.L.; Cai, Z.W.; Wang, L.X.; Wu, X.M.; Ye, A.Q.; Jiang, J.P. Hypolipidemic effect of pure total flavonoids from peel of Citrus (PTFC) on hamsters of hyperlipidemia and its potential mechanism. Exp. Gerontol. 2020, 130, 110786. [CrossRef]

206. Toomer, O.T.; Vu, T.; Pereira, M.; Williams, K. Dietary supplementation with peanut skin polyphenolic extracts (PSPE) reduces hepatic lipid and glycogen stores in mice fed an atherogenic diet. J. Funct. Food. 2019, 55, 362-370. [CrossRef]

207. Quideau, S.; Deffieux, D.; Douat-Casassus, C.; Pouységu, L. Plant polyphenols: Chemical properties, biological activities, and synthesis. Angew. Chem. Int. Ed. 2011, 50, 586-621. [CrossRef]

208. Bandyopadhyay, P.; Ghosh, A.K.; Ghosh, C. Recent developments on polyphenol-protein interactions: Effects on tea and coffee taste, antioxidant properties and the digestive system. Food Funct. 2012, 3, 592-605. [CrossRef] [PubMed]

209. de la Garza, A.L.; Milagro, F.I.; Boque, N.; Campión, J.; Martínez, J.A. Natural inhibitors of pancreatic lipase as new players in obesity treatment. Planta Med. 2011, 77, 773-785. [CrossRef] [PubMed]

210. Velderrain-Rodriguez, G.R.; Palafox-Carlos, H.; Wall-Medrano, A.; Ayala-Zavala, J.F.; Chen, C.Y.O.; Robles-Sanchez, M.; Astiazaran-Garcia, H.; Alvarez-Parrilla, E.; Gonzalez-Aguilar, G.A. Phenolic compounds: Their journey after intake. Food Funct. 2014, 5, 189-197. [CrossRef] [PubMed]

211. Halliwell, B.; Gutteridge, J.M.C. Reactive species in disease: Friends or foes? In Free Radicals in Biology and Medicine; Halliwell, B., Gutteridge, J.M.C., Eds.; Oxford University Press: Oxford, UK, 2015; pp. 511-638.

212. Zhang, T.; Li, M.; Fu, X.; Mou, H. Purification and charicterization of angiotensin I-converting enzyme (ACE) inhibitory peptides with specific structure X-Pro. Eur. Food Res. Technol. 2019, 245, 1743-1753. [CrossRef]

213. Turner, J.M.; Kodali, R. Should angiotensin-converting enzyme inhibitors ever be used for the management of hypertension? Curr. Cardiol. Rep. 2020, 22, 95. [CrossRef]

214. Liu, R.L.; Ge, X.L.; Gao, X.Y.; Zhan, H.Y.; Shi, T.; Su, N.; Zhang, Z.Q. Two angiotensin-converting enzyme-inhibitory peptides from almond protein and the protective action on vascular endothelial function. Food Funct. 2016, 7, 3733-3739. [CrossRef]

215. Gu, X.; Hou, Y.-K.; Li, D.; Wang, J.-Z.; Wang, F.-J. Separation, purification, and identification of angiotensin I-converting enzyme inhibitory peptides from walnut (Juglans regia L.) hydrolyzate. Int. J. Food Prop. 2015, 18, 266-276. [CrossRef]

216. He, R.; Malomo, S.A.; Alashi, A.; Girgih, A.T.; Ju, X.; Aluko, R.E. Purification and hypotensive activity of rapeseed protein-derived renin and angiotensin converting enzyme inhibitory peptides. J. Funct. Food. 2013, 5, 781-789. [CrossRef]

217. He, R.; Malomo, S.A.; Girgih, A.T.; Ju, X.; Aluko, R.E. Glycinyl-histidinyl-serine (GHS), a novel rapeseed protein-derived peptide has blood pressure-lowering effect in spontaneously hypertensive rats. J. Agric. Food Chem. 2013, 61, 8396-8402. [CrossRef] 
218. Xu, Y.; Bao, T.; Han, W.; Chen, W.; Zheng, X.; Wang, J. Purification and identification of an angiotensin I-converting enzyme inhibitory peptide from cauliflower by-products protein hydrolysate. Process Biochem. 2016, 51, 1299-1305. [CrossRef]

219. Montone, C.M.; Zenezini Chiozzi, R.; Marchetti, N.; Cerrato, A.; Antonelli, M.; Capriotti, A.L.; Cavaliere, C.; Piovesana, S.; Laganà, A. Peptidomic approach for the identification of peptides with potential antioxidant and anti-hyperthensive effects derived from asparagus by-products. Molecules 2019, 24,3627. [CrossRef] [PubMed]

220. Vásquez-Villanueva, R.; Muñoz-Moreno, L.; Carmena, M.J.; Marina, M.L.; García, M.C. In vitro antitumor and hypotensive activity of peptides from olive seeds. J. Funct. Food. 2018, 42, 177-184. [CrossRef]

221. Zou, Z.; Wang, M.; Wang, Z.; Aluko, R.E.; He, R. Antihypertensive and antioxidant activities of enzymatic wheat bran protein hydrolysates. J. Food Biochem. 2020, 44, e13090. [CrossRef] [PubMed]

222. Pinciroli, M.; Aphalo, P.; Nardo, A.E.; Añón, M.C.; Quiroga, A.V. Broken rice as a potential functional ingredient with inhibitory activity of renin and angiotensin-converting enzyme (ACE). Plant Food Hum. Nutr. 2019, 74, 405-413. [CrossRef]

223. Chirinos, R.; Pedreschi, R.; Velásquez-Sánchez, M.; Aguilar-Galvez, A.; Campos, D. In vitro antioxidant and angiotensin I-converting enzyme inhibitory properties of enzymatically hydrolyzed quinoa (Chenopodium quinoa) and kiwicha (Amaranthus caudatus) proteins. Cereal Chem. 2020, 97, 949-957. [CrossRef]

224. Connolly, A.; O’Keeffe, M.B.; Piggott, C.O.; Nongonierma, A.B.; FitzGerald, R.J. Generation and identification of angiotensin converting enzyme (ACE) inhibitory peptides from a brewers' spent grain protein isolate. Food Chem. 2015, 176, 64-71. [CrossRef]

225. Betancur-Ancona, D.; Dávila-Ortiz, G.; Chel-Guerrero, L.A.; Torruco-Uco, J.G. ACE-I inhibitory activity from Phaseolus lunatus and Phaseolus vulgaris peptide fractions obtained by ultrafiltration. J. Med. Food 2015, 18, 1247-1254. [CrossRef]

226. Shi, A.; Liu, H.; Liu, L.; Hu, H.; Wang, Q.; Adhikari, B. Isolation, purification and molecular mechanism of a peanut protein-derived ACE-inhibitory peptide. PLoS ONE 2014, 9, e111188. [CrossRef]

227. Valenzuela-García, P.; Bobadilla, N.A.; Ramírez-González, V.; León-Villanueva, A.; Lares-Asseff, I.A.; Valdez-Ortiz, A.; Medina-Godoy, S. Antihypertensive effect of protein hydrolysate from azufrado beans in spontaneously hypertensive rats. Cereal Chem. 2017, 94, 117-123. [CrossRef]

228. Bleakley, S.; Hayes, M.; O'Shea, N.; Gallagher, E.; Lafarga, T. Predicted release and analysis of novel ACE-I, renin, and DPP-IV inhibitory peptides from common oat (Avena sativa) protein hydrolysates using in silico analysis. Foods 2017, 6, 108. [CrossRef]

229. Muniraj, N.; Siddharth, S.; Sharma, D. Bioactive compounds: Multi-targeting silver bullets for preventing and treating breast cancer. Cancers 2019, 11, 1563. [CrossRef] [PubMed]

230. Pfeffer, C.M.; Singh, A.T.K. Apoptosis: A target for anticancer therapy. Int. J. Mol. Sci. 2018, $19,448$. [CrossRef] [PubMed]

231. Nair, P.; Lu, M.; Petersen, S.; Ashkenazi, A. Chapter Five-Apoptosis initiation through the cell-extrinsic pathway. In Methods in Enzymology; Ashkenazi, A., Yuan, J., Wells, J.A., Eds.; Academic Press: Cambridge, MA, USA, 2014; Volume 544, pp. 99-128.

232. Shi, J.-H.; Sun, S.-C. Tumor necrosis factor receptor-associated factor regulation of nuclear factor $\mathrm{kB}$ and mitogen-activated protein kinase pathways. Front. Immunol. 2018, 9. [CrossRef] [PubMed]

233. Otto, T.; Sicinski, P. Cell cycle proteins as promising targets in cancer therapy. Nat. Rev. Cancer 2017, 17, 93-115. [CrossRef] [PubMed]

234. Pan, Z.; Zhang, X.; Yu, P.; Chen, X.; Lu, P.; Li, M.; Liu, X.; Li, Z.; Wei, F.; Wang, K.; et al. Cinobufagin induces cell cycle arrest at the G2/M phase and promotes apoptosis in malignant melanoma cells. Front. Oncol. 2019, 9, 853. [CrossRef] [PubMed]

235. Lugano, R.; Ramachandran, M.; Dimberg, A. Tumor angiogenesis: Causes, consequences, challenges and opportunities. Cell. Mol. Life Sci. 2020, 77, 1745-1770. [CrossRef] [PubMed]

236. Quintero-Fabián, S.; Arreola, R.; Becerril-Villanueva, E.; Torres-Romero, J.C.; Arana-Argáez, V.; Lara-Riegos, J.; Ramírez-Camacho, M.A.; Alvarez-Sánchez, M.E. Role of matrix metalloproteinases in angiogenesis and cancer. Front. Oncol. 2019, 9, 1370. [CrossRef]

237. Cathcart, J.; Pulkoski-Gross, A.; Cao, J. Targeting metalloproteinases in cancer: Bringing new life to old ideas. Genes Dis. 2015, 2, 26-34. [CrossRef] 
238. Menon, D.B.; Gopalakrishnan, V. Terpenoids isolated from the shoot of Plectranthus hadiensis induces apoptosis in human colon cancer cells via the mitochondria-dependent pathway. Nutr. Cancer 2015, 67, 697-705. [CrossRef]

239. Lee, J.-H.; Lee, K.; Lee, D.H.; Shin, S.Y.; Yong, Y.; Lee, Y.H. Anti-invasive effect of $\beta$-myrcene, a component of the essential oil from Pinus koraiensis cones, in metastatic MDA-MB-231 human breast cancer cells. J. Korean Soc. Appl. Biol. Chem. 2015, 58, 563-569. [CrossRef]

240. Spyridopoulou, K.; Tiptiri-Kourpeti, A.; Lampri, E.; Fitsiou, E.; Vasileiadis, S.; Vamvakias, M.; Bardouki, H.; Goussia, A.; Malamou-Mitsi, V.; Panayiotidis, M.I. Dietary mastic oil extracted from Pistacia lentiscus var. chia suppresses tumor growth in experimental colon cancer models. Sci. Rep. 2017, 7, 1-14. [CrossRef] [PubMed]

241. Bae, H.; Song, G.; Lim, W. Stigmasterol causes ovarian cancer cell apoptosis by inducing endoplasmic reticulum and mitochondrial dysfunction. Pharmaceutics 2020, 12, 488. [CrossRef] [PubMed]

242. Kangsamaksin, T.; Chaithongyot, S.; Wootthichairangsan, C.; Hanchaina, R.; Tangshewinsirikul, C.; Svasti, J. Lupeol and stigmasterol suppress tumor angiogenesis and inhibit cholangiocarcinoma growth in mice via downregulation of tumor necrosis factor- $\alpha$. PLoS ONE 2017, 12, e0189628. [CrossRef] [PubMed]

243. Alvarez-Sala, A.; Attanzio, A.; Tesoriere, L.; Garcia-Llatas, G.; Barberá, R.; Cilla, A. Apoptotic effect of a phytosterol-ingredient and its main phytosterol ( $\beta$-sitosterol) in human cancer cell lines. Int. J. Food Sci. Nutr. 2019, 70, 323-334. [CrossRef] [PubMed]

244. Farahmandfar, R.; Esmaeilzadeh Kenari, R.; Asnaashari, M.; Shahrampour, D.; Bakhshandeh, T. Bioactive compounds, antioxidant and antimicrobial activities of Arum maculatum leaves extracts as affected by various solvents and extraction methods. Food Sci. Nutr. 2019, 7, 465-475. [CrossRef] [PubMed]

245. Shashirekha, M.N.; Mallikarjuna, S.E.; Rajarathnam, S. Status of bioactive compounds in foods, with focus on fruits and vegetables. Crit. Rev. Food Sci. Nutr. 2015, 55, 1324-1339. [CrossRef]

246. Górniak, I.; Bartoszewski, R.; Króliczewski, J. Comprehensive review of antimicrobial activities of plant flavonoids. Phytochem. Rev. 2019, 18, 241-272. [CrossRef]

247. Adamczak, A.; Ożarowski, M.; Karpiński, T.M. Antibacterial activity of some flavonoids and organic acids widely distributed in plants. J. Clin. Med. 2019, 9, 109. [CrossRef]

248. Lampe, J.W. Spicing up a vegetarian diet: Chemopreventive effects of phytochemicals. Am. J. Clin. Nutr. 2003, 78, 579S-583S. [CrossRef]

249. Mujeeb, F.; Bajpai, P.; Pathak, N. Phytochemical evaluation, antimicrobial activity, and determination of bioactive components from leaves of Aegle marmelos. BioMed Res. Int. 2014, 2014, 497606. [CrossRef]

250. Wahyudha, D.; Mardawati, E.; Setyowati, E.; Dahlan, A.; Balia, R. The comparative study of the fruit and leaf extract of Ficuslyrata Warb on antibacterial activities. IOP Conf. Ser. Mater. Sci. Eng. 2018, 420, 012077. [CrossRef]

251. Khan, M.I.; Kim, J.-D.; Shin, J. Green tea seed isolated saponins exerts antibacterial effects against various strains of Gram positive and Gram negative bacteria, a comprehensive study in vitro and in vivo. Evid-Based Compl. Alt. Med. 2019, 2018, 3486106. [CrossRef] [PubMed]

252. Xie, Y.; Chen, J.; Xiao, A.; Liu, L. Antibacterial activity of polyphenols: Structure-activity relationship and influence of hyperglycemic condition. Molecules 2017, 22, 1913. [CrossRef] [PubMed]

253. Taguri, T.; Tanaka, T.; Kouno, I. Antimicrobial activity of 10 different plant polyphenols against bacteria causing food-borne disease. Biol. Pharm. Bull. 2004, 27, 1965-1969. [CrossRef] [PubMed]

254. Ozkan, G.; Sagdic, O.; Baydar, N.; Kurumahmutoglu, Z. Antibacterial activities and total phenolic contents of grape pomace extracts. J. Sci. Food Agric. 2004, 84, 1807-1811. [CrossRef]

255. Yi, S.-M.; Zhu, J.-L.; Fu, L.-L.; Li, J.-R. Tea polyphenols inhibit Pseudomonas aeruginosa through damage to the cell membrane. Int. J. Food Microbiol. 2010, 144, 111-117. [CrossRef]

256. Adnan, S.-N.-A.; Ibrahim, N.; Yaacob, W.A. Disruption of methicillin-resistant Staphylococcus aureus protein synthesis by tannins. Germs 2017, 7, 186-192. [CrossRef]

257. Steinmann, J.; Buer, J.; Pietschmann, T.; Steinmann, E. Anti-infective properties of epigallocatechin-3-gallate (EGCG), a component of green tea. Br. J. Pharmacol. 2012, 168, 1059-1073. [CrossRef]

258. Yoda, Y.; Hu, Z.-Q.; Shimamura, T.; Zhao, W.-H. Different susceptibilities of Staphylococcus and Gram-negative rods to epigallocatechin gallate. J. Infect. Chemother. 2004, 10, 55-58. [CrossRef] 
259. Bouarab-Chibane, L.; Forquet, V.; Lantéri, P.; Clément, Y.; Léonard-Akkari, L.; Oulahal, N.; Degraeve, P.; Bordes, C. Antibacterial properties of polyphenols: Characterization and QSAR (quantitative structure-activity relationship) models. Front. Microbiol. 2019, 10, 829. [CrossRef]

260. Wu, T.; He, M.; Zang, X.; Zhou, Y.; Qiu, T.; Pan, S.; Xu, X. A structure-activity relationship study of flavonoids as inhibitors of E. Coli by membrane interaction effect. Biochim. Biophys. Acta Biomembr. 2013, 1828, 2751-2756. [CrossRef] [PubMed]

261. Phan, H.T.T.; Yoda, T.; Chahal, B.; Morita, M.; Takagi, M.; Vestergaard, M.d.C. Structure-dependent interactions of polyphenols with a biomimetic membrane system. Biochim. Biophys. Acta Biomembr. 2014, 1838, 2670-2677. [CrossRef] [PubMed]

262. Yu, X.; Chu, S.; Hagerman, A.; Lorigan, G. Probing the interaction of polyphenols with lipid bilayers by solid-state NMR spectroscopy. J. Agric. Food Chem. 2011, 59, 6783-6789. [CrossRef] [PubMed]

263. Nakayama, M.; Shimatani, K.; Ozawa, T.; Shigemune, N.; Tomiyama, D.; Yui, K.; Katsuki, M.; Ikeda, K.; Nonaka, A.; Miyamoto, T. Mechanism for the antibacterial action of epigallocatechin gallate (EGCg) on Bacillus subtilis. Biosci. Biotechnol. Biochem. 2015, 79, 845-854. [CrossRef]

264. Gordon, N.C.; Wareham, D.W. Antimicrobial activity of the green tea polyphenol (-)-epigallocatechin-3-gallate (EGCG) against clinical isolates of Stenotrophomonas maltophilia. Int. J. Antimicrob. Ag. 2010, 36, 129-131. [CrossRef]

265. Cherubin, P.; Garcia, M.C.; Curtis, D.; Britt, C.B.T.; Craft, J.W., Jr.; Burress, H.; Berndt, C.; Reddy, S.; Guyette, J.; Zheng, T.; et al. Inhibition of cholera toxin and other AB toxins by polyphenolic compounds. PLoS ONE 2016, 11, e0166477. [CrossRef]

266. Castillo, S.; Heredia, N.; García, S. 2(5H)-Furanone, epigallocatechin gallate, and a citric-based disinfectant disturb quorum-sensing activity and reduce motility and biofilm formation of Campylobacter jejuni. Folia Microbiol. 2015, 60, 89-95. [CrossRef]

267. Parvez, A.K.; Saha, K.; Rahman, J.; Munmun, R.A.; Rahman, A.; Dey, S.K.; Rahman, S.; Islam, S.; Shariare, M.H. Antibacterial activities of green tea crude extracts and synergistic effects of epigallocatechingallate (EGCG) with gentamicin against MDR pathogens. Heliyon 2019, 5, e02126. [CrossRef]

268. Matsumoto, Y.; Kaihatsu, K.; Nishino, K.; Ogawa, M.; Kato, N.; Yamaguchi, A. Antibacterial and antifungal activities of new acylated derivatives of epigallocatechin gallate. Front. Microbiol. 2012, 16, 53. [CrossRef]

269. Jeon, J.; Kim, J.H.; Lee, C.K.; Oh, C.H.; Song, H.J. The antimicrobial activity of epigallocatehin-3-gallate and green tea extracts against Pseudomonas aeruginosa and Escherichia coli isolated from skin wounds. Ann. Dermatol. 2014, 26, 564-569. [CrossRef]

270. Hosseinzadeh, S.; Saei, H.D.; Ahmadi, M.; Salehi, T.Z. Antimicrobial effect of licochalcone A and epigallocatechin-3-gallate against Salmonella typhimurium isolated from poultry flocks. Iran. J. Microbiol. 2018, 10, 51-58. [CrossRef] [PubMed]

271. Moreno-Vásquez, M.J.; Valenzuela-Buitimea, E.L.; Plascencia-Jatomea, M.; Encinas-Encinas, J.C.; Rodríguez-Félix, F.; Sánchez-Valdes, S.; Rosas-Burgos, E.C.; Ocaño-Higuera, V.M.; Graciano-Verdugo, A.Z. Functionalization of chitosan by a free radical reaction: Characterization, antioxidant and antibacterial potential. Carbohydr. Polym. 2017, 155, 117-127. [CrossRef] [PubMed]

272. Lagha, A.B.; Haas, B.; Grenier, D. Tea polyphenols inhibit the growth and virulence properties of Fusobacterium nucleatum. Sci. Rep. 2017, 7, 44815. [CrossRef] [PubMed]

273. Lagha, A.B.; Groeger, S.; Meyle, J.; Grenier, D. Green tea polyphenols enhance gingival keratinocyte integrity and protect against invasion by Porphyromonas gingivalis. Pathog. Dis. 2018, 76. [CrossRef]

274. Quiñones, B.; Massey, S.; Friedman, M.; Swimley, M.S.; Teter, K. Novel cell-based method to detect Shiga toxin 2 from Escherichia coli O157:H7 and inhibitors of toxin activity. Appl. Environ. Microbiol. 2009, 75, 1410-1416. [CrossRef]

275. Yadav, D.; Kumar, A.; Kumar, P.; Mishra, D. Antimicrobial properties of black grape (Vitis vinifera L.) peel extracts against antibiotic-resistant pathogenic bacteria and toxin producing molds. Indian J. Pharmacol. 2015, 47, 663-667. [CrossRef]

276. Reddy, S.; Taylor, M.; Zhao, M.; Cherubin, P.; Geden, S.; Ray, S.; Francis, D.; Teter, K. Grape extracts inhibit multiple events in the cell biology of cholera intoxication. PLOS ONE 2013, 8, e73390. [CrossRef]

277. Li, X.; He, C.; Song, L.; Li, T.; Cui, S.; Zhang, L.; Jia, Y. Antimicrobial activity and mechanism of Larch bark procyanidins against Staphylococcus aureus. Acta Biochim. Biophys. Sin. 2017, 49, 1058-1066. [CrossRef] 
278. Biancalani, C.; Cerboneschi, M.; Tadini-Buoninsegni, F.; Campo, M.; Scardigli, A.; Romani, A.; Tegli, S. Global analysis of type three secretion system and quorum sensing inhibition of Pseudomonas savastanoi by polyphenols extracts from vegetable residues. PLoS ONE 2016, 11, e0163357. [CrossRef]

279. Rémy, B.; Mion, S.; Plener, L.; Elias, M.; Chabrière, E.; Daudé, D. Interference in bacterial quorum sensing: A biopharmaceutical perspective. Front. Pharmacol. 2018, 9, 203. [CrossRef]

280. Zhu, J.; Huang, X.; Zhang, F.; Feng, L.; Li, J. Inhibition of quorum sensing, biofilm, and spoilage potential in Shewanella baltica by green tea polyphenols. J. Microbiol. 2015, 53, 829-836. [CrossRef] [PubMed]

281. Liu, W.; Lu, H.; Chu, X.; Lou, T.; Zhang, N.; Zhang, B.; Chu, W. Tea polyphenols inhibits biofilm formation, attenuates the quorum sensing-controlled virulence and enhances resistance to Klebsiella pneumoniae infection in Caenorhabditis elegans model. Microb. Pathog. 2020, 147, 104266. [CrossRef] [PubMed]

282. Mostafa, I.; Abbas, H.A.; Ashour, M.L.; Yasri, A.; El-Shazly, A.M.; Wink, M.; Sobeh, M. Polyphenols from Salix tetrasperma impair virulence and inhibit quorum sensing of Pseudomonas aeruginosa. Molecules 2020, 25, 1341. [CrossRef]

283. Yin, H.; Yifeng, D.; Wang, H.; Liu, W.; Zhuang, X.; Chu, W. Tea polyphenols as an antivirulence compound disrupt quorum-sensing regulated pathogenicity of Pseudomonas aeruginosa. Sci. Rep. 2015, 5, 16158. [CrossRef] [PubMed]

284. Carraro, L.; Fasolato, L.; Montemurro, F.; Martino, M.E.; Balzan, S.; Servili, M.; Novelli, E.; Cardazzo, B. Polyphenols from olive mill waste affect biofilm formation and motility in Escherichia coli K-12. Microb. Biotechnol. 2014, 7, 265-275. [CrossRef] [PubMed]

285. Defoirdt, T.; Pande, G.S.J.; Baruah, K.; Bossier, P. The apparent quorum-sensing inhibitory activity of pyrogallol is a side effect of peroxide production. Antimicrob. Agents Chemother. 2013, 57, 2870-2873. [CrossRef]

286. Fan, W.-W.; Yuan, G.-Q.; Li, Q.-q.; Lin, W. Antibacterial mechanisms of methyl gallate against Ralstonia solanacearum. Australas. Plant Pathol. 2014, 43, 1-7. [CrossRef]

287. Hossain, M.A.; Park, N.-H.; Mechesso, A.F.; Birhanu, B.; Kang, J.; Reza, M.A.; Suh, J.-W.; Park, S.-C. Impact of phenolic compounds in the acyl homoserine lactone-mediated quorum sensing regulatory pathways. Sci. Rep. 2017, 7, 10618. [CrossRef]

288. Westfall, S.; Lomis, N.; Prakash, S. A novel polyphenolic prebiotic and probiotic formulation have synergistic effects on the gut microbiota influencing Drosophila melanogaster physiology. Artif. Cells Nanomed. Biotechnol. 2018, 46, 1-15. [CrossRef]

289. Duda-Chodak, A.; Tarko, T.; Satora, P.; Sroka, P. Interaction of dietary compounds, especially polyphenols, with the intestinal microbiota: A review. Eur. J. Nutr. 2015, 54, 325-341. [CrossRef]

290. Kawabata, K.; Mukai, R.; Ishisaka, A. Quercetin and related polyphenols: New insights and implications for their bioactivity and bioavailability. Food Funct. 2015, 6, 1399-1417. [CrossRef] [PubMed]

Publisher's Note: MDPI stays neutral with regard to jurisdictional claims in published maps and institutional affiliations.

(C) 2020 by the authors. Licensee MDPI, Basel, Switzerland. This article is an open access article distributed under the terms and conditions of the Creative Commons Attribution (CC BY) license (http://creativecommons.org/licenses/by/4.0/). 